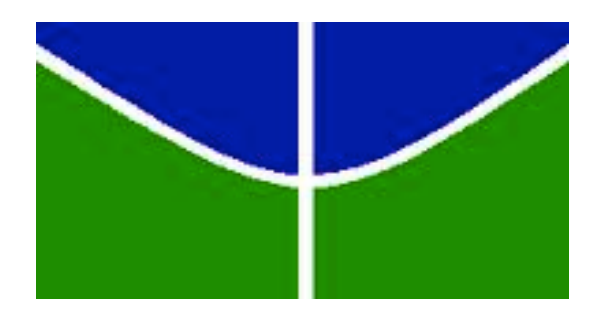

UNIVERSIDADE DE BRASÍLIA

FACULDADE DE CIÊNCIA DA INFORMAÇÃO

PROGRAMA DE PÓS-GRADUAÇÃO EM CIÊNCIA DA INFORMAÇÃO

ANA FLÁVIA LUCAS DE FARIA KAMA

\title{
LIVROS, BIBLIOTECAS UNIVERSITÁRIAS E LIVROS ELETRÔNICOS: ASPECTOS E CONSEQUÊNCIAS DE UM NOVO SUPORTE DA ESCRITA
}




\section{LIVROS, BIBLIOTECAS UNIVERSITÁRIAS E LIVROS ELETRÔNICOS: ASPECTOS E CONSEQUENCIAS DE UM NOVO SUPORTE DA ESCRITA}

Dissertação apresentada ao Programa de Pós-Graduação em Ciência da Informação da Universidade de Brasília - UnB, como requisito parcial para obtenção do título de Mestre em Ciência da Informação.

Orientadora: Prof ${ }^{\mathrm{a}}$. Dra ${ }^{\mathrm{a}}$. Miriam Paula Manini

Área de concentração: Organização da Informação 
K15a Kama, Ana Flávia Lucas de Faria.

Livros, bibliotecas universitárias e livros eletrônicos: aspectos e consequências de um novo suporte da escrita / Ana Flávia Lucas de Faria Kama. - Brasília, 2016.

122 f. : il. ; color.

Orientadora: Professora Doutora Miriam Paula Manini

Dissertação (Mestrado) - Universidade de Brasília, Faculdade de Ciência da Informação, 2016.

1. Livro. 2. E-book. 3. Livro eletrônico. 4. Biblioteca universitária. 5. Livro digital. I. Título. 


\section{FOLHA DE APROVAÇÃO}

Título: "Livros, bibliotecas universitárias e livros eletrônicos: aspectos e consequências de um novo suporte da escrita".

\section{Autor (a): Ana Flávia Lucas de Faria Kama}

Área de concentração: Gestão da Informação

Linha de pesquisa: Comunicação e Mediação da Informação

Dissertação submetida à Comissão Examinadora designada pelo Colegiado do Programa de Pósgraduação em Ciência da Informação da Faculdade em Ciência da Informação da Universidade de Brasília como requisito parcial para obtenção do título de Mestre em Ciência da Informação.

Brasília, 29 de abril de 2016.

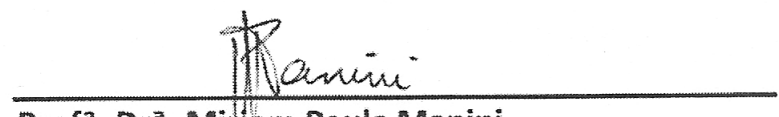

Profa. Dra. Mirlam Paula Manini

Presidente (UnB/PPGCINF)

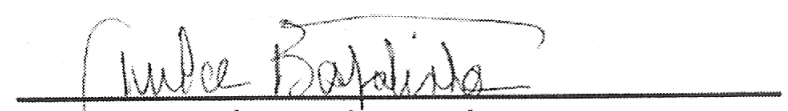

Profa. Dra. Dulce Maria Bapstista

Membro Titular (UnB/PPGCINF)

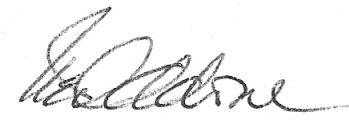

Profe. Dra. Nanci Elizabeth Oddone

Membro Titular (UNIRIO)

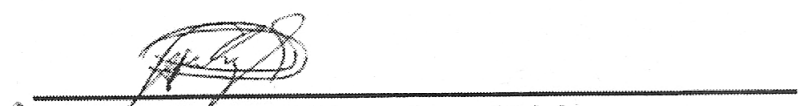

\footnotetext{
Prof. br. Raphael Diego Greenhalgh

Membro Suplente (UnB/BCE)
}

Edificio da Biblioteca Centra: (BCE) - Entrada Leste - Campus Universitảio Darcy Ribeiro - Asa Norte - Brasilia, DF CEP 70910-900 - Tel.: +55 (61) 3107-2632 - Telefax: +55 (61) 3107-2633 - E-mail: pqcinf(unb.br 


\section{Agradecimentos}

Agradeço à professora Miriam Paula Manini por me receber na orientação dessa pesquisa com empenho, dedicação e curiosidade em cada detalhe sobre o mundo dos livros digitais; sua ajuda com a revisão na literatura, conhecimento sobre livros e seu apoio emocional. Agradeço aos professores da graduação em Biblioteconomia que me instigaram com o amor e dedicação aos livros, dentre eles Dulce Baptista e Sebastião de Souza. Agradeço também aos professores Fernando Leite e Fernanda Moreno pela grande iluminação nos caminhos tortuosos da metodologia científica, assim como à professora Sely Costa por compartilhar tanta dedicação e conhecimento sobre a Ciência da Informação em suas aulas.

Agradecimentos fraternos e biblioteconômicos cheios de carinho aos meus queridos e inesquecíveis amigos de curso, da turma do segundo semestre de 2006. Não seria possível ter chegado aqui sem a motivação e admiração desses companheiros de curso: Fabiane, Yaciara, Tainá, Jonniery, Mariana e Vivianne. Vocês são minha inspiração.

Agradeço aos meus colegas de Banco que me ensinaram muito do que sei sobre coleguismo e respeito mútuo, por ter tido a oportunidade de compartilhar de meus momentos mais felizes e gratificantes; em especial, aos colegas Franco, Têka, Socorro, Eduardo, Fabi e Wall.

Com muita ternura agradeço à minha segunda família escolhida a dedo, meus queridos amigos. A conquista de cada um é a minha; que essa seja a de vocês também. Em especial, agradeço à Raquel, à Ana Carolina, à Raíssa, à Marília e a toda Abarilândia.

Ao companheiro e amigo de quase uma década, Luiz, agradeço o amor, o carinho, o apoio, as revisões, os debates, as sugestões e o companheirismo necessário aos meus dias.

Com amor agradeço à minha família, que acreditou em mim e no meu potencial desde muito, quando nem mesmo eu acreditava; em especial, à minha Madrinha Paré, meu pai, minha irmã, tias e primas queridas. Sem o seu apoio, nada poderia ser realizado. 


\section{Epígrafe}

"Este livro tem poros. Tem feições. Este livro poderia passar pelo microscópio. Você encontraria vida sob a lâmina, emanando em profusão infinita. Quanto mais poros, quanto mais detalhes de vida fielmente gravados por centímetro quadrado você conseguir captar numa folha de papel, mais 'literário' você será. Pelo menos, esta é a minha definição. Detalhes reveladores. Detalhes frescos. $O s$ bons escritores quase sempre tocam a vida. Os mediocres apenas passam e a deixam para as moscas. Entende agora por que os livros são odiados e temidos? Eles mostram os poros no rosto da vida."

(Fahrenheit 451. Ray Bradbury) 


\section{Resumo}

Analisa a gestão e o uso do livro eletrônico pelas bibliotecas universitárias do Distrito Federal. O livro eletrônico é o resultado da última revolução da história do livro: a digital. Desde a década de quarenta do século XX esse tipo de livro vem sendo debatido e estudado, em especial pelas bibliotecas universitárias. Entretanto, em pleno ano de 2016, o Brasil não possui um conceito legal de livro eletrônico, assim como não há um consenso exato sobre a definição desse tipo de livro na área acadêmico-científica da Ciência da Informação, o que é refletido na forma como as Bibliotecas Universitárias gerem suas coleções de livros eletrônicos. O presente estudo analisa o histórico do livro e do livro eletrônico, assim como as diversas definições dadas na literatura da área de Ciência da Informação para o livro eletrônico. Para alcançar o objetivo geral, foi realizada uma pesquisa de campo nas bibliotecas universitárias do DF com uma abordagem metodológica mista e de cunho descritivo. $\mathrm{O}$ instrumento de coleta utilizado foi o questionário. A coleta foi realizada entre novembro de 2015 e fevereiro de 2016, em um total de 14 questionários respondidos. Os resultados mostram que ainda não há um consenso sobre a definição de livro eletrônico na literatura da área, na legislação nacional nem dentro das políticas das bibliotecas universitárias pesquisadas. Foi constatado que o livro eletrônico já é uma realidade nos acervos das bibliotecas universitárias e que os bibliotecários dão valor a esse tipo de documento. As conclusões indicam que os estudos sobre o livro eletrônico precisam ser mais coesos e interligados com a literatura especializada da área e com os avanços legislativos no Congresso Nacional sobre o tema. Mesmo o livro eletrônico sendo um elemento importante no acervo das bibliotecas universitárias, ainda não existem políticas específicas que gerenciem sua compra, seleção, disponibilização, preservação e continuidade dentro dos acervos dessas instituições.

Palavras-chave: Livro. E-book. Livro eletrônico. Livro digital. Biblioteca universitária. 


\begin{abstract}
This study analyses the use and management of digital books by academic libraries in the Brazilian Federal District. Digital books are the result of the latest revolution in the history of publications: the digital revolution. Since the 1940's this variety of book has been particularly studied and debated by academic libraries. However, in the heart of the year 2016, Brazil has not yet devised a legal concept of the digital book, nor reached a clear legal consensus on the definition of this type of media in the Information Science scientific-academic field, which is reflected on the way academic libraries manage their collections. In this study, the history of books and digital books is analyzed, as well as the concepts regarding the digital book in the literature within the Information Science field. In order to reach this project's main objective a field research was carried out in the academic libraries of the Brazilian Federal District. The research presented a mixed methodological approach with a descriptive intent. The tool used for the research was a questionnaire. Data collection was conducted between November 2015 and February 2016 and 14 questionnaires were answered. Results indicate that a consensus has not been reached on the definitions given to electronic books within the field's literature, Brazilian legislation, and the policies from the libraries that took part in the research. Also, it has been found that the presence of electronic books is a reality in the academic libraries collections and that librarians value this type of document. The implications of these results indicate that studies on electronic books should be more unified and intertwined with the specialized literature in the field and the legislative advances in the Brazilian National Congress on the topic. Despite being an important element in academic libraries collections, the electronic book lacks specific policies that manage their acquisition, selection, availability, preservation and continuity inside the collections in those institutions.
\end{abstract}

Keywords: Books. E-book. Electronic book. Digital book. Academic Library. 


\section{Listas de figuras}

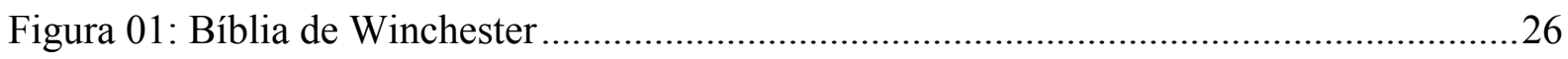

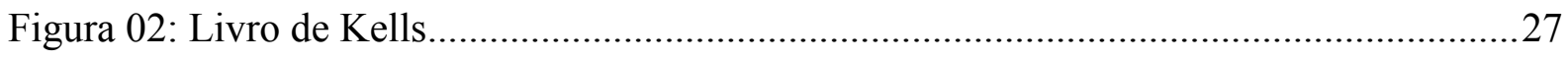

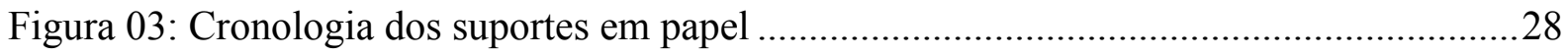

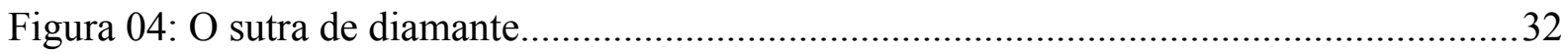

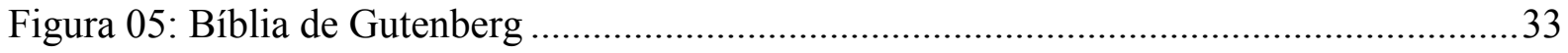

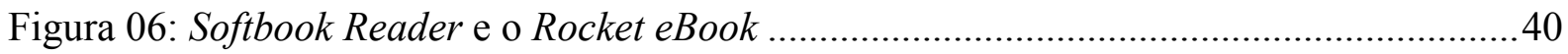

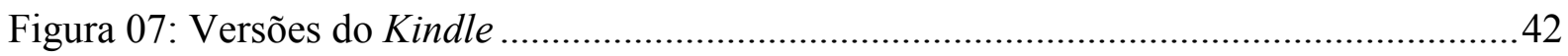

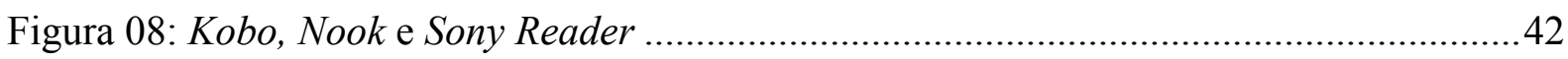




\section{Lista de tabelas}

Tabela 01: Lista das Instituições de Ensino Superior (IES) em funcionamento no DF .67

Tabela 02: Lista das bibliotecas que responderam ao questionário. 


\section{Listas de quadros}

Quadro 01: Definições de livro eletrônico 61

Quadro 02: Tramitação do Projeto de Lei 4534/2012 ...........................................................64

Quadro 03: Relação dos objetivos específicos com os blocos de questões do questionário ....72

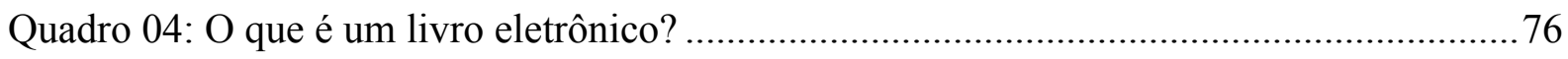

Quadro 05: Definições de livro eletrônico por categorias ......................................................78

Quadro 06: Dados sobre acesso e uso dos livros eletrônicos pelas bibliotecas universitárias .92 Quadro 07: Qual a importância dos livros eletrônicos para a biblioteca universitária. 94

Quadro 08: Vantagens do uso do livro eletrônico para os usuários de bibliotecas universitárias

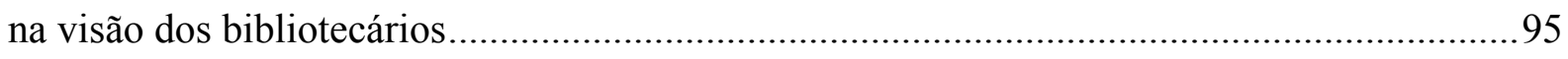

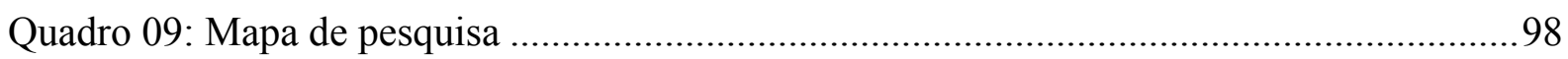




\section{Lista de gráficos}

Gráfico 01: Idade do bibliotecário

Gráfico 02: Gênero do bibliotecário

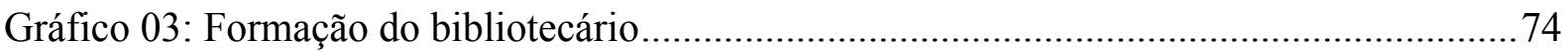

Gráfico 04: Um livro impresso quando digitalizado é um livro eletrônico? ............................74

Gráfico 05: Quais formatos de livro eletrônico o bibliotecário conhece.................................74

Gráfico 06: Existe diferença entre livro eletrônico e livro digital? .........................................75

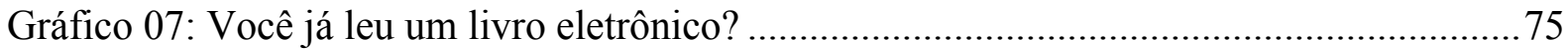

Gráfico 08: Você já adquiriu um livro eletrônico em uma livraria? .........................................75

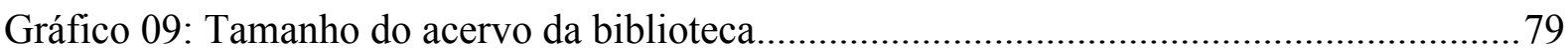

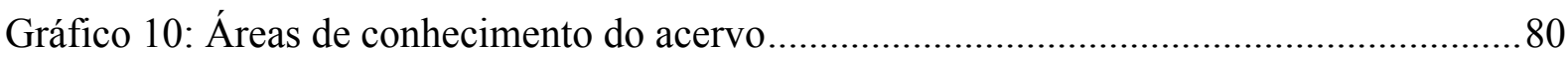

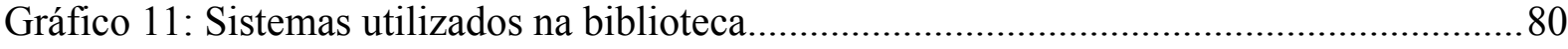

Gráfico 12: Número de terminais disponíveis na biblioteca .................................................. 81

Gráfico 13: Número de usuários por mês da biblioteca ….................................................... 81

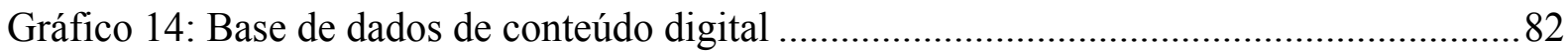

Gráfico 15: Quantos terminais de consulta com acesso a livros eletrônicos ou acervo digital

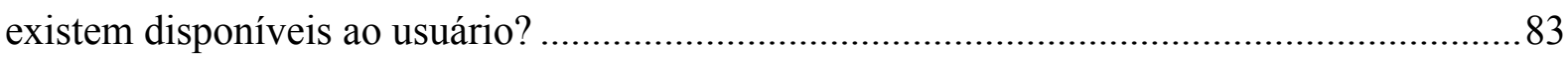

Gráfico 16: Há quanto tempo a biblioteca possui uma coleção de livros eletrônicos..............83

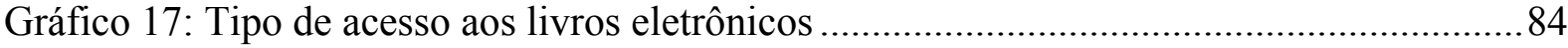

Gráfico 18: Base de dados que não são da biblioteca e disponibilizam livros eletrônicos de acesso aberto

Gráfico 19: Base de dados que não são da biblioteca e disponibilizam livros eletrônicos de

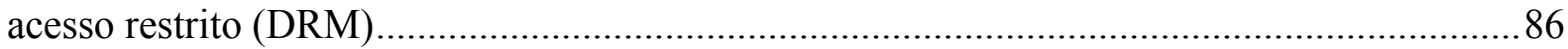

Gráfico 20: Empréstimo dos livros eletrônicos de acesso restrito.............................................87

Gráfico 21: Tipologias e formatos de livros eletrônicos que a biblioteca disponibiliza aos usuários

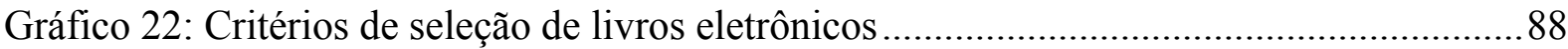

Gráfico 23: Divulgação dos livros eletrônicos na biblioteca..................................................... 89

Gráfico 24: Porcentagem de uso de livros eletrônicos existentes na biblioteca

Gráfico 25: Maiores dificuldades encontradas pela biblioteca na formação do acervo de livros eletrônicos 


\section{Lista de abreviaturas e siglas}

CI - Ciência da Informação

CONARQ - Conselho Nacional de Arquivos

DF - Distrito Federal

DRM - Digital rights management ou gestão de direitos digitais

IBICT - Instituto Brasileiro de Informação em Ciência e Tecnologia

IES - Instituições de Ensino Superior

LDE - Livro digital e eletrônico

MEC - Ministério da Educação

PL - Projeto de Lei

SINAES - Sistema Nacional de Avaliação da Educação Superior

SOC - Sistemas de Organização do Conhecimento 


\section{Sumário}

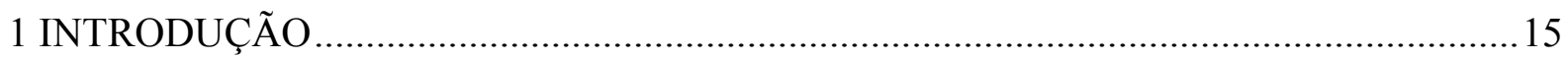

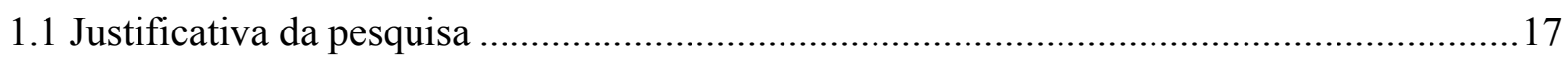

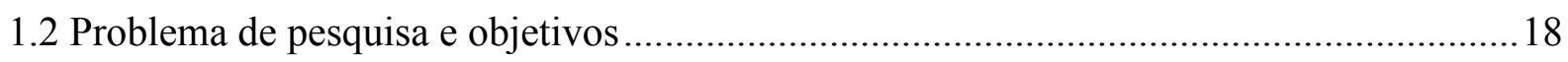

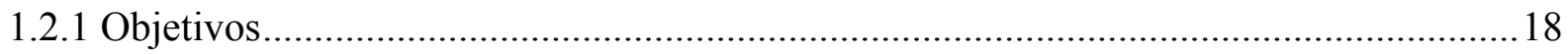

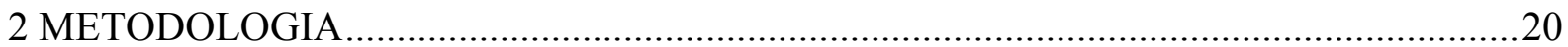

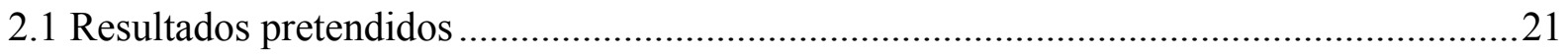

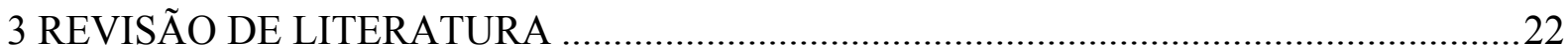

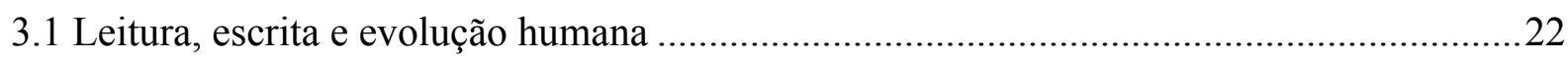

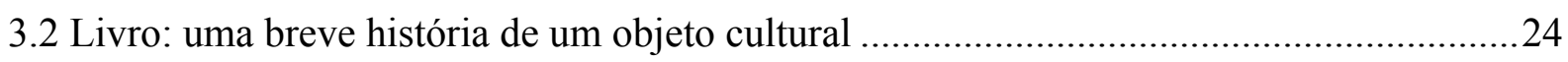

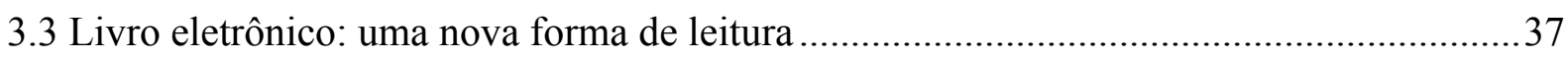

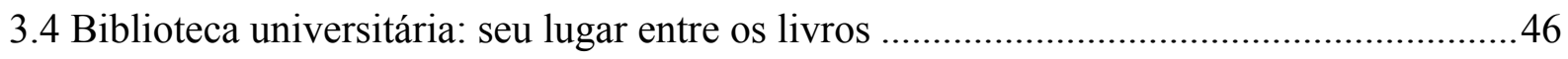

3.5 Ciência da Informação e o contexto do livro impresso ao livro eletrônico.........................53

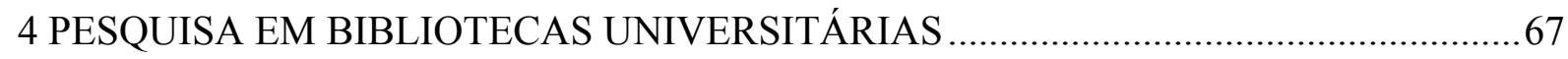

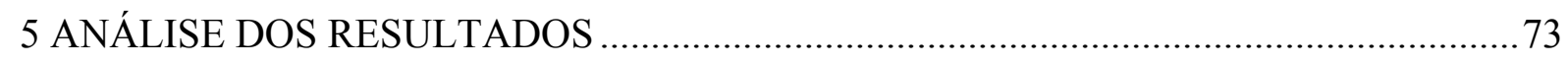

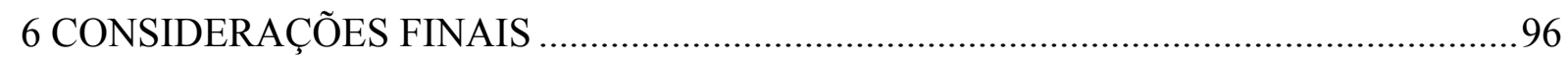

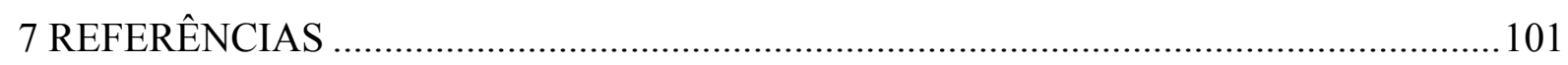

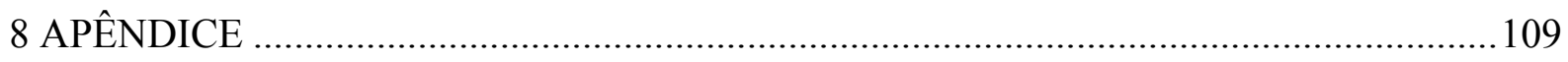

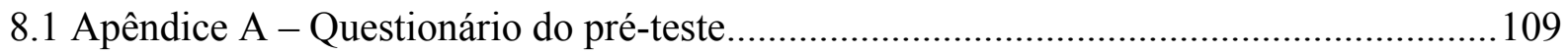

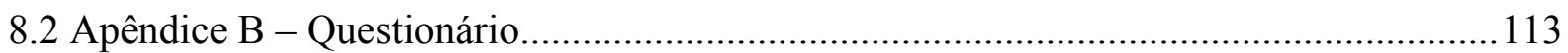




\section{INTRODUÇÃO}

A primeira ideia de livro eletrônico ${ }^{1}$ de que se tem notícia é o Memex, criado em 1945 pelo pesquisador estadunidense Dr. Vannevar Bush. Bush desenvolveu o que chamava de "a primeira máquina de leitura", que conseguiria abrigar uma grande quantidade de informações. Porém, só nos anos 2000 é que os e-readers, equipamentos leitores de livros eletrônicos tornaram-se mais populares e permitiram a consolidação de sua comercialização. Em contrapartida, o livro impresso é o objeto de leitura mais eficaz de que se tem notícia, vide sua hegemonia nos últimos cinco séculos.

Chega-se então a uma época em que os dois objetos coexistem e precisam de definição e tratamento específicos. Atualmente muito se fala da dicotomia entre um e outro, e de um possível fim do livro. Porém, pouco se pesquisa no ambiente acadêmico, principal responsável pela produção de conhecimento e, portanto, um dos maiores promotores e consumidores de objetos de leitura, sobre uma possível substituição do livro pelos livros eletrônicos. Segundo Cunha (2010), o último não tomará o lugar do primeiro, haverá o nicho para o livro impresso e para o eletrônico, e aos poucos as bibliotecas irão se adaptar à demanda e necessidades de ambos. Porém, o próprio conceito de biblioteca traz em sua origem a ideia da guarda de livro - e aqui se diz do livro em si, livro físico - do "papel para escrever" (ARAÚJO, 1986). A história da guarda dos livros se mistura à história da leitura, e a forma como seu acesso poderá mudar nos próximos anos deve ser acompanhada de perto pela Ciência da Informação.

Em uma perspectiva mais conceitual, o livro enquanto objeto possui seus fins desde sua gênese - e aqui se pode entender sua formação a partir do momento em que houve a junção de tábuas de madeira, pergaminho ou papel em formato de códex ${ }^{2}$ - não podendo ser conceituado puramente, a não ser por faculdades culturais humanas, que podem ser definidas como juízo estético, o que englobaria uma infinidade de experiências e intenções de julgamento do objeto livro (KANT, 2008). Portanto, toda a conceituação acerca do livro é uma representação de um juízo individual permeado por intenções, que, por ser representativo, transcende seu significado inicial "puro", tornando-o qualquer coisa que

\footnotetext{
${ }^{1}$ O termo "livro eletrônico" foi escolhido para ser utilizado nesse trabalho para se referir ao tipo de publicação digital, que se assemelha ao livro físico, atualmente conhecida no mercado e na área acadêmica como e-book ou electronic book. No item 3.3, páginas 39-40, haverá um esclarecimento técnico e acadêmico acerca dos termos "livro eletrônico" e "livro digital".

${ }^{2}$ Codex ou códice, segundo Cunha e Cavalcanti $(2008$, p. 88$)$, seria o "livro antigo, manuscrito, anterior à invenção da imprensa (circa 1450), formado com folhas de pergaminho ou papiro e de valor histórico ou literário. No códice, ao contrário dos rolos de papiro, as folhas estavam reunidas como nos livros atuais". É a primeira vez que a forma do livro, como a conhecemos hoje, aparece na história.
} 
dialogue com o objetivo de seu definidor. Logo, um livro eletrônico não pode ser classificado como livro sem que haja a conscientização de sua representação enquanto um juízo estético. Da mesma maneira, uma biblioteca não pode permanecer em seu conceito de outrora após a inclusão dos livros eletrônicos em seu acervo e no cotidiano dos usuários.

McGarry (1999, p. 11) afirma que "A informação deve ser ordenada, estruturada ou contida de alguma forma, senão permanecerá amorfa e inutilizável”, e é a partir desse pressuposto que o conceito de livro e de livro eletrônico devem ser discutidos, para então se iniciar a tarefa da organização e da coexistência dos dois em um ambiente bibliotecário. Os profissionais da informação também precisam tomar para si a tarefa de entender esse novo cenário do impresso e do digital. Dados de uma pesquisa encomendada pelo Sindicato Nacional dos Editores de Livros e pela Câmara Brasileira do Livro sobre a evolução do mercado de livros eletrônicos no Brasil (CARRENHO, 2013) mostram que a venda de livros digitais no país, em 2012, representou menos de $2 \%$ das vendas editoriais totais nacionais; porém, esse dado demonstra um aumento de mais de 300\% das vendas em relação ao ano anterior, 2011. Portanto, há uma realidade cada vez mais forte sobre a inserção dos livros eletrônicos no consumo de leitura do brasileiro.

Essa realidade não se encontra apenas na esfera comercial e de entretenimento do Brasil e do mundo mas também na acadêmica. Darnton (2010) defende que os livros eletrônicos podem salvar a publicação acadêmica e o declínio das edições universitárias de monografias, o qual se observa com certa preocupação nas últimas décadas; sem que para isso houvesse uma substituição de um pelo outro, apenas um "como um suplemento, e não substituto, da grande máquina de Gutenberg” (DARNTON, 2010, p. 95).

Portanto, esse cenário já chegou ao contexto acadêmico, mais especificamente às bibliotecas universitárias. Não há como essas unidades de informação ficarem de fora do debate, já que são o "centro intelectual do campus" (CUNHA, 2000) e as principais agregadoras do conhecimento científico do país. Observa-se a necessidade latente de que essas unidades de informação iniciem um grande processo de debate interno e entre elas, para não servirem de alvo das decisões do mercado de fornecimento de livros eletrônicos, mas para serem precursoras da tomada de decisão.

A presente dissertação foi dividida em oito capítulos. O primeiro trata da introdução ao tema da pesquisa, sua justificativa, problema e objetivos. Em seguida, o capítulo dois traz a metodologia utilizada no estudo que busca atender aos objetivos propostos. 
O capítulo três mostra o embasamento teórico do estudo a partir da revisão de literatura sobre o livro impresso e sua história, com o intuito de entender como o conceito e as funcionalidades tecnológicas e históricas do livro chegaram até o século XXI, por meio do delineamento das revoluções pelas quais passou. A importância da leitura e da escrita para o cenário de formação do mundo manuscrito e impresso do livro também são tratadas na primeira parte da revisão de literatura. A seguir é feito um levantamento sobre a última revolução da história do livro, a virtual, que culminou com avanços tecnológicos que deram formato ao que hoje é conhecido como livro eletrônico. A papel da biblioteca universitária na formação intelectual e informacional do país e sua importância no estudo de livros eletrônicos também é delineada na quarta parte da revisão. Por final, segue-se um histórico e um embasamento teórico da Ciência da Informação no estudo do livro impresso e do livro eletrônico, seguindo para seus conceitos conhecidos na literatura da área assim como a progressão de sua definição dentro da legislação brasileira, ainda em tramitação no Congresso Nacional.

Os capítulos quatro e cinco demonstram o processo de pesquisa de campo com as bibliotecas universitárias do DF selecionadas na amostra. De 69 Instituições de Ensino Superior (IES) listadas no site do MEC, 47 foram confirmadas em funcionamento via internet ou telefone, gerando um número de 14 respostas ao método de coleta de dados - questionário -, o que significou $34,15 \%$ de respostas - a amostra do estudo. No decorrer do capítulo são analisadas as respostas fechadas e quantitativas ao questionário, assim como suas respostas abertas e qualitativas.

A seguir, o capítulo seis delineia as considerações finais do estudo e mostra o mapa de pesquisa da dissertação, indicando o objetivo geral e os específicos e seu progresso durante o estudo. Algumas propostas de estudos futuros são sugeridas assim como são apontadas as limitações da pesquisa.

\subsection{Justificativa da pesquisa}

A busca pela solução do problema dessa proposta de pesquisa está embasada na lógica (teorias) e em evidências (observação), ou seja, há revisão de literatura da área e sua discussão, assim como coleta de dados por meio de questionários aplicados em profissionais envolvidos com livros e livros eletrônicos em bibliotecas universitárias. 
A pesquisa levará em conta quais métodos científicos serão mais apropriados para que a solução do problema em questão seja investigada e/ou alcançada, podendo, deste modo, readaptar esses métodos ou escolher novos, mais adequados ao problema da pesquisa.

Além disso, a proposta pretende pesquisar um fenômeno dentro do escopo da Ciência da Informação que não possui uma ampla gama de estudos acadêmicos, com pouca discussão teórica e sistemática sobre a dicotomia conceitual entre livros e livros eletrônicos. Em busca feita no portal da Biblioteca Digital de Teses e Dissertações em fevereiro de 2014, foram localizadas apenas três dissertações sobre os temas "livro eletrônico" ou "e-book", o que corrobora esse argumento.

Do ponto de vista epistemológico, esse estudo tem a intenção de dar embasamento teórico e científico para a tomada de decisão eficiente entre os envolvidos no meio político e cultural relacionados ao acesso/disponibilidade de livros e livros eletrônicos em bibliotecas universitárias. Tem o intuito de caracterizar, por meio de revisão de teorias e de conceitos clássicos e modernos, a interação dos usuários/leitores com a dicotomia ou complementaridade entre livros e livros eletrônicos.

As interações cotidianas entre o leitor, a biblioteca, os livros e os livros eletrônicos não estão bem definidas. O resultado do novo conceito de leitura eletrônica/portátil versus física/portátil precisa ser estudado para que novas políticas e práticas de leitura sejam melhor embasadas em literatura científica. As novas interações e relacionamentos do leitor com esse novo cenário, concomitante entre o físico e o digital, ainda não foram exaustivamente estudadas e observadas nas bibliotecas universitárias e na relação de construção da memória literária dos povos.

O impacto que novas bibliotecas desprovidas de livros físicos pode ter no imaginário do leitor, assim como em seu hábito de leitura, necessita de pesquisas sistematizadas para que uma nova teoria e planejamento de leitura e acesso à informação possam ser consolidados.

\subsection{Problema de pesquisa e objetivos}

De que maneira as bibliotecas universitárias do Distrito Federal estão gerindo os livros eletrônicos (e-books) em suas coleções?

\subsubsection{Objetivos}

\section{Objetivo geral}


Analisar como é feita a gestão e o uso de livros eletrônicos (e-books) nas coleções das bibliotecas universitárias do Distrito Federal.

\section{Objetivos específicos}

1. Identificar os principais conceitos de livro impresso e livro eletrônico na literatura e traçar um comparativo entre eles;

2. Mapear quais bibliotecas universitárias do DF possuem coleções de livros eletrônicos;

3. Identificar como os bibliotecários das bibliotecas universitárias do DF conceituam e definem livros eletrônicos;

4. Apontar como os livros eletrônicos estão sendo geridos e utilizados pelas bibliotecas universitárias do DF. 


\section{METODOLOGIA}

Este estudo possui um caráter descritivo. Investiga os aspectos essenciais dos fenômenos em questão, quais sejam: os conceitos relevantes de livro eletrônico e impresso na literatura da área e sua atual inserção nas bibliotecas universitárias do Distrito Federal (SERAKAN, 2003). A pesquisa tem uma abordagem metodológica mista e se desenvolve através da coleta de dados por meio de aplicação de questionário aos bibliotecários das bibliotecas selecionadas na amostra, com questões fechadas e abertas. Portanto, esta pesquisa busca maior diversidade de tipos de dados com o intuito de proporcionar uma melhor visão do problema de pesquisa proposto (CRESWELL, 2010).

A pesquisa envolve um problema atual, com foco na comunidade de bibliotecas universitárias do DF e visa a analisar um problema específico que pode subsidiar a resolução de deficiências quanto ao acesso e disponibilidade de livros eletrônicos; sob este aspecto, constitui-se em uma pesquisa aplicada (KAUARK; MANHÃES; MEDEIROS, 2010).

O objetivo dessa pesquisa não é analisar uma relação de causa e efeito, no contexto do problema proposto; logo, não é necessário que se manipule as variáveis do fenômeno estudado. Elas são apenas observadas, coletadas e interpretadas. Desta forma, o ambiente de estudo é o natural (SERAKAN, 2003; KOTHARI, 2004). O trabalho pretende responder o problema de pesquisa em apenas um momento específico, ou seja, não haverá a retomada posterior, em outro período ou data, na coleta de dados e análise dos fenômenos pesquisados no estudo. Logo, o horizonte temporal é o transversal, cross-sectional ou one-shot (SERAKAN, 2003).

O método de pesquisa adotado é o misto sequencial. Esse é um dos procedimentos utilizados no tipo de abordagem mista, a qual, como dito antes, foi realizada nesse estudo. $\mathrm{O}$ método escolhido foi aplicado sequencialmente, com o intuito de um dar suporte teórico e informativo ao outro (CRESWELL, 2010). O método consiste em:

- Levantamento de dados: são levantados dados acerca da amostra escolhida, por meio de questionários.

Desta forma, a técnica utilizada para a coleta de dados é o questionário.

O questionário foi aplicado na amostra selecionada com questões fechadas e abertas, com o intuito de obter dados relevantes aos objetivos específicos da pesquisa. Ele foi escolhido pelo fato de ser uma forma eficaz e consolidada de obtenção de dados, além de permitir uma maior flexibilização por parte dos respondentes no que tange ao seu preenchimento. 
A análise dos dados quantitativos foi feita por meio de estatística simples em uma amostra intencional.

Creswell (2010) afirma que a coleta e análise dos dados qualitativos pode ser realizada ao mesmo tempo, ou seja, a primeira dando suporte para interpretações da segunda. A análise dos dados foi feita por meio da categorização das respostas abertas do questionário. Elas foram tabuladas e comparadas posteriormente.

Os dados obtidos nesse estudo passaram por um processo de validação, por meio da estratégia da triangulação. Houve comparação das respostas dos questionários entre si, que buscou gerar um meio de validar temas e conceitos respondidos pela amostra (CRESWELL, 2010).

\subsection{Resultados pretendidos}

1. Diferenciação entre os conceitos de livro e de livro eletrônico;

2. Identificação do principal conceito de livro eletrônico utilizado pelas bibliotecas universitárias do DF;

3. Identificação e caracterização das coleções de livros eletrônicos em bibliotecas universitárias do DF. 


\section{REVISÃO DE LITERATURA}

\subsection{Leitura, escrita e evolução humana}

O ser humano é uma das espécies mais interessantes da natureza. O que o diferencia dos outros animais é o que o torna mais potente. Essa potência, segundo Laraia (2007), é a capacidade do humano de fabricar instrumentos que colaboram para a eficiência de sua sobrevivência biológica e a comunicação oral. Entretanto, o que mais o singulariza é sua capacidade exclusiva de possuir cultura; ou seja, é impossível se pensar em ser humano sem pensar em sua produção cultural.

O conceito de cultura pode ser muito vasto e prolífico; logo, faz-se necessário ater-se a uma de suas mais unânimes explicações, que seria o desenvolvimento humano da linguagem, da comunicação e de seus costumes. Tal explicação enseja a ideia de que a história humana é um contínuo processo de acumulação do conhecimento e de sua retroalimentação (LARAIA, 2007). A explicação para esse constante cenário seria a descoberta e utilização massiva do ser humano de sua capacidade de comunicação.

Muitas são as formas de uso da comunicação humana, e a primeira delas foi a comunicação pelos gestos, por sinais. Antes mesmo dos humanos da pré-história perceberem que era possível organizar fonemas e, a partir deles, formar palavras com múltiplos significados, eram os gestos e os sons sem definição que os faziam se entenderem. A partir disso, e decorrente de um longo processo evolutivo de seleção natural, a linguagem fonética foi-se configurando entre os humanos, tornando-os cada vez mais seres culturais.

Foi na Grécia antiga que a dicotomia entre fala e escrita se fez, e moldou, a partir de então, a forma como a produção intelectual do ocidente se deu até hoje. Os filósofos présocráticos, e até mesmo Sócrates, tinham como crença a ideia de que a fala levava à verdade. A polis grega era pautada em acordos e interações orais e toda a estrutura social desse povo tinha como base a fala. Julgava-se que, para atestar a veracidade de uma informação, era necessário ouvir seu oponente ou orador; não havia a ideia burocrática do registro escrito. Segundo McNeely e Wolverton (2013, p. 27), "a palavra escrita, em contraste, não merece confiança e é corruptora, porque está separada das ações, da honra do caráter de quem quer que a tenha expressado"; era esse o pensamento dos contemporâneos a Sócrates.

Entretanto, dentre os alunos socráticos, Platão surge com um novo pensamento, o de que a escrita poderia agrupar doutrinas filosóficas distintas e permitir a análise de suas semelhanças e diferenças. Nesse momento é a fala que é vista como uma ferramenta tênue de construção do pensamento, ou seja, um "argumento poderia prosseguir indefinidamente em 
torno das mesmas questões; a escrita torna possível, e desejável, uma abordagem inclusiva, ecumênica" (McNEELY; WOLVERTON, 2013, p. 29). Após Platão, foi Aristóteles quem ratificou a ideia da escrita como o meio essencial do pensamento humano filosófico. Os debates e ideias começam a ser registrados e a escrita é legitimada como uma forma premente do processo contínuo da construção do pensamento. É a partir dessa ideia que a biblioteca de Alexandria, por exemplo, surge como um sonho de Demétrio e dos Ptolomeus na era antiga. É apenas com a escrita que se pode entender o processo de leitura.

Como consequência dessa evolução da comunicação e da linguagem humana, dois grandes fenômenos comunicativos ganham destaque: a escrita e a leitura. Nem sempre a leitura pôde estar atrelada à escrita registrada que conhecemos hoje. As duas nascem muito próximas, entretanto não dependentes entre si. Manguel (1997) afirma que a leitura é uma capacidade intrínseca do ser humano, bastando que este se proponha a ler para então já saber que possuía tal capacidade. O que é necessário, sim, é um treinamento com os símbolos e os sinais, capacidade essa que toda pessoa pode ter.

A leitura seria a junção de três etapas, quais sejam: ver, decifrar e ler (MANGUEL, 1997). Essa tríade corrobora o conceito que Laraia (2007) expõe em seu texto, ao afirmar a imprescindibilidade da cultura para a formação humana. A parte de decifrar a informação, seja ela escrita ou desenhada, não existe sem a utilização das experiências cotidianas, históricas e emocionais que a pessoa possui ao ler algo. Tal decifração passa também pela ativação de todas as memórias físicas e intelectuais que são realizadas no momento em que ela absorve ou apreende uma nova informação. Logo, o ato de ler seria "ver a palavra e levála em consideração" (MANGUEL, 1997, p. 51).

A leitura, portanto, contribuiu e contribui para a evolução da humanidade, no sentido de fazê-la alçar voos tecnológicos e emocionais que talvez não seriam possíveis sem a ativação constante da capacidade cognitiva e sensorial humanas. É a partir do momento em que a leitura passa a ser o instrumento de ação para decifrar códigos escritos que a história dá um de seus saltos evolutivos, o registro da informação em suportes como algo a ser legado à posteridade.

Foi a partir da linguagem e da necessidade de registro de atividades diversas, como atividade de troca de produtos, que o ser humano percebeu que seria possível o registro de sua comunicação em suporte físico. Surgem então as primeiras formas de escrita no período compreendido entre 6000 e 4000 a.C.

Uma das escritas mais significativas de que se tem notícia é a cuneiforme, por se tratar de um dos primeiros registros que traziam em si uma carga semântica em seus códigos 
(DIRINGER, 1982). Ela surge na Mesopotâmia em 3000 a.C. e possui esse nome devido à forma como era feita: a partir de cunhas. Além de sua importância semântica, essa escrita tem um espaço especial na história da humanidade, ao lado também dos hieróglifos egípcios, pois foram as primeiras a serem descobertas em suportes físicos que duraram até a modernidade.

O principal suporte da escrita cuneiforme era a argila. Os sumérios perceberam que era possível guardar seus registros das intempéries naturais e da ação do tempo por meio de blocos de argila cozidos em forno. Logo, formaram seus acervos à época no formato desses blocos, que, de tão exitosos, alguns permaneceram intactos até os dias de hoje. Tal método também permitiu uma organização da informação, próxima de uma maneira que se conhece hoje, por meio de marcações numéricas de ordem e formato contínuo (DIRINGER, 1982).

Outras formas de suporte foram encontradas para suprir a necessidade do registro da escrita. Os chineses utilizavam bambu e tecido por volta de 2000 a.C. (LABARRE, 1981). Esses suportes se configuravam como uma técnica de adaptação aos seus costumes de escrita, que é como a conhecemos até hoje, em formato de logogramas no sentido vertical. Os tecidos e bambus, por permitirem uma forma vertical de suporte, supriram as necessidades dessa escrita. É possível observar, também, que a oferta de matéria-prima faz com que ela seja utilizada diante das necessidades. Foi na China que se desenvolveu um dos tecidos mais finos do mundo, a seda, em meados de 2700 a.C., e onde se tinha uma das maiores ocorrências de bambus na natureza.

A partir desses formatos mais remotos e duradouros - pois que não se pode deixar de citar os formatos que não resistiram à história por serem biodegradáveis, como a madeira, folhagens e peles não tratadas -, novas necessidades e novos materiais foram descobertos e utilizados, como fibras vegetais, peles de animais tratadas, papel, eletrônico e os diversos outros suportes de que se tem notícia e de que se faz uso atualmente. Segundo Labarre (1981), pode-se concluir, portanto, que a história da escrita está intimamente ligada à história de seu principal e mais representativo objeto: o livro.

\subsection{Livro: uma breve história de um objeto cultural}

Ao dissertar sobre o livro se faz necessário compreender a importância que a história das tecnologias intelectuais possui na formação humana, ou seja, na formação cultural do mundo.

Segundo Lévy (1993), o pensamento humano pode ser percebido e condicionado à história das tecnologias intelectuais. Todo o arcabouço evolutivo das tecnologias que 
permitiram a percepção do mundo e a aprendizagem humana é a chave para compreender como se fez o conhecimento até hoje.

Todos os dispositivos materiais, sejam eles as placas de argila, os pergaminhos, os sinais sonoros ou os livros, são formas de memória (LÉVY, 1993). É por meio deles que é possível entender o passado, o presente e tentar descobrir o futuro. Logo, um dos principais objetos de aprendizagem, registro informacional e de guarda da memória humana, o livro, possui uma carga riquíssima de significados para a compreensão do mundo, além de ser ele mesmo, o objeto, uma fonte inesgotável de informações. Daí a importância do estudo de sua história para tentar compreender o seu futuro e o futuro da humanidade.

Para entender o livro hoje, e as novas tecnologias ligadas a ele, é necessário compreender o seu passado. Segundo Paiva, "Nem todo texto reunido é livro. Livro é o registro, o que instrui porque significa. Aquilo que tem valor, sentido, expressão. Despertando, revelando, traduzindo, relacionando" (PAIVA, 2010, p. 15).

O livro possui seu valor desde a sua gênese; sua história pode ser pensada de forma a revisitar toda evolução de seu suporte, da sociedade que o rodeou e de seus leitores.

O surgimento do livro está ligado às diversas formas de suportes físicos que o humano elaborou para registrar seus desenhos, figuras e escrita. Os primeiros meios físicos de que se tem notícia para o registro de informação são as paredes das cavernas com suas pinturas rupestres.

Entretanto, é com a tábuas de argila, feitas na Mesopotâmica por meio da escrita cuneiforme, que se começa a ter uma ideia de livro. Algumas dessas placas eram numeradas e seguiam uma lógica semântica. Outro exemplo são os pugilares, tabuletas de madeira forradas com cera - que permitiam que se "apagasse" (raspando) o texto escrito para escrever um novo, sobreposto. Eles foram utilizados no Egito, China, Grécia e Roma, por volta de 3000 a.C.

Mas foi o papiro o primeiro suporte mais eficaz para o livro. Essa tecnologia foi desenvolvida pelos egípcios por volta de 2500 a.C. A necessidade de um suporte para a escrita e a abundância da planta Cyperus papyrus às margens do Rio Nilo foram suficientes para que o Egito se tornasse um grande produtor. Feito das fibras do caule da planta, o papiro mostrou-se como o primeiro exemplar do que se conhece hoje como papel. Logo o mundo antigo conheceu essa nova técnica e o Egito se tornou o grande e único exportador de papiro para o oriente e para o ocidente - já que guardou segredo da técnica para si.

O papiro deu origem ao primeiro formato definido do livro, o rolo ou volumen, em latim. Em forma de rolo, folhas de papiro eram coladas umas às outras até formarem uma 
grande fita de papiros. Essa fita era enrolada em um bastão e armazenada no sentido horizontal. Importa observar que esse formato exigia de seu leitor o uso de ambas as mãos, uma para cada ponta do rolo. A biblioteca mais famosa da antiguidade de que se tem notícia, a Biblioteca de Alexandria, chegou a ter em seu acervo mais de quatrocentos mil rolos, podendo ter chegado a um milhão deles, segundo Paiva (2010), exemplo do tamanho sucesso que essa tecnologia egípcia obteve na ocasião.

Quase concomitante ao aparecimento do papiro, surge, na Turquia, no século II a.C., o segundo suporte mais importante para a história do livro: o pergaminho. Sua descoberta é atribuída a Eumenes II, rei de Pérgamo, que tentava com essa nova invenção fugir do monopólio egípcio do papiro (LABARRE, 1981). O pergaminho consistia em pedaços de peles de animais trabalhadas de forma a se tornarem próprias para receber textos ou figuras.

Esse novo suporte trouxe algumas novidades para o mundo da escrita e da disseminação da informação. A primeira foi sua resistência. De característica mais durável que o papiro, o pergaminho podia, a partir de então, viajar longas distâncias sem rasgar ou se desmaterializar, além de conseguir suportar as baixas temperaturas da Europa. Apesar de ser mais caro, esse suporte só começa a competir com o papiro por volta do século I d.C. O Egito deixa então de ter o monopólio do "papel" do mundo antigo.

Dos livros antigos de que se tem notícia, a grande maioria é de pergaminho, com destaque para as obras ainda hoje consideradas as mais bem produzidas na história do livro por muitos de seus colecionadores e admiradores. São alguns exemplos a Bíblia de Winchester, feita com 250 peles de vitelo; os famosos e iluminados Livros das Horas; além do Livro de Kells, uma das obras medievais religiosas mais aclamadas e famosas do mundo.

Figura 01: Bíblia de Winchester ${ }^{3}$
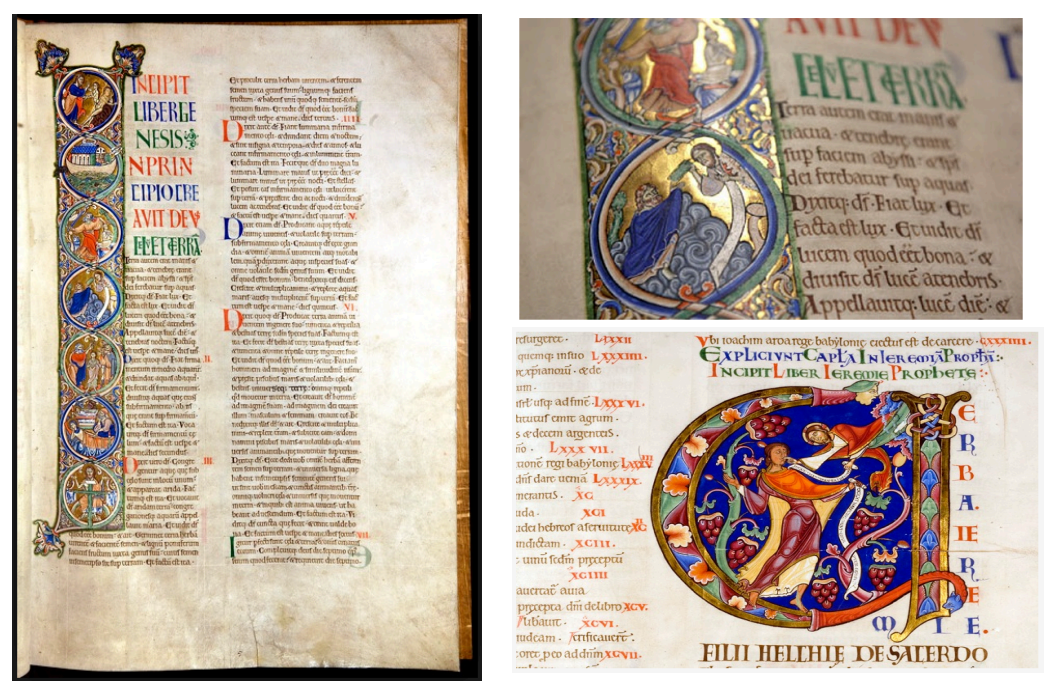

\footnotetext{
${ }^{3}$ Imagens retiras do site http://www.winchester-cathedral.org.uk/, fotos de John Crook. Acesso em: 02 mar. 2016.
} 
Figura 02: Livro de Kells ${ }^{4}$

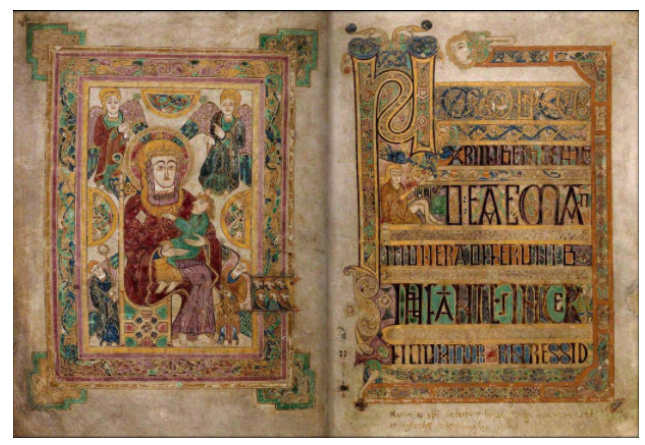

As vantagens trazidas pelo pergaminho foram substanciais, dentre elas:

1) Transporte, manuseio, fixação de pigmentação e uma opção alternativa ao papiro, o pergaminho trouxe ao mundo do livro duas grandes novidades. A possibilidade de reescritas diversas em uma mesma folha - o que era inviável com o papiro e oneroso com os pugilares foi possível com esse novo suporte, com os palimpsestos. Pergaminhos permitiam a possibilidade de "apagar" a escrita neles contida e escrever outra, novamente. Esse tipo de tecnologia possibilitou a descoberta moderna de muita história "apagada" na Idade Média, escrita por trás de textos em palimpsestos, o que, provavelmente, era feito com a finalidade de economia;

2) Outra grande novidade foi a possibilidade de juntar várias folhas de pergaminho, fixando-as por uma de suas extremidades e formando blocos, o que, por volta do século II d.C., tornou-se a primeira forma de livro de que até hoje temos notícia e conhecimento no mundo contemporâneo: o códex ou códice.

O pergaminho suplantou o papiro apenas no século IV d.C., e foi o principal suporte de livros, cartas e diversos escritos no mundo até o século XIV, quando o papel ganha popularidade na Europa e se mostra um suporte ideal para o fabrico de livros.

Chega-se então ao suporte mais famoso do livro e dos escritos: o papel. Os chineses inventam-no no ano 105 d.C., mas é somente no século VIII que chega à Europa, trazido pelos mouros à Espanha. De início, o papel não consegue competir com o pergaminho, por ser um objeto mais caro e por não ter o requinte que seu antecessor possuía. Sua massiva utilização no mundo ocidental começa no século XIV, momento em que o pergaminho começa a ficar escasso no mercado (PAIVA, 2010).

Na Figura 3 se encontra uma cronologia dos suportes do livro no decorrer da história até chegar ao papel como o conhecemos hoje.

\footnotetext{
${ }^{4}$ Imagem retirada do site https://lucian.uchicago.edu. Acesso em: 02 mar. 2016.
} 
Figura 03: Cronologia dos suportes em papel

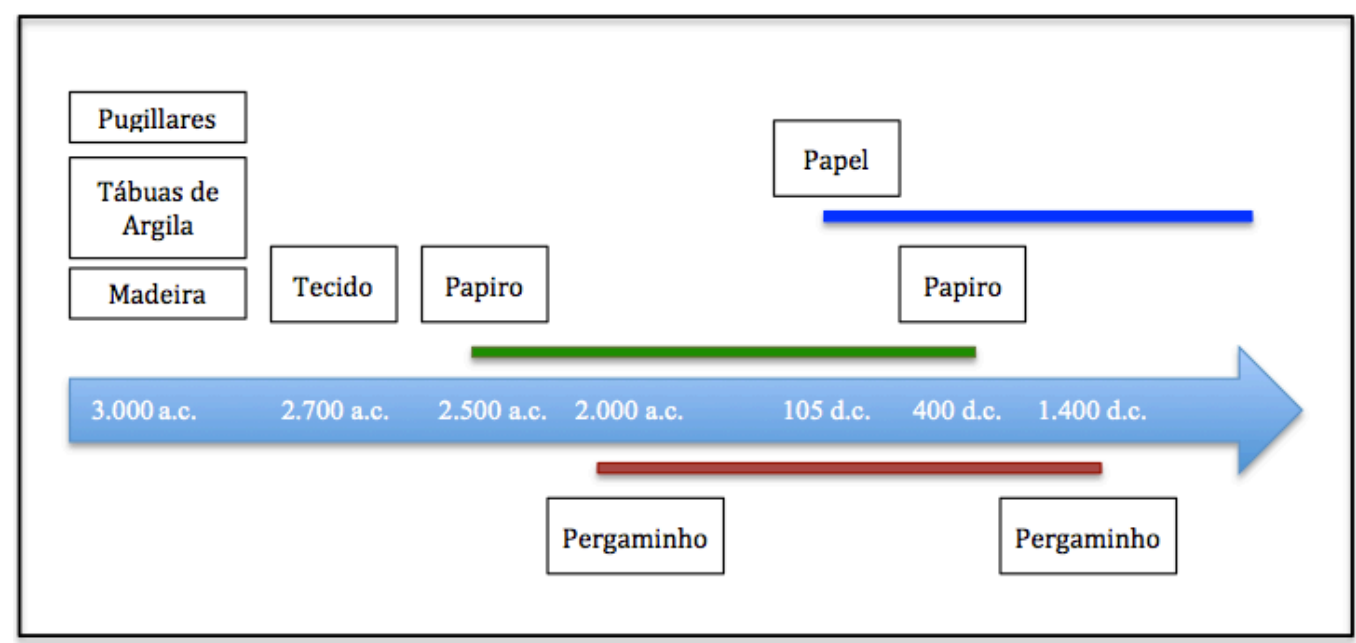

Fonte: Elaboração própria

É possível perceber com a Figura 3 que a história do livro se confunde com a história de seu suporte. Um livro feito de madeira é bem diferente do livro feito de papiro ou pergaminho. Entretanto, suas semelhanças e funções os fazem estar numa mesma linha de evolução de um mesmo objeto. O conceito de livro foi se criando a partir de suas características morfológicas e intelectuais - aqui onde a escrita e a leitura tiveram fundamental papel.

Contudo, pode-se afirmar que a maior influência na história do livro foi o ser humano. No decorrer das fases histórias - pré-história, idades antiga, média, moderna e contemporânea -, a sociedade foi impondo a esse instrumento intelectual mudanças de acordo com cenários políticos, geográficos, econômicos e tecnológicos. Portanto, é possível também analisar a história do livro por meio de suas revoluções na história humana.

Segundo Lyons (2011, p. 7), o livro é a "tecnologia mais útil, versátil e duradoura da história. Motivo de censura, perseguição e revoluções". O autor defende que o livro foi o motor de grandes rupturas na história da humanidade. Seu aparecimento no mundo e sua popularização tiveram mais força que muitos projetos monárquicos ou governamentais. Não somente o livro realizou influência sobre a história, mas ele também é a história em si, carregando em seus formatos e conteúdo uma das únicas maneiras de saber o que aconteceu no passado. Portanto, é possível identificar por meio da evolução do livro os fenômenos culturais e políticos que ele influenciou como também identificar aqueles que o influenciaram. A história desse objeto não é unilateral, tamanha sua natureza revolucionária.

Desta forma, a partir do ponto de vista de autores como Lyons (2011) e Labarre (1981), é possível, didaticamente, analisar a história do livro em cinco revoluções, quais 
sejam: a invenção do códice; a transição da leitura oral para a silenciosa; a invenção da prensa de Gutenberg; industrialização da produção de livros; e a revolução digital.

A invenção do códice está intimamente relacionada ao suporte, à tecnologia de formação do livro. Com as tabuletas de argila, com os tecidos, com as folhas de bananeira ou com o papiro, o formato do códice não seria o mais adequado. A palavra códice vem do latim códex que significava livro ou bloco de madeira; foi justamente com a madeira que os primeiros códices surgiram. Eram tábuas de madeira presas por argolas em uma de suas extremidades que formavam um grande bloco de "folhas". Entretanto, é com o pergaminho, nos séculos II e III d.C., que esse formato ganha sua melhor adaptação. Segundo Cunha e Cavalcanti (2008, p. 88), códice é um "livro antigo, manuscrito, anterior à invenção da imprensa (circa 1450), formado com folhas de pergaminho ou papiro e de valor histórico ou literário". Tal definição corrobora a revolução que essa nova forma de materialização de um suporte trouxe à história do livro.

O códice traz ao seu escritor e leitor uma nova significação de suas atividades. Ao substituir o rolo ou volumen, o códice permitiu uma revolução no conteúdo do livro e no seu manuseio. Com os rolos era muito complicada a divisão intelectual e estrutural de um texto. Não era possível, por exemplo, paginar os rolos ou dividi-los em capítulos de forma eficaz. O formato em códice permitiu um certo avanço no pensamento científico, religioso e político da época. A partir de então, um livro poderia citar outro, referenciando-o exatamente em qual página do códice era possível localizar tal citação. O papel, ou melhor, o pergaminho passou a ser melhor aproveitado, já que se poderia utilizar a frente e o verso das folhas, o que, com os rolos, não era uma atividade muito recomendada, já que a escrita por fora do rolo poderia se perder.

Outra grande vantagem do códice sobre os rolos de papiro foi a autonomia e ressignificação da função do leitor. Com os rolos o leitor tinha uma limitação física: era necessário utilizar as duas mãos para realizar a leitura. Parece pequena a mudança, mas a partir do momento em que o leitor pôde, com o códice, liberar suas mãos de tal atividade, ele passou de um leitor passivo para um leitor ativo (CHARTIER, 1999). Foi possível, a partir de então, que as pessoas fizessem suas anotações e pudessem não apenas ler, mas também produzir pensamento e conteúdos. Em termos de avanço intelectual, essa foi uma importante revolução para a humanidade. Darnton acrescenta que o códice

[...] transformou a experiência de leitura: a página surgiu como unidade de percepção e os leitores se tornaram capazes de folhear um texto claramente articulado, que logo passou a incluir palavras diferenciadas (isto é, palavras 
separadas por espaço), parágrafos e capítulos, além de sumários, índices e outros auxílios à leitura. (DARNTON, 2010, p. 40).

De acordo com Eisenstein (1998, p. 80), mudanças básicas no formato de um livro e, consequentemente, na estrutura intelectual pela qual apresenta seu conteúdo, "bem poderiam conduzir a mudanças nos padrões do pensamento"; ou seja, a mudança conduzida pelo códex nos livros pode ser um marco na forma como os leitores começaram a apreender o conhecimento ali exposto.

Pode-se perceber, portanto, que essa primeira revolução levou estreitamente à seguinte: a transição da leitura oral para a silenciosa.

Como afirma Darnton (2010) no extrato acima, não existia, antes nos rolos de papiro ou nas folhas de pergaminho, separação entre palavras, tampouco parágrafos, letras maiúsculas ou pontuação. Essa estrutura não era necessária para o costume de ler falado, ou seja, ler em voz alta era o usual desde a invenção da escrita.

Eisenstein (1998, p. 21) afirma que algumas das cópias executadas pelos monges copistas eram realizadas por meio de ditado, e que "as composições literárias eram tidas como 'publicadas' mediante sua leitura em voz alta". Isso quer dizer que o aprendizado por meio do livro poderia depender da confiança inserida na palavra falada. Pode-se afirmar, então, de haver à época uma "cultura híbrida semi-oral, semiletrada, sem qualquer equivalente preciso nos dias de hoje".

A leitura silenciosa tornou-se usual no Ocidente apenas no século X (MANGUEL, 1997). Essa prática começa nos scriptoria ${ }^{5}$ medievais, dentro das grandes abadias. Os monges copistas precisavam de muita atenção nas suas atividades de escrita e decoração artística dos manuscritos. Logo, a leitura silenciosa tornou-se regra nesses ambientes. Segundo Manguel (1997),

[...] com a leitura silenciosa, o leitor podia ao menos estabelecer uma relação sem restrições com o livro e as palavras. As palavras não precisavam mais ocupar o tempo exigido para pronunciá-las. Podiam existir em um espaço interior, passando rapidamente ou apenas se insinuando plenamente decifradas ou ditas pela metade, enquanto os pensamentos do leitor as inspecionavam à vontade, retirando novas noções delas, permitindo comparações de memória com outros livros deixados abertos para consulta simultânea. (MANGUEL, 1997, p. 67-68).

\footnotetext{
${ }^{5}$ Scriptoria eram locais nas abadias medievais reservados ao trabalho dos monges copistas, que trabalhavam na cópia manuscrita de livros antigos, tanto para Igreja quanto para eventuais trocas comerciais. Eram espécies de anexos das bibliotecas das abadias.
} 
Pode-se perceber, portanto, que o hábito da leitura silenciosa colaborou bastante para um novo paradigma da construção do pensamento humano. A produção intelectual recebe ganhos na sua forma e agilidade.

A leitura silenciosa de textos na Idade Média permitiu uma proliferação de leitores nessa época. Já que o costume agora era também o da leitura individual, as pessoas começaram a buscar a alfabetização como caminho para a informação e a produção, pois ouvir leituras de livro não encerrava mais a possibilidade de adquirir conhecimento. A partir dessa demanda - aliada ao surgimento do códice como uma forma mais duradoura, ágil e portátil de adquirir informação - acontece na Europa medieval um aumento nas vendas e na procura de livros, não muito significativo, mas suficiente para que mecenas e empresários começassem a financiar novas formas e ferramentas capazes de aperfeiçoar ainda mais a fabricação dos livros (LABARRE, 1981).

O alemão Johannes Gutenberg talvez seja o nome atrelado à história do livro mais citado e falado em todo o mundo. Tal fama se deve ao fato dele ter sido o primeiro a fabricar uma máquina de prensa de tipos móveis que teve certo sucesso e alcance dentro da Europa, por volta de 1439. Após várias tentativas de construção e de apoio financeiro de empresários interessados na elaboração da máquina, Gutenberg apresenta ao mundo europeu uma prensa capaz de imprimir em folhas de pergaminho textos diversos, sem necessidade de os ter decalcados de forma fixa em uma mesma fôrma. Ele cria a prensa de tipos móveis, a terceira grande revolução na história do livro.

Na China, 600 anos antes de Gutenberg e de sua criação revolucionária, foi feito o primeiro livro impresso de que se tem notícia na história da humanidade: $O$ sutra do diamante. Esse livro foi impresso em 868 d.C. com a tecnologia da xilogravura, ou seja, eram fôrmas fixas, sendo que para cada página ou parte do livro uma dessas fôrmas tinha que ser feita. Mais tarde, em 1.100 d.C., também na China, é criada a primeira prensa de tipo móvel. Entretanto, tal invenção não surtiu o mesmo efeito que a de Gutenberg, haja vista que a cultura chinesa possuía uma relação com a escrita muito mais filosófica e artística que os ocidentais. Logo, uma prensa que substituísse a arte da escrita chinesa não foi vista como algo revolucionário à época. É apenas por volta de 1580 que os missionários portugueses, de forma geral os jesuítas, levam a alguns países do extremo oriente as últimas novidades da imprensa ocidental (FEBVRE; MARTIN, 1992). 
Figura 04: O sutra de diamante ${ }^{6}$

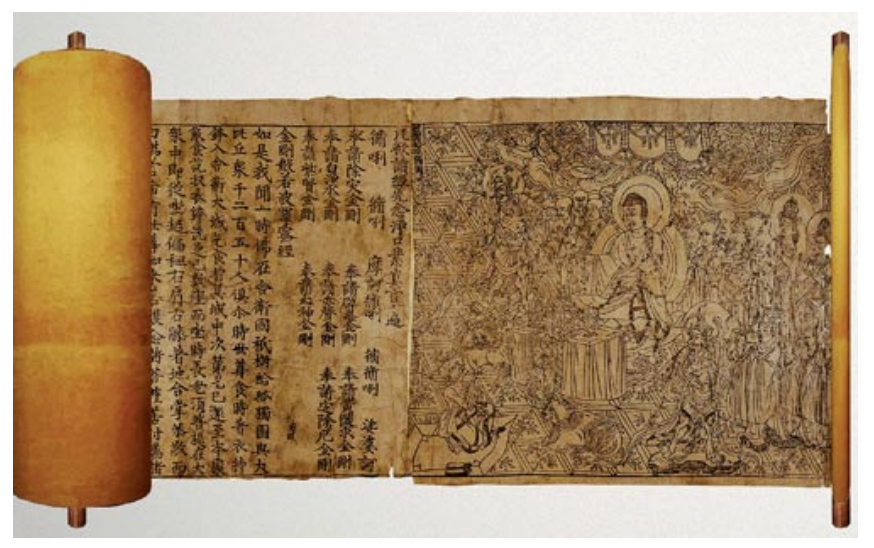

Labarre (1981) afirma que Gutenberg não tinha conhecimento da prensa de tipos móveis criada na China cerca de 300 anos de sua própria invenção. Contudo, é notório observar como se fazia necessário em todo o mundo uma invenção como essa. Dentro de 50 anos, 236 cidades da Europa já tinham réplicas da prensa de Gutenberg, tamanha a utilidade que esse equipamento proporcionou àquela sociedade, que estava aos poucos descobrindo a alfabetização e novas formas do saber religioso e científico que o Renascimento começara a proporcionar.

Os avanços da prensa de Gutenberg foram além da facilidade e rapidez na produção de livros. Foi por meio dessa invenção que a comunicação científica ganhou espaço para propagar seus conteúdos. Com a prensa era possível, então, imprimir mapas e diagramas que ajudaram, principalmente, na disseminação de conhecimento astrológico e matemático. Segundo Eisenstein (1998, p. 292), esse novo ganho perante a ciência e o conhecimento humano foi algo sem precedentes:

Antes do advento da imprensa, publicar significou muitas vezes um ditar ou ler em
voz alta. Ao contrário da cultura dos escribas, que dera espaço para "ouvir as regras
de uma determinada ciência", a cultura impressa tornou possível a distribuição
simultânea de "figuras e mapas bem feitos". Desse modo, ela não só transformou as
comunicações no seio da Comunidade do Saber, como também estabeleceu as bases
para que se pudesse confiar, de maneira nova, na capacidade humana de chegar a um
certo conhecimento das "Leis da Natureza e do Deus da Natureza" (EISENSTEIN,
1998, p. 292).

Assim como toda nova invenção revolucionária, a de Gutenberg não pôde ser utilizada logo de início em toda sua amplitude. Por razões culturais e mercadológicas, os primeiros livros impressos nas prensas de tipos móveis, os também chamados incunábulos, foram produzidos com tipos que imitavam a escrita da época, ou seja, a novidade da nova invenção

\footnotetext{
${ }^{6}$ Imagem retirada do site http://ancientprinting.weebly.com. Acesso em: 02 mar. 2016.
} 
se restringiu, em um primeiro momento, apenas à forma de produção, excetuando-se as produções científicas com diagramas e mapas; os livros continuaram basicamente no mesmo formato tipográfico que tinham antes da prensa (EISENSTEIN, 1998).

Um bom exemplo disso foram os 180 primeiros livros produzidos na prensa de Gutenberg, por ele mesmo. Foram as famosas bíblias de Gutenberg, impressas em Mogúncia, Alemanha. Tais bíblias foram impressas num período de 2 anos, e só em 1450 foram distribuídas no mercado. Uma de suas características foi a decisão de Gutenberg em imprimir 42 linhas por página e utilizar o mesmo formato de escrita que os copistas usavam antes da prensa (LYONS, 2011).

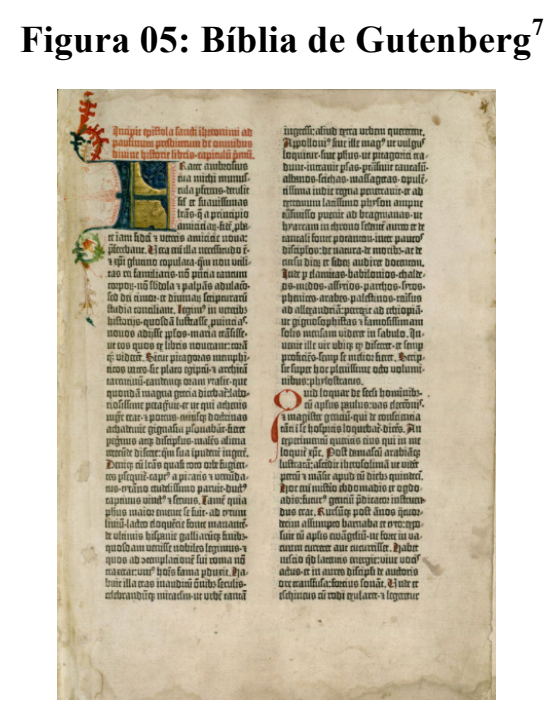

A invenção desse novo mecanismo de impressão de livros impulsionou o mercado editorial e comercial desse objeto na Europa. Esse avanço foi proporcional à criação de conhecimento e à propagação rápida de novas ideias. Segundo Febvre e Martin (1992), tal cenário foi tão importante e modificador da realidade da época, que, a partir de meados do século XVI, as congregações eclesiásticas, seus braços seculares e os príncipes e governos da época formam várias compilações de livros proibidos em diversos lugares da Europa. A censura passava desde o crivo de censores religiosos e governamentais a privilégios dados aos editores para publicações regradas de livros. Contudo, mesmo diante da censura, "os "maus livros' nunca cessaram de circular", e até o século XVIII é possível analisar o fracasso das políticas de censura de circulação desses livros, já que o comércio paralelo de obras nunca parou (FEBVRE; MARTIN, 1992, p. 352).

\footnotetext{
7 Imagem retirada do site https://pt.wikipedia.org/wiki/B\%C3\%ADblia_de_Gutenberg. Acesso em: 02 mar. 2016.
} 
Com a chegada do Iluminismo na França e na Europa no século XVIII, o livro ganha um novo fôlego. O conhecimento livre e universal pregado por esse movimento histórico vê no livro uma de suas principais formas de propagação. É nessa época que os contrabandos de livros são feitos, com auxílio dos próprios autores, e a censura é cada vez mais burlada. É também datado desse período o início da expansão da educação instrutiva na Europa. Lyons (2011) afirma que, com o início da ampliação das cidades atrelado ao pensamento iluminista, a alfabetização em algumas regiões da Europa chega à marca de $60 \%$ a $75 \%$, o que ajuda a vulgarização do livro como um objeto essencial, e não de colecionismo ou de luxo, para o cotidiano das pessoas.

O Iluminismo trouxe outro marco para a história do livro. Foi nesse período que a produção científica na Europa teve seu primeiro grande desenvolvimento, o que colaborou para o crescimento das bibliotecas nesse continente. Segundo Mey e Silveira (2009), um dos fatos que mais contribuíram para isso foi uma das ações da Revolução Francesa, que, por meio de seus dirigentes revolucionários, confiscou as grandes bibliotecas particulares e as transformaram em bibliotecas públicas, com acesso mais amplo à população. Dessa realidade nasceu a necessidade de desenvolver o que veio a ser conhecido como o primeiro código nacional de catalogação francês e a primeira vez na história que se utilizou um catálogo em fichas.

Essa necessidade de livros que se dá no século XVIII na Europa ganha um impulso técnico, ou melhor, industrial com o início da revolução industrial e com a descoberta da máquina a vapor. As distâncias começaram a encurtar e a fabricação de livros ganhou toda uma estrutura industrial para se apoiar. É nesse momento, no século XIX, que o papel de celulose é popularizado e as prensas começam a imprimir milhares de livros em papel, com qualidade bem inferior à do pergaminho, mas que permitia um acesso econômico facilitado à informação, corroborando o fenômeno da vulgarização do livro iniciado com o Iluminismo.

A partir da Revolução Industrial, o livro começa a ganhar várias facetas em sua fabricação e uso, o que colaborou para seu uso em outras áreas do saber e por outros grupos da sociedade. É no século XIX que os livros começam a ser impressos com capas; surgem os livros infantis; os livros de arte começam a ganhar espaço entre os artistas da época; almanaques são popularizados como principal fonte de informação genérica; livros como guia de viagem e de culinária aparecem no mercado editorial. Na virada para o século XX, o mundo se viu com a fabricação de livros a todo vapor, literalmente. Novos formatos e conteúdos são colocados à mão do consumidor e do leitor. Uma das principais preconizações do Iluminismo de 200 anos antes então toma forma: o livro finalmente se populariza na 
Europa, é vendido em bancas de jornais e em livrarias espalhadas por toda cidade e emprestados em bibliotecas, que já naquela época começaram a ter o sentido de públicas. Labarre (1981) afirma que:

\begin{abstract}
A revolução do livro - O desenvolvimento das técnicas e dos meios de comunicação audiovisuais é geralmente considerado como uma concorrência séria para o livro e talvez como fator de uma mutação eventual da sua forma. Não obstante, pode-se pensar que o códice mantém grandes chances futuras e que microfilmes e fitas magnéticas permanecerão ainda muito tempo como meios de substituição, pois sua utilização apresenta inconvenientes análogos aos do volumen; as tentativas feitas para aliar as novas formas às antigas foram pouco decisivas. Livros acompanhados de discos ou diapositivos obtiveram pouco sucesso; essas combinações recorriam a formas de leitura muito diferentes. Apesar disso, fala-se da "revolução do livro" e, se existe revolução, é preciso procurá-la em duas direções: a difusão e a fabricação. Escarpit vê um aspecto dessa revolução no alargamento considerável que os livros em formato de bolso trouxeram à difusão do livro. (LABARRE, 1981, p. 102).
\end{abstract}

Portanto, é possível afirmar que o livro chega ao século $\mathrm{XX}$ composto de várias facetas em seu formato e conteúdo. Várias técnicas são atreladas à sua fabricação e diversas outras formas de preservação e suporte informacional são aplicados a ele. Como afirma Labarre (1981), as principais características das revoluções do livro são sua difusão e fabricação. É nesses dois processos que a análise da história do livro praticamente se baseia.

Talvez última revolução do livro, a digital, comece já nas primeiras décadas do século XX. Um dos marcos dessa revolução, o qual é reivindicado por alguns autores da área ${ }^{8}$, seria a publicação do artigo de Vannevar Bush “As we may think”. Postular uma data estática para o início desse período da história do livro pode ser arriscado, mas o artigo de Bush deixa de forma expressa o início de tentativas reais físicas e intelectuais de transformar o acesso à informação e seu armazenamento como algo nunca visto antes.

Bush afirma, em seu artigo, que seu novo dispositivo, o Memex, seria uma inovação em termos de memória e armazenamento de informação. Traria ao ser humano do século XX a possibilidade de ter ao alcance das mãos - no caso, em uma pequena mesa de escritório toda a informação que pudesse e quisesse guardar em uma máquina com engenhos elétricos e mecânicos, além do uso da microfilmagem. Segundo ele, "Um MEMEX é um dispositivo que possibilitará a uma pessoa armazenar todos os seus livros, arquivos, e comunicações, e que é mecanizado de tal forma que poderá ser consultado com grande velocidade e flexibilidade. Seria um suplemento ampliado e íntimo de sua memória."9 (BUSH, 1945, p. 14, tradução nossa).

\footnotetext{
${ }^{8}$ CONNAWAY; WICHT, 2007; VELASCO, 2008; ARMSTRONG, 2008; TAMMARO; SALARELLI, 2008; BUFREM; SORRIBAS, 2009; PROCÓPIO, 2010; DARNTON, 2010; DZIEKANIAK et al., 2010; GALBRAITH, 2011; CHEEK; HARTEL, 2012; MAGALHÃES, 2013; SERRA; SILVA, 2013; SEHN, 2013.

${ }^{9} \mathrm{~A}$ Memex is a device in which an individual stores all his books, records, and communications, and which is mechanized so
} 
Como afirmado anteriormente, muitos autores, na literatura especializada da área, afirmam que esse conceito foi o primeiro que fez referência ao que hoje se conhece como livro eletrônico. É possível também estender tal definição à definição de leitor de livro eletrônico, o e-reader. Independentemente do conceito exato a que Bush pioneiramente fez referência, o importante é analisar a era em que tal dispositivo surgiu como parte da história do livro.

A revolução digital do livro não tem ligação apenas com a ideia de armazenamento e disponibilização da informação, como Bush afirma na conceituação de seu Memex. O desenvolvimento das telecomunicações no século $\mathrm{XX}$ influenciou enfaticamente $\mathrm{o}$ desenvolvimento de diversas formas de transmissão da informação. A televisão e, mais tarde, o próprio computador, ressignificaram a forma de apreensão do conhecimento pela humanidade. A velocidade e a instantaneidade da informação se concretizam com o fenômeno da comunicação de massa, o que mais tarde viria a calhar no conceito fundamental das mídias sociais e de seu imediatismo.

As novas mídias, como $C D-R O M s, D V D s$, diapositivos, $V H S$, memórias flash, dentre outras, entraram no mercado editorial livreiro no século XX. Algumas obras começaram a ser comercializadas com esses insumos acoplados ao códice nas estantes das livrarias. Entretanto, como afirma Labarre (1981), em comparação ao livro enquanto códice, essas novas tecnologias não se tornaram sucesso entre os leitores, e foram usadas apenas como acessórios do principal suporte e meio de informação, o próprio livro.

Chartier (1999) afirma que mais que pensar em uma nova revolução do livro, é importante entender como as novas formas de difusão e fabricação desse suporte informacional se deram no decorrer do século XX. Para o autor, a revolução do livro eletrônico "é uma revolução nas estruturas do suporte material do escrito assim como nas maneiras de ler" (CHARTIER, 1999, p. 12-13); ou seja, foi apenas com o livro em tela, sem o suporte de papel ou outro semelhante, envolvido em alguma tecnologia eletrônica ou digital, que houve de fato uma nova maneira de interação entre o leitor e a leitura. Contudo, não se pode afirmar que essa revolução digital traga ao leitor vantagens semelhantes àquelas que existiram na revolução do códice, como a possibilidade de o leitor passar do estado de agente passivo para ativo na leitura e produção do conhecimento.

Um dos maiores impactos do livro eletrônico está em sua forma. Não se pode afirmar que um romance de Graciliano Ramos seja o mesmo em uma manifestação em dois volumes, 
em um volume, em folhetins, em uma tela de computador ou em um e-reader. Ou seria possível? Essa é uma das discussões que esse trabalho se propõe a estabelecer. Todavia, fato é que o leitor possui percepções diferentes em relação aos vários tipos e suportes em que uma mesma obra pode se manifestar (CHARTIER, 1999).

Outro fato muito característico da revolução do livro é a retirada total do suporte papel, ou outro que o valha, da forma do livro (LYONS, 2011). Gutenberg não mudou a forma genuína do livro enquanto um objeto que possuía como suporte da escrita o papel ou pergaminho, e sim alterou seu formato e rapidez de fabrico ao dar uma nova possibilidade de fabricação do códice dentro do mercado livreiro com suas prensas. A revolução digital do livro realizou, em mais de dois séculos de história, uma significativa mudança: desvinculou o papel do livro. Essa talvez seja a maior característica dessa revolução.

Diante de todas as revoluções pelas quais o livro passou, torna-se vital entender seu conceito atual e como a dinâmica entre leitor e leitura foi se delineando. O conceito de livro pode extrapolar suas definições também na área técnica da Biblioteconomia. Quando se fala em livro para a atividade de catalogação, as acepções podem ser várias de acordo com a abordagem tradicional dos códigos de catalogação como o AACR2 ${ }^{10}$. Segundo Mey e Silveira (2009), os Requisitos Funcionais para Registros Bibliográficos, os FRBR, são uma alternativa para essa possível confusão. De acordo com as categorias obra, expressão, manifestação e item, pode-se pensar em diversas formas conceituais diferentes de livro. Segundo as autoras, pode-se, portanto, pensar na entidade livro como: objeto físico (item); por meio de uma especificidade como a editora do livro ou seu número de ISBN (manifestação); no contexto de quem o traduziu (expressão); de quem o escreveu e seu conteúdo temático (obra), por exemplo. O modelo conceitual FRBR permite, com essa categorização de relacionamentoentidade, contemplar as diversas conceituações que a palavra livro pode ter dentro do contexto biblioteconômico. Essa seria apenas uma forma de lidar com o processo de definição do conceito de livro dentro da Ciência da Informação, uma forma mais técnica, mas não menos legítima.

\subsection{Livro eletrônico: uma nova forma de leitura}

Vennevar Bush, como já apontado, em 1945 descreveu o futuro. Formulou a ideia de uma máquina capaz de armazenar todas as suas anotações, livros e demais comunicações, que

\footnotetext{
${ }^{10}$ AACR2: Código de catalogação anglo-americano, em sua segunda edição. É um conjunto de regras para a criação e descrição bibliográficas, pontos de acesso, entidades, localizações geográficas, títulos uniformes e outras representações de itens bibliográficos. Usada, especialmente, em bibliotecas.
} 
traria à vista de uma tela todo esse acervo pessoal, às custas de um pequeno maquinário, do tamanho de uma escrivaninha: o Memex. Seu grande êxito enquanto pensador e inventor da primeira protótipo de biblioteca portátil, ou até mesmo digital, foi em pensar que esse acervo seria depositado de forma ordenada e, consequentemente, recuperado de forma ordenada; ou seja, uma máquina que gerenciaria todos os itens de sua coleção, sem necessidade de etiquetas ou estantes (TAMMARO; SALARELLI, 2008). O Memex traria a ideia de liberdade para o seu usuário, que não dependeria do documento físico para obter informação e teria a interligação do documento disponível ao seu alcance, o que ficou conhecido como hipertexto.

$\mathrm{O}$ avanço das linguagens documentárias e as novas formas de representação da informação, que surgiram com maior força na segunda metade do século $\mathrm{XX}$, trouxeram inovações importantes para a vida dos usuários e leitores de um sistema de informação. Dentre elas se pode elencar os tesauros, as ontologias e os catálogos robustos, como os conhecidos OPACs (online public access catalog ou catálogos online de acesso público) de bibliotecas. Esses mecanismos, na Ciência da Informação conhecidos como SOCs - Sistemas de Organização do Conhecimento, foram e são de fundamental importância para a estruturação, guarda e recuperação da informação; entretanto, o mundo virtual, a grande e acessível web, trouxe aos leitores e usuários de informação um mundo de possibilidades e maneiras de customizar sua própria informação de interesse e necessidade.

Criar uma biblioteca pessoal virtual em seu computador de mesa foi uma realidade possível que o usuário encontrou nesse mundo digital. As bibliotecas e os sistemas de informação precisaram - e precisam - lidar com isso. Os downloads de artigos científicos de forma integral, os livros eletrônicos cada vez mais disponíveis nas livrarias online, os blogs e as redes sociais conseguiram, de alguma forma, ressignificar o acesso à informação na íntegra, no contexto do século XXI (DZIEKANIAK; PACHECO; KERN, 2011).

O livro eletrônico entra na seara dos novos meios de apreensão de informação que culminaram com a chegada das tecnologias da informação no século XX. Mesmo o Memex sendo considerado o primeiro protótipo da ideia de livro eletrônico, o termo electronic book foi cunhado pela primeira vez em 1968 pelo professor da Universidade de Brown (Estados Unidos), Andries Van Dam, enquanto trabalhava com sistemas iniciais de hipertexto (CONNAWAY; WICHT, 2007; ARMSTRONG, 2008; CHEEK; HARTEL, 2012). Concomitantemente, Alan Kay desenvolve seu Dynabook, um tipo de computador portátil com pouco consumo de energia e com fins específicos para leitura. Segundo Kay, assim como o livro foi a extensão do meio oral, o computador poderia ser a extensão do meio impresso. Ele defendia que o computador poderia ir além nas diversas funções que o livro tradicional 
oferecia (ARMSTRONG, 2008). Sua ideia foi posteriormente colocada em prática pela Xerox Corporation, não com as mesmas características que seu mentor propôs, mas de forma bem parecida. A ideia de Bush começou a se tornar realidade.

A proposta de livro eletrônico toma fôlego com o Projeto Gutenberg, criado em 1971 por Michael Hart, na Universidade de Illinois, Estados Unidos. O projeto teve como principal objetivo incentivar a criação, distribuição e uso daquele novo objeto digital, o livro eletrônico. Hart começou com a ideia de digitalizar as obras da Universidade de Illinois que já estivessem em domínio público para as tornar de acesso livre na internet ou em bancos de dados da rede da Universidade, com fins não comerciais e sim instrucionais (ARMSTRONG, 2008).

Outra importante iniciativa que ajudou a impulsionar a ideia e o uso de livros eletrônicos, principalmente no ambiente acadêmico, foi o projeto Oxford Text Archive (OTA), que surgiu em 1976, na Universidade de Oxford, na Inglaterra. Foi elaborado para ser uma base de textos digitais com temas nas áreas de Literatura e Linguística. Seu fundador, Lou Burnard, pensou em seu acervo digital como uma fonte alternativa e eficaz de disponibilização de informações pertinentes ao conhecimento científico e acadêmico (VASSILOU; ROWLEY, 2008).

Ambos os projetos, Gutenberg e OTA, foram precursores do que viria a ser na década de 1990 uma possibilidade real e eficiente de distribuição de conteúdo e de acesso à informação. É nesse período que surgem as primeiras bases de dados de informação digital em formato integral, ou o início do que viriam a ser nos anos 2000 as Bibliotecas Digitais. Segundo Procópio (2010), no Brasil, as primeiras iniciativas foram a Biblioteca Virtual do Estudante Brasileiro, da USP, em 1996, e a eBooksBrasil.org em 1999, ambas sem fins comerciais.

Fora do Brasil, empresários e livreiros começaram movimentações em prol da comercialização desse novo tipo de livro ou objeto digital. O primeiro ramo do mercado a ser focado foi o acadêmico, onde as grandes editoras enxergaram seu principal nicho de lucro e popularização desse novo produto (VASSILOU; ROWLEY, 2008). Em um primeiro momento, os livros eletrônicos eram vendidos em $C D-R O M$ ou entregues instalados em computadores particulares.

Em 1998 é lançado no mercado o primeiro e-reader, ou leitor de livro eletrônico: o chamado Rocket eBook; logo em seguida também foi lançado o SoftBook Reader. Eles foram os primeiros dispositivos digitais capazes de armazenar, em formato digital, milhares de 
páginas de livros eletrônicos, com especificações customizadas para esse tipo de leitura (PROCÓPIO, 2010).

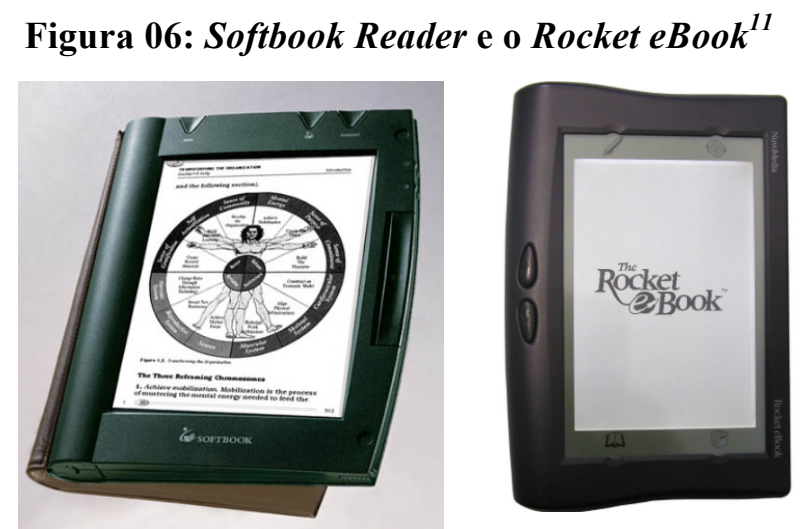

Com a chegada no mercado mundial dessa nova tecnologia era preciso entender o que seria esse insólito conceito de livro, que agora não era mais como antes. O primeiro ponto a se analisar é o batizado do objeto: livro eletrônico. Ao analisar morfologicamente a palavra livro eletrônico, aquele que se utiliza de mecanismos elétricos e mecânicos para funcionar seria mais conveniente chamar assim o aparelho eletrônico usado para a leitura do conteúdo informacional, o e-reader ou qualquer outro equipamento eletrônico, do que o objeto livro eletrônico em si. Para fins de conceituação tecnológica, o livro eletrônico como se conhece poderia ser chamado de livro digital. Seu suporte é eletrônico, devido às características físicas do equipamento que o torna possível de ser lido; entretanto, o próprio livro em si está em formato digital, em meio digital. Toda a linguagem que faz com que o livro em meio digital seja materializado é binária, ou seja: digital. Contudo, como o termo electronic book foi cunhado na década de 1970, tendo como principais tecnologias da época a elétrica, o magnetismo e a mecânica, o termo assim foi estabelecido. Logo, para fins didáticos e acadêmicos dentro da Ciência da Informação, decidiu-se nesse trabalho utilizar o termo mais conhecido e planificado na literatura da área: livro eletrônico.

A segunda questão a se analisar é a definição de livro eletrônico - de um ponto de vista mais comercial, nesse primeiro momento em meados da década de 1990. Segundo Procópio (2010), a nova tecnologia trouxe múltiplas funcionalidades que permitiram o acesso instantâneo a vários documentos digitais. Esse novo objeto digital traria dentre suas funcionalidades o controle de sua estrutura física e temática, entre elas: o ajuste de

\footnotetext{
${ }^{11}$ Imagens retiradas dos sites http://www.reviewsonline.com e http://phalese.fr. Acessos em: 03 mar. 2016.
} 
luminosidade da leitura; marcadores de página digitais; dicionário acoplado ao leitor, em várias línguas; busca por palavras em todo o texto; aumento ou diminuição do tamanho da fonte conforme necessidade; e possibilidade de publicação de uma edição pessoal de livro eletrônico. Como se pode perceber, a revolução tecnológica que trouxe à tona esse novo tipo de livro também provocou uma quebra de paradigma: o que seria um livro eletrônico?

A definição acima dada por Procópio (2010), em muitos momentos se mistura ao próprio aparelho de leitura do livro eletrônico. Foi justamente nessa incoerência conceitual que as grandes empresas de tecnologia investiram: novos modelos de negócio surgiram atrelando o livro eletrônico ao próprio conceito do leitor de livros eletrônicos, os e-readers; ou seja, a história do livro eletrônico se confunde com as tecnologias que o tornaram possível. O que não é muito diferente com a história do livro tradicional, que se confunde com a história de seus suportes. Além dessa amarração do livro eletrônico ao seu leitor ou e-reader, os modelos de negócios para esse tipo de livro foram postulados - e ainda são - pelos próprios donos ou distribuidores desses modelos. As bibliotecas ainda não entraram totalmente no mérito de construir padrões e ditar as regras que abranjam as necessidades de seus usuários no que concerne à compra e disponibilização de livros eletrônicos. Segundo Costa e Cunha (2015, p. 18), a "aquisição de livros eletrônicos para uma biblioteca é algo confuso e com inúmeros detalhes técnicos (hardware, software, financeiros e direitos autorais, entre outros)", ou seja, ao se falar em livros eletrônicos, fala-se em um campo em constante expansão e variação de conceitos e definições. Nada está muito definido ainda.

Assim como o livro dependeu da evolução tanto da tecnologia de seu suporte como da tecnologia da escrita e das formas de registro - tintas, escrita e prensas móveis -, o livro eletrônico também se vinculou bastante a essas evoluções intrínsecas à sua produção. A primeira vez que a venda de livros eletrônicos chamou a atenção do mundo foi em 2007, com a chegada do e-reader Kindle, da empresa estadunidense Amazon, que, à época, já era uma das empresas online que mais vendia livros eletrônicos; a partir de sua experiência e atinência às necessidades de seus usuários, lançou o e-reader mais famoso do mundo. A principal novidade da Amazon foi o casamento de um aparelho de leitura a um modelo de vendas remoto instalado nesse próprio dispositivo, onde mais de 300 mil itens estavam à disposição do leitor em apenas um clique no momento de seu lançamento, em 2007 (CHEEK; HARTEL, 2012). O modelo de negócios da Amazon foi tão promissor e revolucionário, do ponto de vista comercial, que em 2011 a empresa anunciou que sua venda de livros eletrônicos havia ultrapassado a venda de livros físicos em sua loja digital. Esse sucesso não parou nas vendas 
da Amazon, pois a produção e o consumo de livros eletrônicos no mundo têm se mostrado em crescimento contínuo.

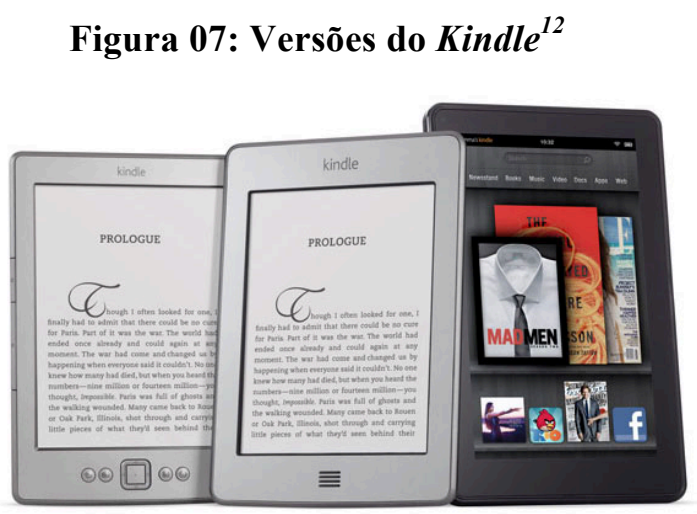

A inovação da Amazon foi aquilo que os outros e-readers não conseguiam aplicar: tornar acessível em um único dispositivo uma base de vendas online de livros eletrônicos com qualidade de acesso e apelo comercial, e não só acadêmico. Após a Amazon, outros dispositivos foram lançados no mercado, como o Sony Reader, da própria Sony; o Nook, da gigante Barnes \& Noble; e o Kobo, entre outros; todos com modelos de negócio prontos para o usuário adquirir seu livro eletrônico em segundos.

Figura 08: Kobo, Nook e Sony Reader ${ }^{13}$
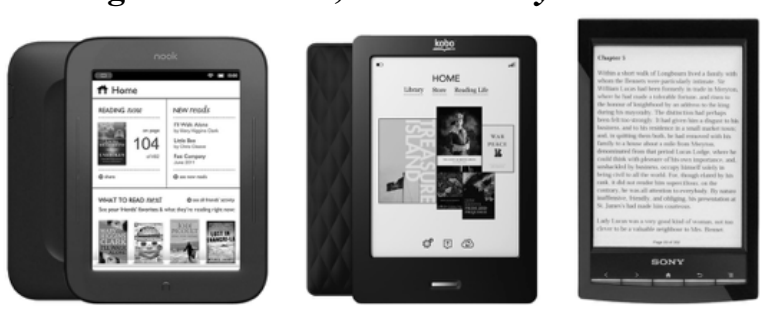

Mas não só os e-readers ajudaram na popularização do livro eletrônico nos anos 2000. Foi também nessa década que a empresa Apple lançou, em 2010, o seu primeiro tablet, o iPad. A partir de então, vários outros modelos de outras empresas surgiram no mercado. Esse é um dos dispositivos mais usados para leitura de livros eletrônicos atualmente, em conjunto com os e-readers - criados especificamente para fins de leitura -, os computadores e os smartphones com suas potentes telas.

Como é possível ler livros eletrônicos nesses gadgets ou aparelhos eletrônicos? É preciso que exista um software que permita a leitura, assim como para os livros impressos era preciso uma tinta e um suporte para que o leitor pudesse ter acesso à informação. Vários

\footnotetext{
12 Imagem retirada do site http://businesstech.co.za. Acesso em: 03 mar. 2016.

${ }^{13}$ Imagem retirada do site http://www.henriquebeier.com. Acesso em: 03 mar. 2016.
} 
softwares foram lançados no mercado para fins de leitura de livros eletrônicos, muitos na época em que a Amazon lançou no mercado seu aparelho Kindle e em conjunto seu software de leitura Kindle Reader. Hoje existem inúmeros softwares específicos para esse fim: Acrobat Reader (PDF), Adobe Acrobat eBook Reader, Mobipocket, Kobo Reader, iBooks, Google Books, entre outros.

Além de programas para possibilitar a leitura do livro eletrônico, é necessário existir softwares que sejam também compatíveis com seus diversos formatos, os quais definem sua interface e aplicabilidades. O mais famoso desses formatos é o ePub, um formato aberto, o que não significa que não possa ter proteção de direitos autorais. É muito utilizado pela Microsoft, Sony, Adobe, Kobo e Nook. Outro formato que foi fundamental na história dos ebooks é o Mobi; foi o primeiro formato utilizado pela Amazon e é proprietário. Posteriormente, a Amazon utilizou em seu Kindle o formato AZW, até 2011, muito parecido com o Mobi, mas desenvolvido pela própria empresa. A partir de 2011, a Amazon lançou no mercado seu novo formato de livros eletrônicos, o $K F 8$, o mais potente que se tem atualmente, com linguagem HTML5 e um rol de possibilidades de customização que ainda nem foi inteiramente utilizado no mercado. Entretanto, o formato talvez mais conhecido de livros eletrônicos seja o PDF, da Adobe. Ele é um formato aberto ao público desde 2008 e sua leitura pode ser feita em qualquer plataforma ou sistema operacional que suporte um leitor de PDF, o qual é distribuído online de forma gratuita. O PDF não foi amplamente popularizado dentre os e-readers, sendo um formato mais apropriado para fins de impressão, criado em sua gênese como suporte à industrialização gráfica como uma forma de garantia da permanência "de que nada seria alterado entre a arte final e a gravação na chapa de impressão" (BRANDÃO; DUQUE, 2011), ou seja, não possui as ferramentas e funcionalidades ideais que um livro eletrônico pode oferecer, apesar de ser um dos formatos mais recomendados atualmente para a preservação de documentos digitais, em seu formato PDF/A - Portable Document Format/Archiving (BODÊ, 2008).

Logo, para que toda a potencialidade do equipamento eletrônico, o e-reader, ou até mesmo outros tantos gadgets utilizados para esse fim seja alcançada, é preciso que um software esteja acoplado a ele; dependendo do formato do livro eletrônico, um software específico. Algumas distribuidoras e editoras já permitem a leitura de seus livros eletrônicos por meio de plataformas online, o que auxilia em muito a vida do leitor, que só precisaria então ter um dispositivo eletrônico com acesso à internet. Mas o que se quer analisar é a totalidade da conceituação de sua definição que o livro eletrônico trouxe ao mundo dos livros, editoras e da própria Ciência da Informação. 
Diante desse cenário, muito se fala sobre o crescimento do uso e das vendas de livros eletrônicos no mundo. Segundo a empresa de consultoria Pricewaterhouse Coopers $(P w C)$, um estudo divulgado em 2014, a venda de livros eletrônicos ultrapassará a venda de livros impressos em 2018, nos mercados da Europa e Estados Unidos (PWC, 2014). Contudo, em meados de 2015, um novo estudo da AAP (Association of American Publishers ou Associação Americana de Editores) afirmou que a venda de livros eletrônicos em 2015 diminuiu em torno de 14\% em comparação com 2014, nos Estados Unidos - maior mercado editorial do mundo (BLUESTONE, 2015), o que gerou uma série de reportagens na mídia internacional e nacional (ALTER, 2015; SÁ, 2015).

Importa ressaltar que foram as vendas de livros eletrônicos das editoras pertencentes à AAP - as quais são as cinco maiores do mercado editorial dos Estados Unidos, dentre elas as edições Penguin - que decaíram em 2015, diante das vendas de 2014. Segundo Ingram (2015) e o relatório de 2015 do Earnings Report (SEPTEMBER, 2015) - que é realizado pela Author Earnings, entidade independente dos autores dos Estados Unidos -, o que decaiu foi a venda dos livros eletrônicos das editoras participantes da AAP, e não as vendas de livros eletrônicos como um todo, que cresceu $1,4 \%$ em 2015. Nesse relatório é demonstrado que as vendas de livros eletrônicos de editoras independentes - ou as edições de autor - tiveram um aumento considerável em relação a 2014 (INGRAM, 2015). Tal efeito pode ter se dado pelo fato de, em 2015, mais bibliotecas públicas e particulares daquele país fornecerem os livros das editoras pertencentes ao AAP em seus acervos para o usuário, o que diminuiria a venda desses mesmos livros.

Portanto, pode-se afirmar que a produção, o uso e as vendas de livros eletrônicos no mundo possuem, sim, uma tendência presente e futura no seu crescimento.

O livro eletrônico não possui atualmente uma definição explícita e encerrada sobre o que ele é, tanto do ponto de vista comercial quanto acadêmico, filosófico e legal. Segundo Cheek e Hartel (2010, p. 10, tradução nossa), “O que, exatamente, constitui um livro ou um livro eletrônico? A combinação das novas funcionalidades disponíveis no livro eletrônico altera a definição de livro?"14. A questão não é simples. Desde fins da década de 1990 estudiosos da área procuram formas de responder esse questionamento.

Uma análise essencial dessa revolução de suporte, conceito e disponibilização de informação que os livros eletrônicos trouxeram ao mundo dos séculos XX e XXI é o impacto que a leitura poderá ter sofrido ou poderá sofrer com essa nova realidade. Segundo Baptista

\footnotetext{
${ }^{14}$ What, exactly, constitutes a book or what constitutes an e-book? Does the combination of new functionalities available in e-books change the definition of book?
} 
(2011), é essencial observar que as novas tecnologias dos livros eletrônicos e da internet impactaram em diferentes dinâmicas de leitura. De forma factual, todas as tecnologias que envolvem a produção da escrita e da leitura servem a um princípio: "que todo texto destina-se (sic) a ser lido, independentemente do suporte em que estiver registrado" (BAPTISTA, 2011, p. 47). Pode parecer simples, mas é a beleza da simplicidade que leva os livros eletrônicos e livros impressos ao mesmo objetivo, assim como proposto pela primeira lei da Biblioteconomia de Ranganathan: os livros - e agora os livros eletrônicos - são para serem lidos.

Outros autores defendem que o livro eletrônico não é um tipo de livro ou um sucedâneo dele. Brandão e Duque (2011) afirmam que o livro eletrônico não possui ainda um significado coerente com suas múltiplas modalidades. Segundo os autores, o livro eletrônico não seria mais que um "metalivro", algo além e diferente do livro em termos de potencialidade de informação e comunicação ${ }^{15}$. Diante do mercado editorial e de um sistema arcaico de pensamento comunicacional, o livro eletrônico tem sido vendido no Brasil e no mundo de forma equivocada e estariam representados nos "múltiplos meios eletrônicos, que estão sucedendo os livros, revistas e jornais impressos" e que "ensejam múltiplas modalidades de comunicação, quer científica, noticiosa, comercial ou de entretenimento" (BRANDÃO; DUQUE, 2011).

Antes da pesquisa que se propõe nesse estudo, não é possível tentar chegar a um consenso sobre o que viria ser o livro eletrônico para a comunidade acadêmica, o mercado editorial e para as autoridades estatais. O certo é que o mercado editorial já possui alguns conceitos definidos desse suporte, tanto é que a comercialização de livros eletrônicos já ultrapassou a de livros físicos, como já citado. Talvez o conceito nem importe tanto para esse meio, já que seus objetivos - lucro e vascularização de mercado - já estão sendo alcançados. Já a área acadêmica vem estudando mais seriamente sobre como lidar com esse tipo de objeto digital do que tentando largamente o definir. O governo, então, ainda nem possui leis claras sobre o que seria o livro eletrônico em face das legislações que definem livros e fornecem à sua produção benefícios fiscais. Logo, é possível vislumbrar um fosso intelectual no que concerne à conceituação de livro eletrônico. Seria tão importante esse conceito? É possível definir o livro eletrônico em poucas palavras? Não seria ele mesmo um "metalivro" com múltiplas funções e incapaz de ser definido dentro apenas de um campo do conhecimento?

\footnotetext{
${ }^{15}$ Metalivro aqui poderia ser entendido como a ideia do livro eletrônico não ser um livro físico em si, mas representar toda a estrutura - ou pelo quase toda ela - de um livro físico. Logo, o livro eletrônico seria a representação de um livro físico, mas com outra linguagem lógica, outro suporte, outras interações comerciais etc.
} 
Fato é que dentro da ciência é necessário saber razoavelmente qual é seu objeto de estudo, para então saber manuseá-lo, entendê-lo. Faz-se necessário delinear uma definição do livro eletrônico. Não seria essa uma poda na sua potencialidade de ser, mas uma necessidade de entendimento do que é esse devir - que um dia deverá encerrar sua evolução e se transformar em outra coisa que não um livro eletrônico.

Segundo Chartier (1999), o ato de imaginar o futuro depende daquilo que conhecemos do presente. Como será possível pensar nas múltiplas funcionalidades e potência do livro eletrônico de amanhã se não há um consenso atual do que ele é hoje? Trabalhar para o conhecimento dessa definição é trabalhar para um futuro onde o conhecimento possa continuar sendo reunido, processado e distribuído, assim como a Ciência da Informação vem fazendo nas últimas décadas.

\subsection{Biblioteca universitária: seu lugar entre os livros}

$\mathrm{Na}$ Biblioteconomia, costuma-se definir os tipos de bibliotecas existentes, quais sejam: públicas, escolares, nacionais, especializadas e universitárias (GUINCHAT; MENOU, 1994). Tal divisão se faz com base na missão e público-alvo dessas unidades informacionais. Cada um desses tipos possui um arcabouço de metodologias recomendadas a serem seguidas com base em experiências e lições aprendidas no decorrer dos anos.

A biblioteca universitária é um dos tipos mais peculiares. Segundo Borgman (2000), ela possui uma missão mais focada que as bibliotecas públicas; deve servir a uma demanda curricular e de pesquisa dos estudantes, professores e funcionários da instituição à qual pertence. Quando essas instituições possuem programas de pós-graduação, o acervo das bibliotecas universitárias se torna ainda mais especializado, sendo necessário mais conteúdo internacional e periódicos de qualidade para atender às demandas de pesquisa.

A biblioteca universitária também é um dos tipos mais antigos de biblioteca. Surge entre os séculos XII e XVI (DIÓGENES, 2012), junto com as primeiras universidades da Europa. Segundo McNeely e Wolverton (2013), as universidades representaram fenômenos urbanos europeus, que se seguiram em resposta ao longo período de ruralização e estagnação científica e intelectual da Idade Média. Aglutinações de mestres e aprendizes foram se formando nos séculos XII e XIII em pequenos locais urbanos nas recentes recriadas cidades europeias, surgindo assim as primeiras universidades. É possível compreender esse processo ao se observar o nome das primeiras universidades do mundo, dentre elas, as mais famosas Universidade de Bolonha e Universidade de Paris -, que possuem nomes dos locais onde 
surgiram. Em contrapartida, as universidades estadunidenses, em sua maioria, foram batizadas com o nome das pessoas que as fundaram (McNEELY; WOLVERTON, 2013).

As universidades vieram em resposta, ou substituição, a outra instituição do saber que era predominante na Idade Média: os mosteiros. Por muito tempo, as universidades foram os grandes centros de conhecimento científico do mundo pós Idade Média. Junto com elas surgiram seus acervos de livros e escritos, assim como era necessário nos monastérios. Entretanto, essa nova instituição do conhecimento humano possuía princípios diferentes daqueles praticados entre os religiosos em suas bibliotecas. Os novos mestres e aprendizes buscavam, sim, a disciplina e o conhecimento, mas agora com um olhar mais liberal e uma liberdade de aprendizagem só antes vista na Roma antiga.

Contudo, não é possível afirmar que as bibliotecas universitárias surgiram apenas no Renascimento com o florescimento factual das universidades. Como visto, algumas das mais antigas universidades surgiram ainda na Idade Média, na passagem de um período histórico para o outro. Segundo Diógenes (2012), as primeiras bibliotecas universitárias eram insuficientes para a formação real de seus usuários, nem sempre necessárias para que a universidade de fato funcionasse. Foi com o passar dos séculos que esse tipo de biblioteca ganhou sua real importância para o funcionamento dos cursos universitários, para a formação dos docentes e discentes das instituições.

Segundo Tarapanoff (1982), a biblioteca universitária possui como característica formadora e essencial a de ser uma organização social ou um sistema social. Por meio da geração e transmissão de conhecimento, a biblioteca universitária modifica a realidade da sociedade em que está inserida. A autora também corrobora a ideia de que esse tipo de biblioteca apenas consegue atingir seus objetivos por meio da tríade ensino, pesquisa e extensão. Também por isso, a biblioteca universitária pode ser considerada um sistema aberto (TARAPANOFF, 1982, p. 80), ou seja, "qualquer mudança que possa ocorrer no sistema, afetará as outras partes da organização universitária". Assim, a biblioteca universitária tem fundamental importância dentro da dinâmica de conhecimento de uma instituição universitária. Por esse motivo, mudanças dentro do processo dessas bibliotecas podem espelhar em mudanças na formação de todos os universitários, professores e colaboradores da instituição.

Atualmente, no Brasil, de acordo com a Lei de Diretrizes Básicas da Educação (BRASIL, 1996), o ensino superior deve estimular a criação cultural, pensamento reflexivo e o desenvolvimento do espírito científico, além de compreender as atividades de ensino, 
pesquisa e extensão. Tais objetivos devem ser alcançados sempre com o auxílio de órgãos de apoio à pesquisa, fomento ao conhecimento e suporte à busca da informação, lugar onde as bibliotecas universitárias se encaixam.

Em 2004 surge a Lei n 10.861/2004, que instituiu o Sistema Nacional de Avaliação da Educação Superior - SINAES (BRASIL, 2004). Regulamentado e aplicado pelo Ministério da Educação, o SINAES vem desde então promovendo avaliações do ensino superior com base em três premissas: avaliação das instituições, avaliação dos cursos de graduação e avaliação do desempenho dos estudantes. Dentro da avaliação dos cursos de graduação existe o indicador instalações físicas, o qual compreende os itens de avaliação das bibliografias básicas e complementares para os cursos de graduação (PASSOS; OLIVEIRA; VIEIRA, 2010). É nesse item que se destaca a importância institucional e formal da biblioteca universitária nas faculdades, centros universitários e universidades do país. Portanto, para além de sua importância conceitual e acadêmica, a biblioteca universitária é um dos itens que indicam se uma instituição de ensino superior está apta ou não a funcionar.

A partir do momento em que uma estrutura e sistema de informação como a biblioteca universitária passa a ser um fator imprescindível para a formação do ensino superior de uma nação, não só de forma ideológica, mas também de uma forma normativa - por meio de indicadores legais e regulamentados -, é possível perceber sua importância na construção do futuro acadêmico, tecnológico e de formação de um país.

O acervo é uma das peculiaridades de uma biblioteca universitária. Ele nunca será grande o bastante para atender às necessidades de seus estudantes graduandos e pósgraduandos. Várias são as possibilidades para contornar essa questão, dentre elas as comutações, repositórios institucionais, as assinaturas de periódicos via-consórcio e, no caso do Brasil, a participação nas bases de dados que o governo subsidia. A partir dessas coleções e políticas de empréstimo e acesso, a biblioteca universitária consegue acompanhar de modo satisfatório a evolução da publicação científica de diversas áreas, o que seria muito mais difícil caso fosse possível contar apenas com seu acervo de livros e periódicos físicos.

Uma das principais características das coleções de bibliotecas universitárias é a natureza híbrida de seu acervo (BORGMAN, 2000). Elas exigem uma coleção com forte tendência ao crescimento, pois atividades de pesquisa exigem uma grande gama de materiais para que o pesquisador possa ter acesso a todos os pontos de vista importantes ou necessários a seus trabalhos e formação. A forma como o desenvolvimento das coleções de acervos universitários é feita deveria refletir a necessidade de seus usuários, principalmente. Muitas 
vezes as questões de recursos financeiros e de recursos humanos também contam como pontos determinantes nesse desenvolvimento, entretanto não deveriam ser os principais. Portanto, as mesmas necessidades de informação que os usuários das bibliotecas universitárias possuem para suas publicações científicas, elaboração de trabalhos acadêmicos e realização de atividades de extensão são aquelas que a biblioteca universitária deveria fornecer por meio de seu acervo; ou seja, as pressões e exigências que o mundo acadêmico sofre são refletidas no desenvolvimento do acervo das bibliotecas e na disponibilização de seus serviços (ROSS; SENNYEY, 2008).

Segundo Cunha (2000), no ano 2000 as universidades ainda possuíam seus serviços centrados em seu corpo docente. A forma como a estrutura universitária funcionava era verticalizada, assim o conhecimento descia da experiência do professor para os então não iluminados: (a)lunos. O mesmo autor defendia que esse paradigma não se sustentaria por muito tempo, tendo em vista os avanços da tecnologia da informação e do pensamento liberal do ensino. Um dos exemplos que atualmente corrobora a previsão de Cunha é o visível avanço dos cursos de nível superior à distância e da proeminente estabilização das bibliotecas digitais na formação desse público acadêmico; ou seja, o docente não se encontra mais como ponto de partida unívoco do conhecimento acadêmico superior. A demanda de ensino agora precisa analisar o foco e a necessidade de seus estudantes, as melhores ferramentas tecnológicas para os alcançar eficazmente e que, ao mesmo tempo, facilite o ensino diante das modernidades contemporâneas.

Tal ressignificação do ensino superior atinge diretamente as bibliotecas universitárias, que vivem paralelas a ele. Desde os anos 2000, a maioria delas tornou seus catálogos - além dos processos técnicos e de referência - totalmente informatizados. Muitas bibliotecas virtuais e repositórios surgiram também nos últimos anos nessas instituições. De acordo com Cunha (2010), as bibliotecas universitárias são o "centro agregador do campus" e não ficariam aquém desse processo evolutivo. É histórico o pioneirismo dessas instituições na implementação de novas tecnologias e métodos de organização e disponibilização da informação (CUNHA; JESUS, 2012). Exemplos disso são a comutação entre bibliotecas, a implementação efetiva dos catálogos online, base de dados de artigos científicos e, mais recentemente, acervos de livros eletrônicos.

Uma pesquisa do Libray Journal em 2010 fez um levantamento do uso de livros eletrônicos em coleções de bibliotecas dos Estados Unidos (POLANKA, 2012). O resultado apontou que esse tipo de livro está presente nos acervos de $94 \%$ das bibliotecas universitárias, 
de $72 \%$ das públicas e $33 \%$ das escolares daquele país. Esse dado comprova o nível de pioneirismo desse tipo de unidade de informação. É possível transportar essa realidade para o Brasil. Segundo Serra (2014), a inclusão de livros eletrônicos no Brasil tem sido realizada prioritariamente nas bibliotecas universitárias, mesmo com os desvantajosos modelos de negócios que as distribuidoras e editoras de livros digitais proporcionam a essas instituições (COSTA; CUNHA, 2015).

Tendo em vista o cenário mundial editorial e de produção de conhecimento, o comércio de livros eletrônicos já é uma realidade em 2015. As bibliotecas universitárias entrarão nesse mercado cada dia com mais força para atender às demandas de seus usuários. Serra (2014) afirma que, assim como o que vem acontecendo nos Estados Unidos e na Europa, o Brasil seguirá a tendência de inclusão de conteúdo digital licenciado em seus acervos de bibliotecas, fenômeno esse que já se iniciou no país nas bibliotecas universitárias e que em breve será expandido para as públicas, especializadas e escolares; ou seja, é muito provável que as bibliotecas universitárias estejam já com algum tipo de experiência e lições aprendidas na condução do processo de hibridizar virtualmente sua coleção de livros.

Segundo Walters (2013), em uma pesquisa realizada em 2007 em bibliotecas universitárias dos Estados Unidos, cerca de 90\% delas já haviam adquirido ou tinham assinaturas de livros eletrônicos em suas coleções. Contudo, apesar desse número ser algo significativo, essas mesmas bibliotecas não gastavam mais de $6 \%$ de seu orçamento com esse tipo de livro. Essa constatação de uso também foi feita no Brasil por Dias, Vieira e Silva (2013) e por Santos, Sena e Oddone (2011); ou seja, o crescimento do uso de livros eletrônicos em bibliotecas universitárias é uma realidade nacional e internacional.

Contudo, mesmo as bibliotecas universitárias sendo um dos tipos de bibliotecas que mais se utilizam de livros eletrônicos em seus acervos, existem ainda muitos problemas quanto ao uso desse tipo de livro. Vários são os autores que apontam os benefícios e as grandes dificuldades acerca desse assunto. Dentre as maiores dificuldades encontradas do uso de livros eletrônicos em bibliotecas universitárias, segundo Walters (2013, p. 200-202), estão:

- Apenas metade das obras impressas adquiridas por bibliotecas universitárias estão disponíveis em livros eletrônicos;

- Limitação do acesso à informação (direitos autorais, por exemplo);

- Problemas de licenças contínuas e assinaturas (já que um livro eletrônico não modifica seu conteúdo ao longo do tempo, como no caso dos periódicos e seus novos volumes);

- Termos de licença com alto índice de variação e sem padronização; 
- Os múltiplos formatos de livros eletrônicos;

- Venda de livros eletrônicos por meio de pacotes ou coleções, e não por títulos;

- Licenças de pacotes ou coleções de livros eletrônicos que não dão ao bibliotecário controle sobre os títulos incluídos e retirados;

- Pacotes ou coleções de livros eletrônicos acadêmicos que possuem títulos não relevantes em seu conjunto;

- Preço unitário do livro eletrônico acadêmico muito alto, às vezes maior que o físico;

- Preservação dos livros eletrônicos exige mais da instituição e dos bibliotecários.

Segundo Vasileou, Rowley e Hartley (2012), as dificuldades encontradas pelas bibliotecas universitárias podem ser resumidas quanto ao preço dos livros eletrônicos; a diversidade de plataformas para cada editora ou vendedor; a falta de unanimidade entre os estudantes quanto à preferência por estudar via livros eletrônicos; DRM (digital rights management ou gestão de direitos digitais), questões de acesso e direitos autorais; os desvantajosos modelos de negócio; orçamento da biblioteca para esse tipo de livro; a demanda de mais tecnologia para manter os livros eletrônicos no acervo; e a realocação das funções dos bibliotecários.

Existe ainda outra dificuldade encontrada no uso de livros eletrônicos pelo público das bibliotecas universitárias. De acordo com Dwan (2012), é complicado fazer citações acadêmicas na utilização de livros eletrônicos. Poucos são os dispositivos que fazem a conversão das páginas do livro físico para a posição da leitura no livro eletrônico, e mesmo aqueles que o fazem - como no caso do Kindle - nem todos os livros eletrônicos vêm preparados com essa função. As citações acadêmicas são um dos pilares da construção do pensamento científico, ou seja, citar avanços e teorias passadas para construir as vindouras faz parte do método científico. Ainda segundo Dwan (2012), a própria qualidade e usabilidade das plataformas de livros eletrônicos não são da maior qualidade ainda. Problemas com ferramentas de busca, distribuição do texto e hiperlinks equivocados podem ser um entrave no processo de leitura de livros eletrônicos.

Assim, as dificuldades encontradas pelos autores acima são parecidas e seguem um padrão que diz respeito, principalmente, ao modelo de negócios fornecido pelas editoras ou distribuidores de livros eletrônicos, mas também ao preço e às formas de manuseio, que ainda não estão bastante conhecidas e difundidas pela área.

Entretanto, existem também benefícios no uso de livros eletrônicos pelas bibliotecas universitárias - não é só por modismo que os acervos desse tipo de biblioteca vêm dando 
espaço aos livros eletrônicos. Segundo Bufrem e Sorribas (2009, p. 314), os maiores benefícios do uso desse tipo de livro em bibliotecas universitárias são as novas possibilidades de estudo, o que favorece a pesquisa dentre os estudantes. De forma mais específica, outros autores (VASILEIOU; ROWLEY; HARTLEY, 2012; DWAN, 2012; CHEEK; HARTEL, 2012) listam os benefícios dos livros eletrônicos em bibliotecas universitárias como:

- Maior espaço nas bibliotecas e suas estantes;

- Possibilidade de acesso a livros para estudantes que não podem ir pessoalmente à biblioteca;

- Maior facilidade quanto à locomoção e portabilidade dos livros;

- Possibilidades de recuperação de conteúdo por meio de ferramentas de busca de texto;

- Maior acessibilidade com relação ao tamanho das letras;

- Conteúdos agregadores ao texto, como vídeos, áudio, jogos e efeitos de animação;

- Rapidez no empréstimo e devolução;

- Dificuldade de roubos e avarias.

Portanto, pode-se observar que as vantagens do uso do livro eletrônico em bibliotecas universitárias é algo real para a instituição. É preciso que os bibliotecários universitários continuem contribuindo para dinâmicas mais vantajosas nos modelos de negócio fornecidos pelo mercado, assim como na busca contínua de acesso e uso dos livros eletrônicos pelos usuários da biblioteca. Segundo Walters (2013), os livros eletrônicos terão sucesso nas bibliotecas universitárias quando três soluções forem alcançadas: editores e vendedores adotarem um modelo de negócios que mantenha seus interesses em consonância com os interesses dos bibliotecários e usuários; os livros eletrônicos se tornarem mais elegantes e tão atrativos quanto os periódicos online, sem idiossincrasias em seus formatos e padrões; e os bibliotecários tornarem o acesso e o uso dos livros eletrônicos mais fáceis aos seus usuários.

Será, então, que a biblioteca universitária terá seu conceito ressignificado em vista do que vem passando o livro físico? Talvez seja cedo para afirmar uma mudança de paradigma muito forte quanto ao conceito em si das bibliotecas universitárias. Uma instituição com mais de 600 anos de história e evolução não será modificada substancialmente por uma mudança de suporte físico e sua consequente modificação do uso da informação. A biblioteca universitária já passou por uma das maiores revoluções do livro, a prensa de Gutenberg, e se saiu bastante bem, utilizando essa inovação para auxiliar em seus objetivos. Caso a biblioteca universitária continue com seu papel de pioneira na aplicação do conhecimento biblioteconômico e tecnológico da área, poderá tomar as rédeas de sua nova definição, e 
aproveitar o advento do livro eletrônico em sua nova realidade - e talvez, um decréscimo no seu número de livros físicos - para se torna cada vez mais um lugar de colaboração, reflexão, inspiração, estudo e aprendizado, para além da guarda de acervos e coleções (DWAN, 2012).

Polanka (2012) afirma que a internet não alterou a identidade central das bibliotecas, mas o advento dos livros eletrônicos sim. Segundo a autora, os livros são um dos principais itens de identificação do conceito de biblioteca. Quando o conceito do próprio livro muda, o conceito do seu local de acolhimento também muda. Entretanto, não se sabe ainda para qual caminho andará a definição de livros eletrônicos e livros impressos para as próximas gerações, para comerciantes, usuários e bibliotecários. Essa caracterização está em processo, e a geração atual está assistindo em tempo real a segunda grande revolução do livro. A questão é saber quem continuará como espectador e quem assumirá o controle das próximas cenas tudo indica que as bibliotecas universitárias e os profissionais da informação têm tudo para conduzir bem esse espetáculo.

\subsection{Ciência da Informação e o contexto do livro impresso ao livro eletrônico}

A Ciência da Informação surge enquanto campo do saber científico formal em meados da década de 1950. Sua gênese se deu devido à necessidade que o período pós-guerra e a alta disponibilização de informação científica trouxeram à realidade das universidades, organizações e unidades de informação. Segundo Borko (1968), a Ciência da Informação é a disciplina que investiga as propriedades e comportamentos da informação, as forças que modelam o seu fluxo e os meios de processamento da informação, com fins de otimizar seu acesso e usabilidade. Aqui existe uma diferença fundamental entre a informação e a comunicação. Enquanto a primeira é um produto, uma substância ou uma matéria, a segunda é um ato ou um processo de informar. O campo da comunicação não se preocupa necessariamente com a forma como a informação da qual necessita foi coletada, analisada, processada e distribuída. O que mais importa é que a informação esteja lá para ser comunicada.

É possível então afirmar que a Ciência da Informação (CI) estuda a informação. Dessa sintética definição surgiu todo um campo do conhecimento científico, que teve o seu ponto de partida e base de conhecimento em várias disciplinas anteriores. Esses campos do saber foram, principalmente: a Bibliografia, a Documentação, a Biblioteconomia e a Museologia. A 
complexidade do campo de estudo da CI começa com a definição do que vem a ser a própria informação, o que não deixa de ser uma grande metalinguagem.

Belkin (1978), em seu artigo Information concepts for information science, elenca uma série de definições e abordagens do conceito de informação voltados para a CI. Uma definição mais clássica percorre a ideia de que tudo o que é registrado em forma de signos representativos e legíveis, criados pelo ser humano, é informação; ou seja, informação seria o conhecimento ou dados advindos do ser humano e registrados de alguma forma em um suporte físico. Essa definição corrobora com a do francês Le Coadic (2004). Belkin (1978) cita outros conceitos mais cognitivos e abstratos de informação, onde tudo que se produz de forma tácita, a partir da consciência do ser humano, também é informação para a CI.

Outros autores mais contemporâneos afirmam que a informação pode ser tanto aquela registrada em códigos alfabéticos/binários ou tudo aquilo que é produzido pelo homem, como artefatos, objetos e conceitos. É desse pressuposto que parte o teórico Buckland (1991), que defende que a representação do conhecimento é necessariamente a informação como coisa; ou seja, mesmo uma árvore na natureza - uma "coisa" não fabricada ou instrumentalizada $a$ priori pelo ser humano - pode ter seu conceito realocado dependendo da situação na qual é posta. Newton, no século XVII, provavelmente interpretou a macieira ao seu lado como uma valiosa informação para toda a teoria da gravidade, que viria a formular a partir de então. Logo, como não dizer que a árvore ou a maçã de Newton não foram objetos dotados de informação num dado momento? Buckland (1991) afirma que até gotas de sangue com curta vida de duração podem ser informação, e muito preciosa, dependendo do objetivo investigativo a que serve, por exemplo. Muitos críticos a essa definição de informação afirmam que não há como exercer sobre esse tipo de informação como coisa os processos intrínsecos de investigação, fluxo e processamento da informação aos quais Borko se referia já em 1968. Talvez aqui esteja uma das mais importantes características da Ciência da Informação: ela é uma ciência fundamentalmente interdisciplinar; ou seja, vários conceitos e visões de outras áreas podem ser incorporados ao seu corpus científico desde que traga os devidos benefícios ao objetivo final da CI.

Grande parte dessas definições e acepções encontram sua base conceitual na equação fundamental da Ciência da Informação de Brookes (1980): $\mathrm{K}(\mathrm{S})+\Delta \mathrm{I}(\rightarrow \Delta \mathrm{K})=\mathrm{K}[\mathrm{S}+\Delta \mathrm{S}]$. Tal equação reza que a estrutura inicial do conhecimento $\mathrm{K}(\mathrm{S})$, adicionada a um novo conhecimento adquirido por meio de uma informação $\Delta \mathrm{I}$, gera um novo estado de conhecimento, que seria o $\mathrm{K}[\mathrm{S}+\Delta \mathrm{S}]$; ou seja, para Brookes (1980), antes de um indivíduo ter acesso à informação ele está em um estado anormal de conhecimento, com uma deficiência 
no seu entendimento sobre algum assunto. Ao ter contato com a informação que possa dar propensão para que seu conhecimento a respeito de alguma matéria cresça ou se torne mais completo, ele passa para um novo estado do conhecimento, sem julgamento de valor se esse seria um conhecimento correto ou não, mas sim um conhecimento agregado a uma nova informação. Essa equação é uma das bases para todo o pensamento da Ciência da Informação e que engloba a maioria dos conceitos de informação trazidos por Belkin (1978) em seu artigo. Assim, a informação sendo registrada em um suporte físico em forma de signos, um objeto ou coisa, ou apenas um pensamento na cabeça de um ser humano, desde que ela cumpra os objetos da equação fundamental da informação, estará sendo objeto de análise e estudo da CI.

A partir dessas visões e conceitos sobre o objeto de estudo da Ciência da Informação, defende-se nessa pesquisa que o livro, como um dos principais objetos informacionais do mundo antigo e moderno, é talvez um dos grandes objetos de estudo desse campo do saber.

As principais disciplinas que formaram o arcabouço teórico para a formulação da CI possuem ou têm em algum momento o livro como objeto de trabalho ou pesquisa. A Museologia e a Documentação tratam tanto do livro como de outros suportes de informação; entretanto, até meados da década de quarenta do século XX o livro foi o principal instrumento de divulgação do conhecimento humano; logo, pode-se afirmar que ele estava entre os principais objetos de trabalho dessas disciplinas, principalmente a Documentação. A Bibliografia surgiu, de forma mais significativa, após a imprensa de Gutenberg, realizando a atividade fundamental de seu escopo teórico: enumerar obras/livros publicados ou escritos sobre determinado assunto, em determinado local. Já a Biblioteconomia possui em seu próprio nome a referência ao objeto e suporte a que remete imediatamente: o livro. Desde os papiros da Biblioteca de Alexandria até os atuais livros eletrônicos, a área de atuação desse campo do saber é prioritariamente sobre selecionar, organizar e disponibilizar livros - com as devidas ressalvas para os outros tipos de suporte da informação, também englobados pela biblioteca.

Pesquisa realizada em 2014 (PESQUISA..., 2014) pelo Observatório da Leitura, com mais de 500 entrevistas com bibliotecários de bibliotecas de todas as regiões do Brasil, constatou que a grande maioria dos acervos dessas bibliotecas é composto de livros de literatura em geral. Quando perguntado qual tipo de obra deveria fazer parte de um suposto acervo digital nessas bibliotecas, 88,06\% responderam que seriam livros eletrônicos de literatura, 76,3\% livros eletrônicos que apoiem os trabalhos e pesquisas escolares e 67,8\% 
revistas digitais; ou seja, o livro - físico ou digital - ainda é o principal objeto de consumo intelectual dos usuários de uma biblioteca, na visão dos profissionais da informação.

Nos primeiros anos do século XXI, o livro entrou para as novas discussões do campo da CI e da Biblioteconomia. Como lidar, de repente, com um novo suporte para um dos objetos mais antigos do conhecimento humano? O livro entra em sua revolução digital com toda a força. Gadgets, tablets, smartphones e leitores de livros eletrônicos são vendidos cada dia em maior número nas lojas e na internet, promovendo o real uso dos livros eletrônicos. A indústria editorial não acadêmica começa a delinear seus planos de negócio para a realidade de consumo desse novo suporte, ou novo livro. É preciso imediatamente aprimorar as pesquisas e os conceitos que irão girar em torno do livro. O status quo dos processos inerentes ao livro ganha um novo paradigma, ou pede por mudanças. Redes de venda de livros, como a Amazon, assumem que a venda de livros eletrônicos já ultrapassou a de livros físicos. Bibliotecas digitais começam a ter cada dia mais espaço nas instituições e universidades (CUNHA, 2010).

Outra discussão necessária que deveria estar no âmbito da CI é a definição do conceito de livro eletrônico. Muitas são as definições informais e científicas, entretanto pouco se tem em consenso sobre uma que englobe e encerre o assunto. Vassilou e Rowley (2008) realizaram, em 2008, uma pesquisa em busca da definição de livro eletrônico, em uma amostra de 37 espécies de conceituações na literatura, em língua inglesa, desse objeto digital. As autoras não localizaram uma definição final de livro eletrônico e sim um progresso dessa definição, a partir das necessidades dos usuários e do avanço tecnológico que cerca esse suporte. A pesquisa propôs que qualquer definição acerca dos livros eletrônicos deve englobar quatro itens: a natureza digital ou eletrônica do item; a real alusão ao conceito conhecido de livro; alguma indicação da natureza do conteúdo dos livros eletrônicos; e alguma referência sobre as tecnologias que englobam aquele livro eletrônico. A conclusão da pesquisa de Vassilou e Rowley (2008) permitiu que fosse proposta uma definição em aberto do livro eletrônico em duas partes:

(1) Um livro eletrônico é um objeto digital com conteúdo textual e/ou outro conteúdo, que surge como resultado da interação conhecida do conceito de livro com as características que advêm de um ambiente eletrônico.

(2) Livros eletrônicos normalmente têm características de uso, como busca e referência cruzada, links de hipertexto, marcadores, anotações, destaques, objetos multimídias e ferramentas interativas ${ }^{16}$. (VASSILOU; ROWLEY, 2008, tradução nossa).

\footnotetext{
${ }^{16}$ (1) An e-book is a digital object with textual and/or other content, which arises as a result of integrating the familiar concept of a book with features that can be provided in an electronic environment. (2) E-books, typically have in-use features such search and cross reference functions, hypertext links, bookmarks, annotations, highlights, multimedia objects and interactive tools.
} 
Assim, não há uma norma ou lei final que conclua a definição de livro eletrônico. Por meio de uma pesquisa de revisão sistematizada da literatura, as autoras puderam garimpar o que de consenso havia na área da CI sobre a definição de livros eletrônicos. Contudo, deve-se ressaltar que quase uma década se passou desde a conclusão da pesquisa; e muita tecnologia, uso e reformulação aconteceram em torno dos livros eletrônicos.

Para Armstrong (2008), os livros eletrônicos seriam denominados como livros com conteúdo disponível de forma digital ou eletrônica, já que a experiência fundamental da leitura não seria alterada - apenas a sua forma; ou seja, o autor possui um ponto de vista do livro eletrônico perante sua função e seu conteúdo. Essa talvez seja a visão mais revisitada na literatura da área. O livro eletrônico só pode ser estabelecido no mercado e intelectualmente porque existiu o livro impresso antes dele, da forma que foi possível defini-lo até agora. Weitzel (2000) contribuiu para o conceito de livro eletrônico, mesmo sem citá-lo, ao afirmar que os documentos eletrônicos foram a maior revolução - junto com a internet - depois da prensa de Gutenberg. Segundo a autora, ele não passa de mais um suporte do conhecimento registrado que possui duas características agregadoras expressivas, quais sejam: grande capacidade de armazenamento e facilidade de manipulação de dados.

Bufrem e Sorribas (2009, p. 305) afirmam que o livro eletrônico pode ser o "aparelho de leitura de textos em formato digital, que oferece funcionalidades de um livro de papel", dentre as quais, a mais importante: a portabilidade. As mesmas autoras continuam com uma definição diversa de livro eletrônico, que poderia ser entendido como um "texto em formato digital", que seria obtido via Internet ou CD-Rom. Nessa conceituação, tratam do livro eletrônico como um texto eletrônico, com todas as qualidades que esse tipo de formato pode fornecer, como: atualização e correções automáticas, disseminação e produções rápidas, interatividade, possibilidade de ausência de intermediador na produção e publicação de conteúdo e alcance ilimitado - já que a internet é a principal ponte de acesso a esses textos. Portanto, Bufrem e Sorribas (2009) também buscam definir livro eletrônico tanto pelo seu conteúdo como pelo seu aspecto tecnológico.

Seguindo essa lógica, Dias, Vieira e Silva (2013) também buscam conceituar livro eletrônico como algo indissociável entre conteúdo e suporte. Os autores afirmam que assim como o livro tradicional não pode ser dissociado do seu formato conhecido - a forma em códice e o material em papel -, o livro eletrônico não pode ser definido sem se pensar no aparato tecnológico que o faz ser, existir. A proposta de definição feita pelos autores é que o livro eletrônico 
[...] é a denominação da espécie, da classe (ou gênero) de leitores eletrônicos (ereaders), que tenham o animus de mimetizar e expandir as funcionalidades de um livro tradicional e, portanto, com pelo menos um conteúdo informacional (obra) contido em seus dispositivos de memória; dessa forma, nesta espécie de leitor eletrônico é indissociável o conteúdo informacional (corpus misticum), em formato digital, com o dispositivo tecnológico (corpus mechanicum) que processa, exibe e permite a interação com o conteúdo informacional. (DIAS; VIEIRA; SILVA, 2013, p. 11-12)

Portanto, mais uma vez se vê a definição de livro eletrônico como um conteúdo informacional que não pode ser dissociado de sua tecnologia - que podem ser várias.

Besen e Kirby (2012), em relatório feito para a ALA (American Library Association), afirmam que as diferentes dinâmicas que o livro eletrônico assume em uma biblioteca são as principais características que o distinguem de um livro impresso. Segundo os autores, o livro eletrônico não precisa ter várias cópias para que mais de um usuário possa ter acesso a ele; não podem ser perdidos ou roubados; não é necessário que o usuário vá presencialmente à biblioteca para emprestar um livro; no caso de haver uma lista de desiderata ${ }^{17}$ na biblioteca, não é necessário que o usuário espere que o livro físico seja escolhido/licitado, comprado e entregue na biblioteca até estar pronto para empréstimo; e, finalmente, não é preciso que o usuário vá pessoalmente à biblioteca devolver seu livro emprestado. Ou seja, o livro eletrônico seria um avanço a todas essas etapas no processo de empréstimo e uso de um livro ou objeto informacional de uma biblioteca. Toda essa modificação no ciclo informacional que passaria a ser remoto ou virtual - levaria o livro eletrônico a ser definido de outra forma, diversa do livro físico. Aqui o livro eletrônico busca ser definido mais por suas funções do que por seu suporte tecnológico. Entretanto, mesmo com esse intuito, os autores acabam perpassando em algum momento pelas funcionalidades tecnológicas que o suporte do livro eletrônico pode fornecer à biblioteca e aos usuários.

Em uma definição formal, Cunha e Cavalcanti (2008, p. 233) tratam do livro eletrônico mais como forma do que como conteúdo. Segundo os autores, o livro eletrônico seria "o que foi convertido ao formato digital, ou originalmente produzido nesse formato, para ser lido em computador ou dispositivo especial destinado a esse fim"; na mesma definição, os autores colocam como sinônimos de livro eletrônico os seguintes termos: e-book, electronic book, interactive book, multimídia book, livro digital, livro interativo e livro multimídia, esse último relacionado ao hiperdocumento. Portanto, aqui, fez-se a preferência pelo termo livro eletrônico e pela definição que delimita justamente o que de mais diferente há entre o livro tradicional e o livro eletrônico.

\footnotetext{
${ }^{17}$ Desiderata é uma "lista de livros ou outros documentos desejados pela biblioteca para possível aquisição" (CUNHA; CAVALCANTI, 2008, p. 120).
} 
Outra definição de dicionário aparece na página do Online dictionary for library and Information Science. No vocábulo electronic book, a definição encontrada foi que o livro eletrônico seria "uma versão digital do livro tradicional impresso concebida para ser lida em um computador pessoal ou em um leitor de livro eletrônico (e-reader)" (REITZ, 2016, tradução nossa) ${ }^{18}$. Ainda segundo o dicionário, algumas bibliotecas já disponibilizam os livros eletrônicos em seus catálogos, e para que eles sejam lidos é preciso que exista um formato universalmente aceito e um sistema simples de entrega, talvez de download. Os sinônimos apresentados pelo autor para livro eletrônico seriam: digital book, e-book, ebook e online book. Essa definição também segue a linha de conceituar o livro eletrônico mais pelo seu suporte ou formato tecnológico do que pelo seu conteúdo.

Alguns autores da área da CI têm cunhado e utilizado um termo novo para definir ou nomear esse novo objeto digital. Seria uma definição que abrange quase todas as formas de utilização das tecnologias existentes e usos para os livros eletrônicos e livros digitais. Segundo Grau, Oddone e Dourado (2013, p. 5), a denominação mais coerente seria de Livros Digitais e Eletrônicos, os LDEs. Segundo as autoras, há diferença entre livro digital e livro eletrônico, onde o primeiro seria o livro codificado "em arquivos binários legíveis por qualquer dispositivo de processamento de dados", e os livros eletrônicos os "codificados em arquivos binários acessíveis apenas através de dispositivos dedicados, como e-readers e tablets específicos". Essa nova nomenclatura fora cunhada tendo como suporte a definição de documentos digitais e eletrônicos dada pelo Conarq ${ }^{19}$ (2010 apud GRAU; ODDONE; DOURADO, 2013, p. 5), onde reza que "todo documento digital é eletrônico, mas nem todo documento eletrônico é digital".

Para exemplificar melhor, Grau e Oddone (2015, p. 5) dão alguns exemplos sobre quais tipos ou suportes envolvidos com os LDEs poderiam distingui-los entre eletrônico ou digital. Segundo as autoras, os livros digitais seriam aqueles disponíveis em versões ou formatos .html, .txt ou .pdf na internet. Para que seja possível sua leitura, seria necessário um computador conectado à Internet "e um programa de navegação, entre os quais podem ser mencionados o Internet Explorer, Mozilla Firefox, Google Chrome, Apple Safari, entre outros". Já os livros eletrônicos seriam aqueles disponibilizados nas versões .epub, .mobi, .azw e .ios, dentre outras. Segundo as autoras, para lê-los "é preciso visitar lojas especializadas, baixar arquivos com o conteúdo dos livros e fazer upload desses arquivos em aparelhos como Kobo, Kindle e iPad, entre outros, ou instalar os arquivos diretamente nos

\footnotetext{
${ }^{18}$ A digital version of a traditional print book designed to be read on a personal computer or e-book reader.

${ }^{19}$ Conselho Nacional de Arquivos - http://www.conarq.arquivonacional.gov.br.
} 
aparelhos" ou, ainda, "instalar no computador programas especiais de leitura para abrir e ler esses mesmos arquivos”. Portanto, as autoras defendem que é possível caminhar para uma abordagem mais coesa dentro do campo da CI no que tange ao conceito de livro eletrônico e livro digital. Elas ainda defendem que, caso esse campo de conceituação continue incerto e sem grandes avanços, a pesquisa sobre o tema em torno do LDE estará prejudicada (GRAU; ODDONE, 2015).

Nesta pesquisa realizada por Grau e Oddone (2015), foi feito um levantamento na literatura da área de CI nacional e internacional, por meio de base de dados disponíveis no Portal de Periódicos da CAPES, em busca de periódicos acadêmicos sobre Livros Eletrônicos e Digitais, os LDEs - como as autoras os nomeiam. O período abrangido pela coleta foi de 2011 a 2013; e os resultados encontrados deram um total de 684 referências líquidas, onde a grande maioria estava em inglês. Para que os dados pudessem ser analisados, fora realizada uma categorização dos dados, a exemplo do que Vassilou e Rowley (2008) fizeram. O resultado encontrado foi que os periódicos estudados mostram que o leque de temas relacionados aos LDEs é bem amplo, abrangendo várias abordagens. Dessa forma, Grau e Oddone concluíram que esse novo tipo de livro é encontrado no estudo de várias áreas da sociedade, ou seja, ele é um “objeto de estudo privilegiado" por permear várias áreas do saber - algo interessante de se observar, já que essa é uma das características da própria CI e de sua interdisciplinaridade. As autoras também observaram que os estudos sobre LDE cresceram significativamente nos últimos anos, o que aponta um maior interesse por parte dos profissionais da informação. Um dos resultados obtidos no levantamento foi a diversidade de definições e nomenclaturas para os livros eletrônicos e digitais, o que mostrou certa preocupação das autoras. Portanto, é possível constatar que na literatura da área ainda se busca um consenso sobre o que venha ser o livro eletrônico, ou, como as autoras defendem, os LDEs.

Portanto, diante da literatura analisada é possível afirmar que ainda não há um consenso quanto à definição de livro eletrônico no Brasil e no mundo. Contudo, a definição de um objeto de estudo contribui para que o conhecimento do mundo que nos cerca seja mais enriquecido, e possa ser cientificamente estudado. Quando se descobrem novos elementos da tabela periódica, logo os cientistas buscam nomeá-los e traçar as fórmulas químicas que os definam enquanto objeto e substância de um campo do saber e, consequentemente, do mundo. Não poderia ser diferente com esse novo tipo de objeto digital. De acordo com Dahlberg (1978, p. 106), a percepção que se tem do mundo "cresce continuamente assim como se enriquece sempre mais a intensão dos nossos conceitos relativos ao mesmo"; logo, o livro 
eletrônico, sendo uma continuação da história do livro, é uma forma de alargamento do conhecimento que se tem desse mundo do saber, ou campo da CI. Entretanto, ainda de acordo com Dahlberg, saber cada vez mais sobre as características do livro eletrônico não significa que o conceito dele seja cada vez maior ou mais complexo. Acaso não se tome como científico e técnico o estudo sobre o livro eletrônico, seus diversos conceitos expostos na literatura, mídia ou artigos acadêmicos podem apenas resultado de mais um fenômeno linguístico do alargamento de um léxico da língua.

Alvarenga (2001, p. 6) nos ensina que a dinâmica na classificação de documentos no decorrer do tempo é um sinal da evolução, ou do "sacudir", da "certeza de especificidade que pode ocorrer de objetividades inadvertidas oriunda (sic) de nossos sentidos imediatos". De acordo com a evolução da dinâmica tecnológica que cerca o mundo da CI, é possível acompanhar alguns conceitos no decorrer do tempo. A biblioteca era tida como um prédio/sala/local físico com um acervo de documentos, principalmente livros e periódicos, com alguns locais de estudo e com funcionários reais trabalhando e orientando seus usuários. De alguns anos para cá, esse conceito foi alargado, e novas definições foram tidas como realidade - vide o caso das bibliotecas digitais e dos repositórios digitais.

Ainda segundo Dahlberg (1978, p. 105), um “conceito é a soma total de suas características", assim como no caso do conceito que ainda não tenha um nome específico, seria possível construí-lo pelo conjunto de suas características descobertas. Portanto, pode-se afirmar que o livro eletrônico seria a soma de suas características definidas até então na literatura científica da área. Essa é a única afirmação que se pode fazer com certeza sobre o que tange o conceito de livro eletrônico atualmente.

Portanto, para fins didáticos, o quadro abaixo relaciona todas as definições sobre livro eletrônico analisados nessa revisão de literatura:

\section{Quadro 01: Definições de livro eletrônico}

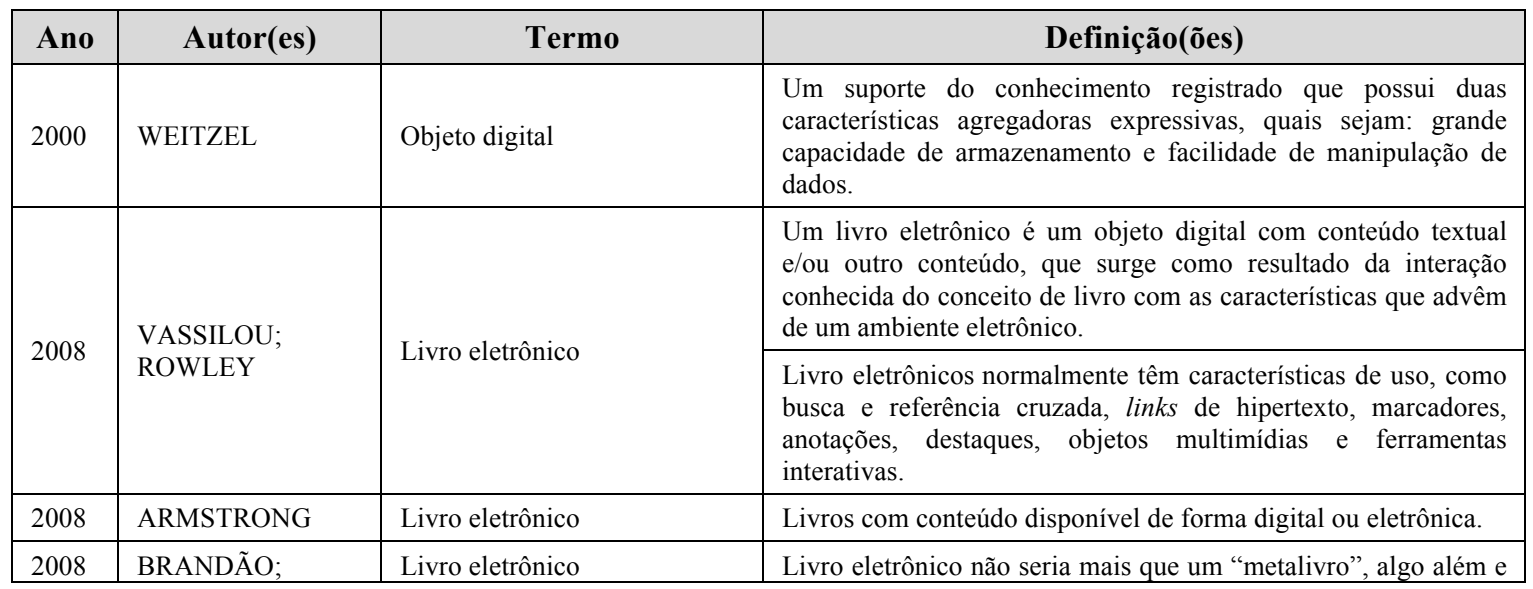


Continuação

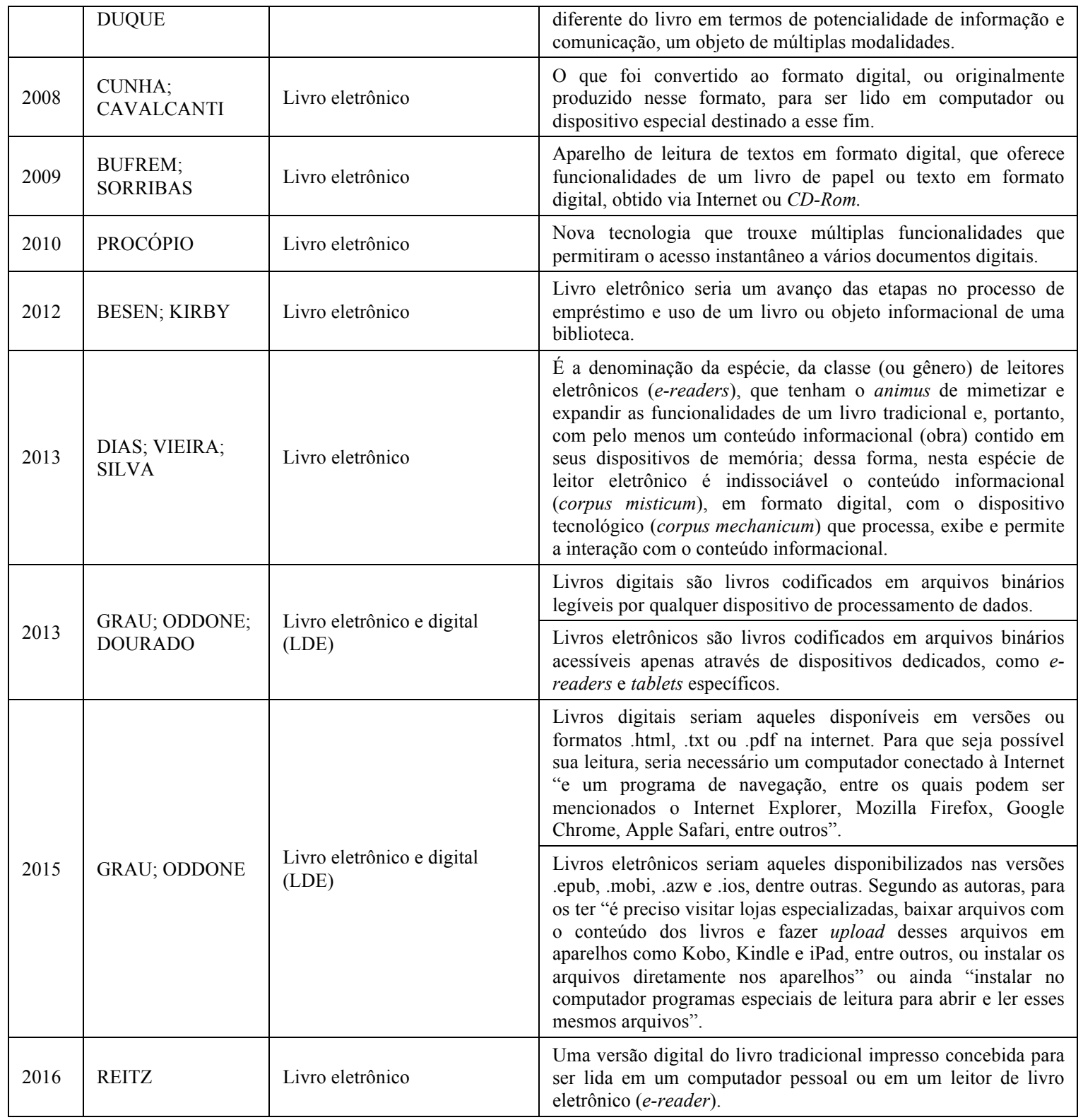

Fonte: Elaboração própria.

É possível perceber que as definições que mais se preocupam com a continuidade e estabilidade acadêmica do termo são as de Vassilou e Rowley (2008) e das brasileiras Grau, Oddone e Dourado (2013) e Grau e Oddone (2015). Os conceitos que essas autoras buscam levam em consideração tanto o conteúdo quanto as funcionalidades tecnológicas que um livro eletrônico pode ter.

Partindo para a busca de uma definição mais jurídica ou legislativa de livro eletrônico, no Brasil não existe atualmente uma definição legal ou normativa. O livro físico ou impresso possui definições oficiais consolidadas no país. A Lei $n^{0}$ 10.753/2003, que institui a Política Nacional do Livro, define o livro como: 
[...] a publicação de textos escritos em fichas ou folhas, não periódica, grampeada, colada ou costurada, em volume cartonado, encadernado ou em brochura, em capas avulsas, em qualquer formato e acabamento"

E ainda equipara ao livro os "livros em meio digital, magnético e ótico, para uso exclusivo de pessoas com deficiência visual". (BRASIL, 2003).

O livro eletrônico não fora contemplado nessa definição legal de 2003. Um dos grandes problemas que esse vácuo conceitual, tanto legal quanto acadêmico, proporciona são os entraves gerados na indústria editorial, o orçamento do governo destinado à compra de livros eletrônicos, incentivos de agências de fomento e pesquisa e o encarecimento do acesso a esse tipo de livro. Mais precisamente, no campo da CI e da Biblioteconomia, existe uma brecha não concluída sobre como processar, emprestar e disponibilizar livros eletrônicos no que concerne aos direitos autorais, formas de seleção e aquisição, armazenamento, preservação e empréstimo aos usuários.

Na Constituição Federal de 1988, em seu artigo 150, é vedada a instituição de impostos sobre livros, jornais, periódicos ou papel destinado à sua impressão; os livros físicos possuem um incentivo fiscal; entretanto, o livro eletrônico não pode se beneficiar dessa prerrogativa, o que afeta não somente a venda do livro eletrônico em si - encarecendo o produto final e diminuindo o acesso pelo leitor, usuário de biblioteca e unidades de informação - mas também atingindo diretamente o meio físico pelo qual o livro eletrônico precisa ser lido. A Constituição, ainda no artigo 150, assume que a isenção fiscal também atinge o papel no qual é impresso o livro; logo, editores e produtores brasileiros reivindicam que os tablets e leitores de livros eletrônicos também possam ter tal benefício, afinal o livro eletrônico precisa de um suporte físico para ser lido, assim como o livro impresso.

A Câmara dos Deputados discute, desde 2012, o Projeto de Lei n ${ }^{\circ}$ 4534/2012 que propõe uma atualização no conceito de livro que está contido na Lei ${ }^{\circ}$ 10.753/2003 (BRASIL, 2012). A inclusão do livro eletrônico no rol dos produtos equiparados ao livro já foi feita nesse projeto de lei, entretanto a inserção dos leitores digitais ainda é polêmica (RODRIGUES, 2014).

O Projeto de Lei 4534/2012 vem tentando, por meio de emendas e substitutivos, englobar alguns outros conceitos de livro, com especial atenção ao livro eletrônico e seus equipamentos de leitura. Segue abaixo um quadro demonstrativo da evolução que esse PL obteve até sua última atualização, com foco no que diz respeito ao livro eletrônico (grifos nosso): 
Quadro 02: Tramitação do Projeto de Lei 4534/2012

\begin{tabular}{|c|c|c|}
\hline Data & Tramitação & Conteúdo relacionado ao livro eletrônico \\
\hline $11 / 10 / 2012$ & $\begin{array}{l}\text { Apresentação do Projeto de Lei à Câmara } \\
\text { dos Deputados (Mesa Diretora da Câmara } \\
\text { dos Deputados - MESA) }\end{array}$ & $\begin{array}{l}\text { Considera-se livro, para efeitos desta Lei, a publicação de textos } \\
\text { escritos em fichas ou folhas, não periódica, grampeada, colada ou } \\
\text { costurada, em volume cartonado, encadernado ou em brochura, em } \\
\text { capas avulsas, em qualquer forma e acabamento, assim como a } \\
\text { publicação desses textos convertidos em formato digital, } \\
\text { magnético ou ótico, ou impressos no Sistema Braille. } \\
\text { (...) } \\
\S 1^{\circ} \text { São equiparados a livro os seguintes produtos, impressos, } \\
\text { inclusive no Sistema Braille, ou convertidos em formato digital, } \\
\text { magnético ou ótico: } \\
\text { (...) } \\
\text { III - equipamentos cuja função exclusiva ou primordial seja a } \\
\text { leitura de textos em formato digital ou a audição de textos em } \\
\text { formato magnético ou ótico, estes apenas para o acesso de } \\
\text { deficientes visuais. }\end{array}$ \\
\hline $16 / 04 / 2013$ & $\begin{array}{l}\text { Ementa } n^{\circ} 1 / 2013 \text { (Deputada Professora } \\
\text { Dorinha Seabra Resende) }\end{array}$ & $\begin{array}{l}\text { Modifica o inciso III do } \S 2^{\circ} \text { do art. } 2^{\circ} \text { do projeto, para restringir a } \\
\text { equiparação a livro dos equipamentos cuja finalidade } \\
\text { exclusiva ou primordial seja a leitura de textos em formato } \\
\text { digital, de modo a excluir os de plataforma fechada, que só } \\
\text { permitem a utilização de material de empresa fornecedora } \\
\text { específica. }\end{array}$ \\
\hline $16 / 04 / 2013$ & $\begin{array}{l}\text { Ementa } n^{0} 2 / 2013 \text { (Deputada Professora } \\
\text { Dorinha Seabra Resende) }\end{array}$ & $\begin{array}{l}\text { Altera o caput do art. } 2^{\circ} \text { do texto do projeto, para que seja incluída, } \\
\text { no novo conceito sugerido para o livro, a previsão de outros } \\
\text { formatos ou mídias que venham a ser inventados. }\end{array}$ \\
\hline $16 / 04 / 2013$ & $\begin{array}{l}\text { Ementa } n^{\circ} 3 / 2013 \text { (Deputado Marcelo } \\
\text { Almeida) }\end{array}$ & $\begin{array}{l}\text { Altera o inciso III do } \S 2^{\circ} \text { do art. } 2^{\circ} \text { do projeto, para que sejam } \\
\text { equiparados a livro os equipamentos cuja função exclusiva ou } \\
\text { primordial seja a leitura de textos em formato digital, inclusive } \\
\text { os de domínio público. }\end{array}$ \\
\hline $16 / 04 / 2013$ & $\begin{array}{l}\text { Ementa } n^{\circ} 4 / 2013 \text { (Deputado Marcelo } \\
\text { Almeida) }\end{array}$ & $\begin{array}{l}\text { Altera o inciso III do } \S 2^{\circ} \text { do art. } 2^{\circ} \text { do projeto, para propor que os } \\
\text { equipamentos que merecerão a equiparação a livro serão } \\
\text { definidos pelo Poder Executivo. }\end{array}$ \\
\hline $03 / 12 / 2013$ & $\begin{array}{l}\text { Parecer do Relator da Comissão de } \\
\text { Cultura da Câmara dos Deputados }\end{array}$ & $\begin{array}{l}\text { Decide pela aprovação do projeto de lei; pela inclusão do livro } \\
\text { digital no conceito de livro fixado pela Lei } n^{\circ} 10.753 / 2003 \text {; } \\
\text { rejeita as emendas } n^{\circ} 1,3 \text { e } 4 \text {; aprova a Emenda } n^{\circ} 2 \text {. }\end{array}$ \\
\hline $26 / 03 / 2014$ & $\begin{array}{l}\text { Comissão de Cultura da Câmara dos } \\
\text { Deputados }\end{array}$ & $\begin{array}{l}\text { Aprova o requerimento para realização de audiência pública para } \\
\text { discutir o Projeto de Lei 4534/2012. }\end{array}$ \\
\hline $11 / 06 / 2014$ & $\begin{array}{l}\text { Apresentação do parecer da Comissão de } \\
\text { Cultura }\end{array}$ & $\begin{array}{l}\text { Altera a Lei n. } 10.753 \text {, de } 30 \text { de outubro de } 2003 \text {, que "institui a } \\
\text { Política Nacional do Livro", para atualizar a definição de livro e } \\
\text { para alterar a lista de equiparados a livro, e a Lei 11.196, de } 21 \text { de } \\
\text { novembro de 2005, para incluir os equipamentos para leitura } \\
\text { de textos em formato digital no Programa de Inclusão Digital. } \\
\text { Art. } 2^{\circ} \text { Considera-se livro, para efeitos desta Lei, a publicação de } \\
\text { textos escritos em fichas ou folhas, não periódica, grampeada, } \\
\text { colada ou costurada, em volume cartonado, encadernado ou em } \\
\text { brochura, em capas avulsas, em qualquer forma e acabamento, } \\
\text { assim como a publicação desses textos em formato digital, } \\
\text { magnético, ótico, ou em qualquer outro formato ou mídia, e os } \\
\text { impressos no Sistema Braille. } \\
\text { Art. } 2^{\circ} \text { O art. } 28 \text { da Lei n. } 11.196 \text {, de } 21 \text { de novembro de } 2005 \text {, } \\
\text { passa a vigorar com a seguinte redação: } \\
\text { "Art. } 28 \text {. ...... IX - equipamentos para leitura de textos em } \\
\text { formato digital e para audição de textos em formato magnético } \\
\text { ou ótico, classificados nas posições } 8471 \text { e } 8519.81 \text { da Tipi, } \\
\text { produzidos no País conforme processo produtivo básico } \\
\text { estabelecido pelo Poder Executivo. }\end{array}$ \\
\hline $28 / 10 / 2014$ & $\begin{array}{l}\text { Comissão de Cultura, apresentação de } \\
\text { voto em separado do Deputado Onofre } \\
\text { Santo Agostini }\end{array}$ & $\begin{array}{l}\text { Pede para que sejam retirados do Projeto de Lei } 4534 / 2012 \text { os } \\
\text { benefícios fiscais para leitores de livros digitais da Lei no } \\
11.196 / 2005 \text {. }\end{array}$ \\
\hline $20 / 11 / 2014$ & $\begin{array}{l}\text { Parecer do relator da Comissão de } \\
\text { Constituição e Justiça e de Cidadania da } \\
\text { Câmara dos Deputados }\end{array}$ & $\begin{array}{l}\text { Decide por ser inconstitucional a definição de livro do projeto de } \\
\text { lei proposto, a comparação de livro à publicação periódica, assim } \\
\text { como a equiparação de equipamentos para leitura de livro a } \\
\text { livro. }\end{array}$ \\
\hline
\end{tabular}


Continuação

\begin{tabular}{|l|l|l|l|l}
\hline & $\begin{array}{l}\text { A proposição repete erros da Lei n. 10.753, de 30 de outubro de } \\
2003, \text { no que concerne ao livro, e agrega outros. Ela não define um } \\
\text { volume mínimo de caracteres a ser impresso ou utilizado, o que } \\
\text { permitiria no limite transformar qualquer texto em livro, desde que } \\
\text { seja cartonado ou tenha o seu correspondente em formato } \\
\text { digital, magnético ou ótico. A nosso ver, trata-se de proposição } \\
\text { injurídica e inconstitucional, mesmo pela razão que vem de ser } \\
\text { exposta. } \\
\text { Lembremos ainda que a definição de livro da Lei n. 10.753, de 30 } \\
\text { de outubro de 2003, e da proposição em exame, considera-o } \\
\text { publicação não periódica. Ora, por um milagre, e injurídico, as } \\
\text { publicações periódicas passam a ser livro, apenas por mudarem de } \\
\text { meio e destinatários, isto é, pelo projeto, desde que escritas em } \\
\text { Braille, tais publicações se tornam livro. O livro passa a ser } \\
\text { definido não pelo texto que veicula, mas pelo meio que suporta tal } \\
\text { texto. } \\
\text { Por último, a proposição transforma os equipamentos para } \\
\text { leitura de livro em livro. De fato, essa equiparação ofende o } \\
\text { princípio da razoabilidade. }\end{array}$ \\
\hline
\end{tabular}

Fonte: Site da Câmara dos Deputados: http://www.camara.gov.br/proposicoesWeb/fichadetramitacao?idProposicao=556891

Percebe-se que, em quatro anos de debate parlamentar e com a sociedade, no PL 4534/2012 ainda não se encontrou um consenso do que viria a ser livro eletrônico, ou livro digital, como o PL nomeia. A última atualização da tramitação do PL, no site da Câmara dos deputados (BRASIL, 2012), é da Comissão de Constituição e Justiça e de Cidadania responsável pela constitucionalidade de todos os Projetos de Lei da casa -, que afirmou no final de 2014 que o PL está praticamente todo fora da "razoabilidade" e contra princípios constitucionais. Não é de se espantar que um tema relativamente novo e sem um consenso acadêmico e comercial sobre seu conceito gere embates epistemológicos e legais.

É urgente que se defina em lei o que vem a ser o livro eletrônico, para que assim novas políticas de incentivo e produção desse livro sejam realizadas e beneficiem a população. Contudo, é preciso também que essa legalização seja feita de forma coerente e precisa.

Percebe-se que o PL 4534/2012 tenta inserir o leitor de livro eletrônico (e-reader) como algo relacionado e indissociável ao livro eletrônico. Essa modificação seria feita na Lei 11.196/2005 (BRASIL, 2005), que institui programas de incentivo a serviços de tecnologia da informação e inclusão digital, fixa algumas exceções e incentivos fiscais na exportação, fabricação e venda de produtos de tecnologia da informação que estejam enquadrados em alguns requisitos legais, ao visar ao benefício de acesso e uso da população e da Administração Pública a esses tipos de equipamentos ou tecnologias. Segundo a tramitação do PL 4534/2012, feita em 11 de junho de 2014, o artigo 28 da Lei 11.196/2005 seria então alterado para a inserção de "equipamentos para leitura de textos em formato digital", ou seja, os leitores de livro eletrônico (e-readers). Decerto que esse assunto é controverso, tendo em vista a própria definição desses equipamentos de leitura e seus limites. Nem todos esses 
equipamentos são exclusivos para leitura de livros eletrônicos, e alguns deles só aceitam livros eletrônicos com formatos proprietários - como o caso do Kindle da Amazon - o que geraria um incentivo a um tipo de formato proprietário e não de domínio público, como os formatos PDF ou ePub, por exemplo. Por outro lado, torna-se inócua uma lei que defina livro eletrônico e proporcione incentivos à sua produção sem dissertar sobre as formas dessa produção. Como citado por Rodrigues (2014), o livro impresso possui incentivo na sua cadeia de produção, ou seja, desde o fabrico do papel até a sua edição e distribuição. Logo, como se dariam os mesmos incentivos dentro da cadeia produtiva do livro eletrônico? Esse é um desafio que o Congresso Nacional e a sociedade precisam resolver, pois já é fato que o livro eletrônico está inserido no mercado editorial brasileiro.

Dentro da área da Biblioteconomia existem algumas definições mais técnicas, dentre elas a definição normativa de livro na NBR ABNT 6029 - Informação e documentação Livros e folhetos - apresentação (2002), afirma que livro é a "publicação não periódica que contém acima de 49 páginas, excluídas as capas, e que é objeto de Número Internacional Normalizado para Livro (ISBN)" (ASSOCIAÇÃO..., 2002, p. 3). Já no manual de catalogação de Ribeiro (2006), que faz uma grande revisão do Código de Catalogação Anglo Americano segunda edição e do formato MARC (Machine Readable Cataloguing), ambos instrumentos essenciais para a catalogação nacional, diz que livros e folhetos "constituem recursos bibliográficos não seriados, isto é, itens completos em uma só parte, ou que se pretendem completar em um número pré-estabelecido de partes separadas" (RIBEIRO, 2006, p. 2-5). Então, as definições de livro nas áreas afins da CI consideram o livro uma publicação não periódica, com mais de 49 páginas e que possuem o ISBN fornecido pela Biblioteca Nacional. Contudo, não existem normas ou definições técnicas parecidas no que se refere a livros eletrônicos.

Portanto, as definições de livro impresso estão bastante planificadas e normalizadas, tanto no campo legal quanto no acadêmico, o que não ocorre com o livro eletrônico. Como serão os estudos sobre um objeto ou suporte da informação do qual ainda não se tem um consenso sobre sua definição? Como já dito antes, a CI precisa tomar para si esse desafio e trazer para os fóruns de discussão apropriados sobre livros eletrônicos as questões pertinentes ao seu campo científico. Dessa maneira, conforme a definição - ou o próprio devir - de livro eletrônico se torne algo palpável intelectualmente, sem grandes nuances, as unidades de informação, os usuários, os consumidores e os produtores desse tipo de livro poderão interagir de forma saudável, com métodos e planos de negócios mais delineados para um produto intelectual específico: o livro eletrônico. 


\section{PESQUISA EM BIBLIOTECAS UNIVERSITÁRIAS}

De acordo com a seção de metodologia, essa pesquisa teve como amostra, para sua coleta de dados, as bibliotecas das Instituições de Ensino Superior (IES) localizadas no Distrito Federal. Tais tipos de bibliotecas são as chamadas bibliotecas universitárias.

Tendo como referência oficial o site do Ministério da Educação, via Sistema e-Mec, em coleta no mês de junho de 2015, foi possível localizar as 69 Instituições de Ensino Superior em funcionamento atualmente no DF. Segue abaixo a lista retirada do site da instituição.

Tabela 01: Lista das Instituições de Ensino Superior (IES) em funcionamento no DF

\begin{tabular}{|c|c|}
\hline Nome da Instituição de Ensino Superior & Tipo de Instituição \\
\hline Centro Universitário de Brasília (UniCeub) & Centro Universitário \\
\hline Centro Universitário do Distrito Federal (UDF) & Centro Universitário \\
\hline $\begin{array}{l}\text { Centro Universitário do Instituto de Educação } \\
\text { Superior de Brasília - Iesb (Iesb) }\end{array}$ & Centro Universitário \\
\hline $\begin{array}{l}\text { Centro Universitário Estácio de Brasília - Estácio } \\
\text { Brasília (Estácio Brasília) }\end{array}$ & Centro Universitário \\
\hline Centro Universitário Euro-Americano (Unieuro) & Centro Universitário \\
\hline $\begin{array}{l}\text { Centro Universitário Planalto do Distrito Federal - } \\
\text { Uniplan (Uniplan) }\end{array}$ & Centro Universitário \\
\hline Escola de Administração de Brasília (EAB) & Faculdade \\
\hline Escola de Direito de Brasília (EDB) & Faculdade \\
\hline Escola Superior de Ciências da Saúde (ESCS) & Faculdade \\
\hline $\begin{array}{l}\text { Faculdade Associação Internacional de Educação } \\
\text { Continuada: AIEC (AIEC/FAAB) }\end{array}$ & Faculdade \\
\hline Faculdade Albert Einstein (Falbe) & Faculdade \\
\hline Faculdade Anhanguera de Brasília (Fab) & Faculdade \\
\hline $\begin{array}{l}\text { Faculdade Anhanguera de Ciências e Tecnologia de } \\
\text { Brasília }\end{array}$ & Faculdade \\
\hline $\begin{array}{l}\text { Faculdade Anhanguera de Negócios e Tecnologias } \\
\text { da Informação (Facnet) }\end{array}$ & Faculdade \\
\hline Faculdade Anhanguera de Taguatinga & Faculdade \\
\hline Faculdade Apogeu & Faculdade \\
\hline Faculdade Brasiliense de Negócios (FBN) & Faculdade \\
\hline Faculdade Cecap do Lago Norte (Cecap) & Faculdade \\
\hline Faculdade das Águas Emendadas (FAE) & Faculdade \\
\hline Faculdade de Artes Dulcina de Moraes (FADM) & Faculdade \\
\hline Faculdade de Tecnologia CNA (Fatecna) & Faculdade \\
\hline Faculdade de Tecnologia do Transporte & Faculdade \\
\hline Faculdade de Tecnologia Equipe Darwin (FTED) & Faculdade \\
\hline
\end{tabular}




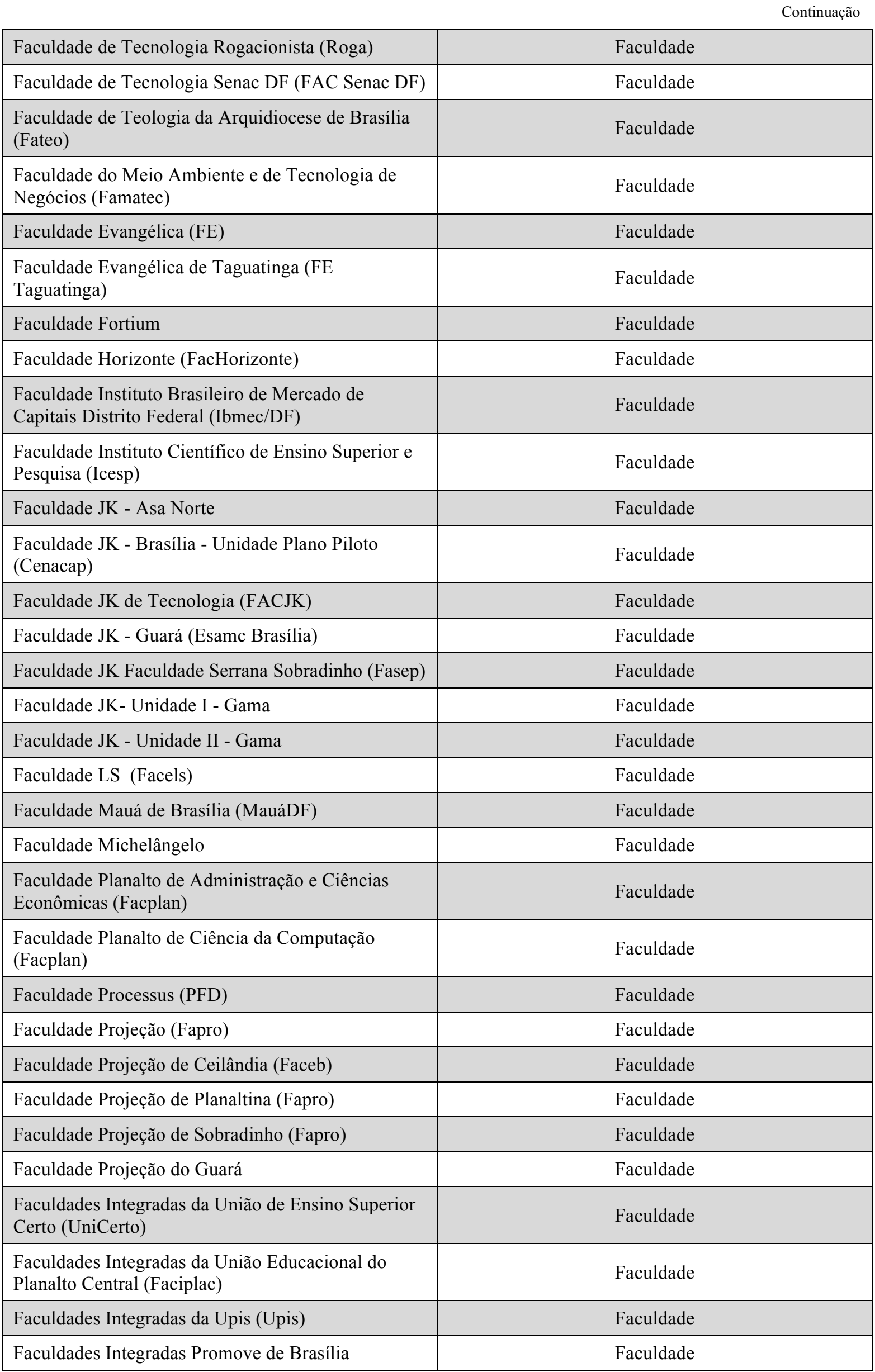




\begin{tabular}{|c|c|}
\hline & Continuação \\
\hline Faculdade Teológica Batista de Brasília (FTBB) & Faculdade \\
\hline IMP de Ensino Superior (IMP) & Faculdade \\
\hline $\begin{array}{l}\text { Instituto de Ciências Exatas (União Educacional de } \\
\text { Brasília - Uneb) }\end{array}$ & Faculdade \\
\hline $\begin{array}{l}\text { Instituto de Ciências Sociais Aplicadas (União } \\
\text { Educacional de Brasília - Uneb) }\end{array}$ & Faculdade \\
\hline $\begin{array}{l}\text { Instituto de Educação e Ensino Superior de } \\
\text { Samambaia (Iesa) }\end{array}$ & Faculdade \\
\hline Instituto de Ensino Superior Planalto (Iesplan) & Faculdade \\
\hline $\begin{array}{l}\text { Instituto Federal de Educação, Ciência e Tecnologia } \\
\text { de Brasília (IFB) }\end{array}$ & Instituto Federal de Educação, Ciência e Tecnologia \\
\hline Instituto Superior de Ciências Policiais (ISCP) & Faculdade \\
\hline $\begin{array}{l}\text { Instituto Superior de Educação Albert Einstein } \\
\text { (ISALB) }\end{array}$ & Faculdade \\
\hline Instituto Superior de Educação do Cecap (Iscecap) & Faculdade \\
\hline $\begin{array}{l}\text { Instituto Superior de Educação Franciscano Nossa } \\
\text { Senhora de Fátima (Fátima) }\end{array}$ & Faculdade \\
\hline $\begin{array}{l}\text { Instituto Superior de Educação Professora Lúcia } \\
\text { Dantas (Isel) }\end{array}$ & Faculdade \\
\hline Universidade Católica de Brasília (UCB) & Universidade \\
\hline Universidade de Brasília (UnB) & Universidade \\
\hline
\end{tabular}

Fonte: Elaboração própria.

Segundo o Ministério da Educação (MEC) e o Decreto no 5.773/06 (BRASIL, 2016; BRASIL, 2006), existem três categorias de Instituições de Ensino Superior no Brasil (IES): faculdade, centro universitário e universidade. A faculdade é a primeira etapa de credenciamento de uma IES perante o MEC. Caso a instituição cumpra alguns quesitos de currículo, abrangência de várias áreas do conhecimento, excelência nos cursos oferecidos e qualificação do corpo do docente, poderá torna-se centro universitário, dependendo da aprovação do MEC.

Já as IES que são consideradas universidades precisam atender os mesmos prérequisitos dos centros universitários, mas com algumas características a mais. Elas precisam ter, pelo menos, um terço de seu corpo docente com titulação acadêmica de mestrado ou doutorado; um terço do corpo docente em regime de tempo integral; aliar ensino, pesquisa e extensão; e apresentar produção intelectual institucionalizada relevante para o domínio e cultivo do saber humano (BRASIL, 2016).

Outro tipo de IES encontrada no DF foi o Instituto Federal de Educação, Ciência e Tecnologia (IF). Ele também é uma IES, mas possui um foco de formação mais tecnológico. Contudo, o Instituto de Brasília também fornece cursos de ensino superior. 
Portanto, é possível perceber que o Distrito Federal não possui uma grande proeminência de centros universitários e universidades, sendo esses tipos de IES a minoria na lista do MEC. Da mesma forma, pode-se esperar do tamanho do acervo e da complexidade de suas bibliotecas universitárias, que atendem parte da missão e exigências legais que as IES como um todo precisam suprir aos alunos, docentes, sociedade e MEC.

Assim, a amostra da pesquisa foi previamente determinada pelos dados acima informados pelo MEC. Para atingir o objetivo geral da pesquisa, decidiu-se pelo questionário como método de coleta de dados; ele está transcrito no Apêndice B e foi feito na ferramenta Google Forms ${ }^{\circledR}$. Essa ferramenta permite o envio do questionário online, além de fornecer a coleta já em formato de dados estruturados e ter ferramentas de controle de resposta, como, por exemplo, a permissão de apenas uma resposta por pesquisado.

O pré-teste da pesquisa foi realizado em outubro de 2015 com uma biblioteca universitária de uma faculdade do DF (disponível no Apêndice A). Essa primeira amostra trouxe resultados positivos em relação ao conhecimento dos livros eletrônicos pelo bibliotecário respondente e o conhecimento do fato da biblioteca possuir esse tipo de livro em seu acervo. Contudo, ficaram perceptíveis algumas limitações com a relação entre revisão de literatura e os indicadores encontrados no questionário, além de não haver perguntas que definissem um perfil das bibliotecas universitárias. Esse primeiro questionário possuía 21 perguntas, das quais 16 eram do tipo fechada e 5 do tipo aberta. Para atingir os objetivos específicos da pesquisa, verificou-se a necessidade de retirar algumas questões abertas e aumentar o número de questões fechadas.

Para obter os dados de envio das IES selecionadas no site do MEC, foi realizada uma pesquisa na Internet, dentro dos portais das instituições em busca de endereços de e-mail de suas bibliotecas. Nesse momento houve alguma dificuldade na coleta desses dados, algumas instituições não possuem sites na internet, ou não possuem dados completos de suas bibliotecas disponíveis em seus portais. Logo, foi necessário realizar contato pessoal via telefone para mais de dez IES que não possuíam os e-mails de suas bibliotecas informado em seus portais.

A primeira lista de contatos localizados das IES listadas acima relacionou um total de 47 instituições confirmadas, nos sites ou via telefone; ou seja, a amostra caiu de 69 IES listadas no site do MEC para 47 IES localizadas pela internet ou por telefone. Várias dessas IES já estão fechadas, ou foram interditadas pelo próprio MEC ou estavam em reforma.

Em 05 de dezembro de 2015, a primeira remessa de questionários via e-mail foi enviada para as 47 IES listadas e confirmadas. Desse total, 06 e-mails retornaram, com 
problemas de inexistência ou erro do endereço de e-mail. Apenas 3 IES responderam aos questionários nesse primeiro momento.

Após um mês, uma segunda tentativa de envio dos questionários foi feita. Dessa vez foram enviados 38 e-mails com os questionários. Nesse segundo momento, mais 4 IES responderam ao questionário. A partir de então, todas as bibliotecas das IES que faltavam responder ao questionário - 34 instituições - foram contatadas novamente por telefone, com o intuito de reforçar a importância do preenchimento do questionário, assim como explicar a relevância da pesquisa, a fim de obter maior índice de respostas. Em 12 de fevereiro de 2016, demos a pesquisa por encerrada, com 14 questionários respondidos pelas IES - dentre elas, todas as instituições públicas do DF, todas as universidades e a maioria dos centros universitários.

Logo, diante da amostra selecionada para a pesquisa, o índice de respostas foi de $34,15 \%$ - 14 questionários respondidos em um universo de 41 IES. A coleta de dados, por meio do questionário, durou 4 meses. Importa ressaltar que foi solicitado que apenas um questionário por biblioteca fosse respondido. Segue abaixo a tabela que demonstra as IES que responderam ao questionário.

Tabela 02: Lista das bibliotecas que responderam ao questionário

\begin{tabular}{|l|c|}
\hline \multicolumn{1}{|c|}{ Nome da Instituição de Ensino Superior } & Tipo de Instituição \\
\hline Centro Universitário de Brasília (UniCeub) & Centro Universitário \\
\hline Centro Universitário do Distrito Federal (UDF) & Centro Universitário \\
\hline $\begin{array}{l}\text { Centro Universitário do Instituto de Educação } \\
\text { Superior de Brasília (Iesb) }\end{array}$ & Centro Universitário \\
\hline Centro Universitário Euro-Americano (Unieuro) & Centro Universitário \\
\hline $\begin{array}{l}\text { Centro Universitário Planalto do Distrito Federal } \\
\text { (UNIPLAN) }\end{array}$ & Centro Universitário \\
\hline Escola de Direito de Brasília (EDB) & Faculdade \\
\hline Escola Superior de Ciências da Saúde (ESCS) & Faculdade \\
\hline $\begin{array}{l}\text { Faculdade Associação Internacional de Educação } \\
\text { Continuada: AIEC (AIEC/FAAB) }\end{array}$ & Faculdade \\
\hline Faculdade Anhanguera de Brasília (FAB) & Faculdade \\
\hline $\begin{array}{l}\text { Faculdade Instituto Brasileiro de Mercado de } \\
\text { Capitais Distrito Federal (Ibmec/DF) }\end{array}$ & Faculdade \\
\hline Faculdade Projeção (FAPRO) & Instituto Federal de Educação, Ciência e Tecnologia \\
\hline $\begin{array}{l}\text { Instituto Federal de Educação, Ciência e Tecnologia } \\
\text { de Brasília (IFB) }\end{array}$ & Universidade \\
\hline Universidade Católica de Brasília (UCB) & Continua \\
\hline
\end{tabular}


Continuação

\begin{tabular}{|l|l|}
\hline Universidade de Brasília (UNB) & Universidade \\
\hline
\end{tabular}

Fonte: Elaboração própria.

A ferramenta de pesquisa - o questionário - foi elaborada tendo como base os modelos fornecidos por Serakan (2003). Ele foi elaborado em 04 seções ou blocos de questões, quais sejam: 01) sobre o bibliotecário; 02) livros eletrônicos; 03) sobre a biblioteca; 04) sobre a coleção de livros eletrônicos da biblioteca. Importa ressaltar que foi informado aos respondentes que o sigilo de suas identidades seria mantido. Todas essas seções tentaram, em algum momento, suprir os objetivos específicos da pesquisa, como visto abaixo:

Quadro 03: Relação dos objetivos específicos com os blocos de questões do questionário

\begin{tabular}{|l|c|c|c|c|}
\hline \multicolumn{1}{|c|}{ Objetivos } & $\begin{array}{c}\text { Identificar os } \\
\text { principais } \\
\text { específicos } \\
\text { conceitos de } \\
\text { livros impresso e } \\
\text { livros eletrônicos de } \\
\text { na literatura e } \\
\text { traçar um } \\
\text { comparativo } \\
\text { entre eles. }\end{array}$ & $\begin{array}{c}\text { Mapear quais } \\
\text { bibliotecas } \\
\text { universitárias do } \\
\text { DF possuem } \\
\text { coleções de livros } \\
\text { eletrônicos. }\end{array}$ & $\begin{array}{c}\text { Identificar como } \\
\text { os bibliotecários } \\
\text { das bibliotecas } \\
\text { universitárias do } \\
\text { DF conceituam e } \\
\text { definem livro } \\
\text { eletrônico. }\end{array}$ & $\begin{array}{c}\text { Apontar quais os } \\
\text { conceitos de livro } \\
\text { eletrônico } \\
\text { utilizados pelas } \\
\text { bibliotecas } \\
\text { universitárias do } \\
\text { DF. }\end{array}$ \\
\hline $\begin{array}{l}\text { 01) Sobre o bibliotecário } \\
\text { books }\end{array}$ & & $\mathbf{X}$ & $\mathbf{X}$ & $\mathbf{X}$ \\
\hline 03) Sobre a biblioteca & $\mathbf{X}$ & $\mathbf{X}$ & $\mathbf{X}$ \\
\hline $\begin{array}{l}\text { 04) Sobre a coleção de } \\
\text { livros eletrônicos da } \\
\text { biblioteca }\end{array}$ & & & & $\mathbf{X}$ \\
\hline
\end{tabular}

Fonte: Elaboração própria.

O questionário contou com 42 perguntas, onde 39 foram do tipo fechada e 03 do tipo aberta, seguindo a metodologia mista escolhida para a pesquisa. As perguntas abertas foram elaboradas com o intuito de perceber qual a definição de livros eletrônicos os bibliotecários e as bibliotecas utilizam. Ao final do questionário também foi elaborada uma pergunta aberta solicitando aos bibliotecários responderem qual a importância do livro eletrônico para as bibliotecas universitárias. 


\section{ANÁLISE DOS RESULTADOS}

Os resultados obtidos com os 14 questionários respondidos foram analisados por meio de estatística inferencial simples. Os dados foram processados em planilha de dados Excel $\mathbb{R}$.

A primeira seção de perguntas do questionário teve como objetivo traçar um perfil do bibliotecário respondente, ou do bibliotecário de bibliotecas universitárias da amostra. Essa primeira seção também observou a relação que esses bibliotecários possuem com os livros eletrônicos.

Foi constatado que a grande maioria dos profissionais são mulheres: 10 dos 14 respondentes. Outro importante dado foi o índice de formação acadêmica dos bibliotecários: a grande maioria possui nível de escolaridade de pós-graduação. As informações de idade revelaram que é predominante entre os bibliotecários a faixa etária de 20 a 30 anos, ou seja, são profissionais jovens e em início de carreira.

\section{Gráfico 01: Idade do bibliotecário}

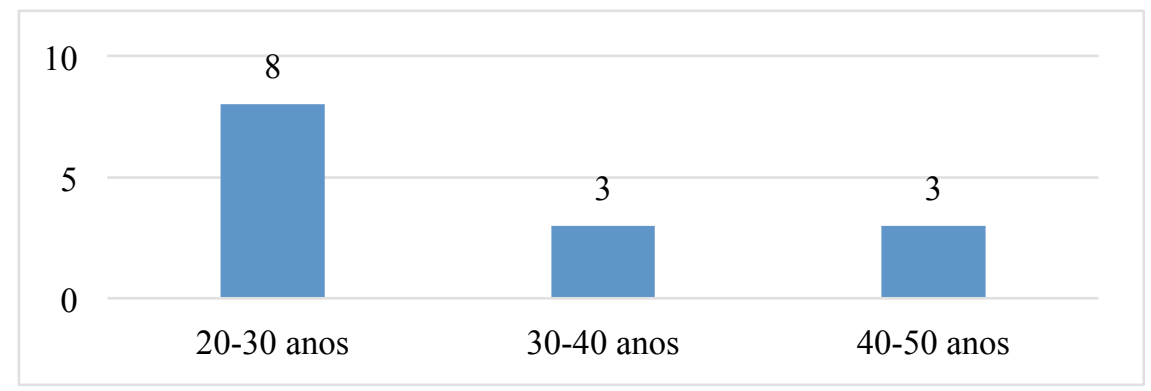

Fonte: Elaboração própria.

Gráfico 02: Gênero do bibliotecário

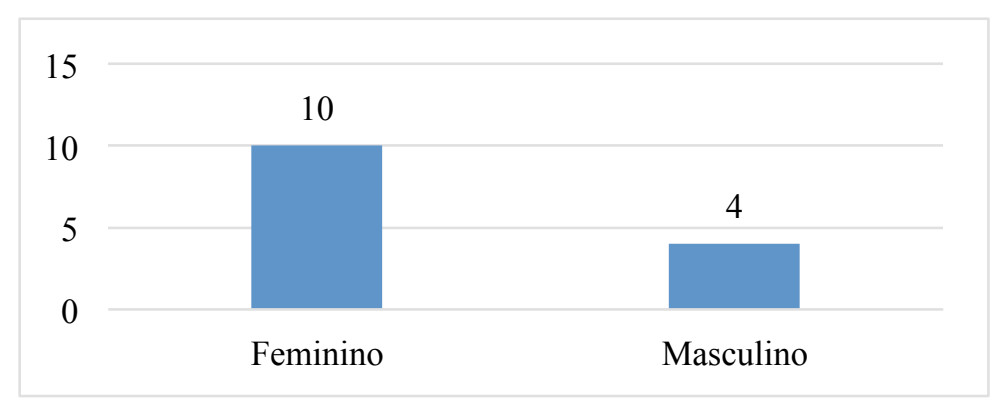

Fonte: Elaboração própria. 
Gráfico 03: Formação do bibliotecário

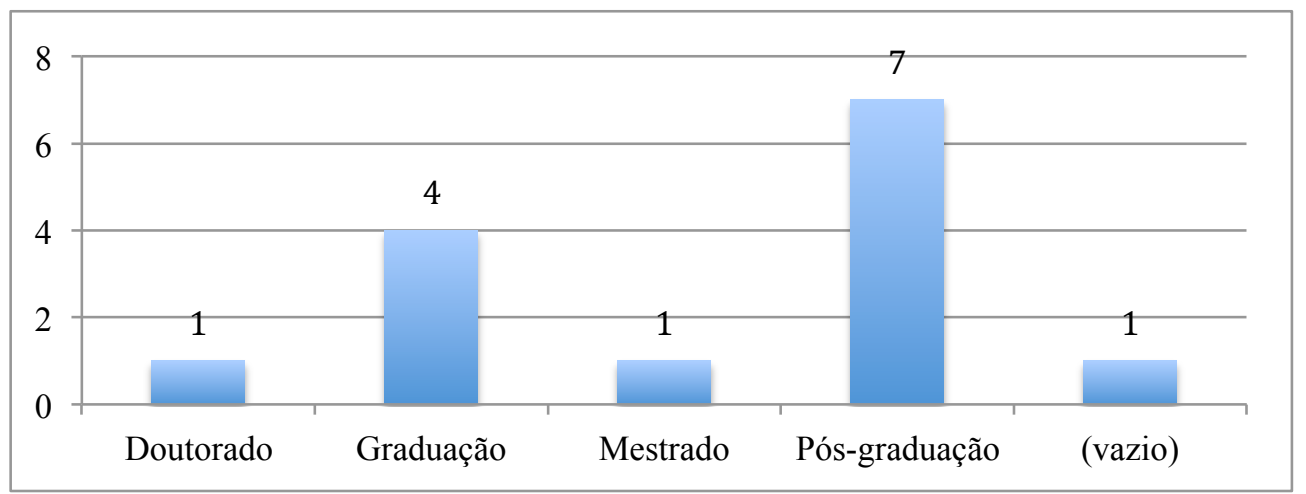

Fonte: Elaboração própria.

As perguntas da segunda seção tratam da forma como o bibliotecário enxerga e lida com o livro eletrônico. Tais perguntas se mostraram necessárias tendo em vista que a experiência particular e acadêmica do profissional da informação pode modificar a realidade da biblioteca em que ele trabalha.

Gráfico 04: Um livro impresso quando digitalizado é um livro eletrônico?

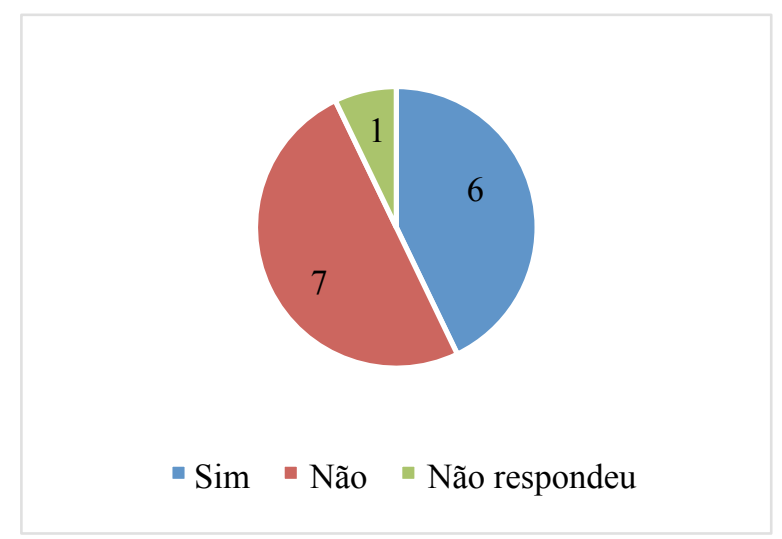

Fonte: Elaboração própria.

Gráfico 05: Quais formatos de livro eletrônico o bibliotecário conhece

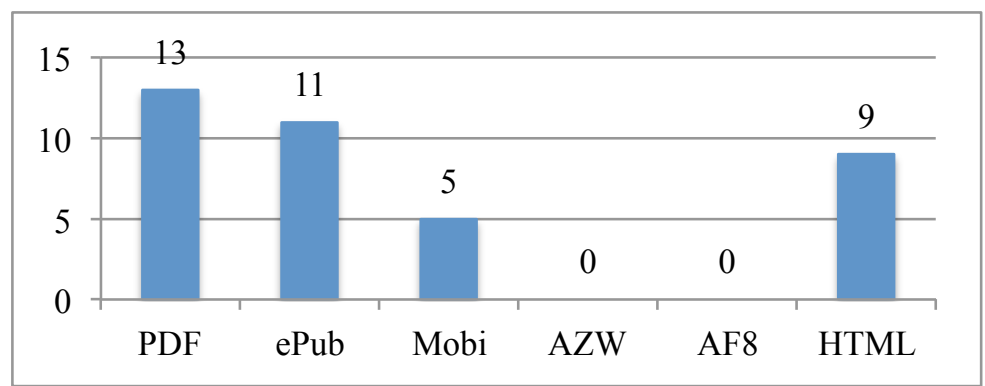

Fonte: Elaboração própria. 
Gráfico 06: Existe diferença entre livro eletrônico e livro digital?

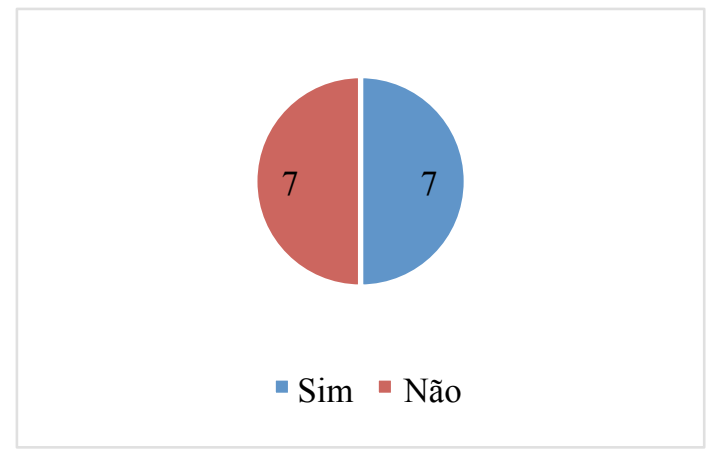

Fonte: Elaboração própria.

Gráfico 07: Você já leu um livro eletrônico?

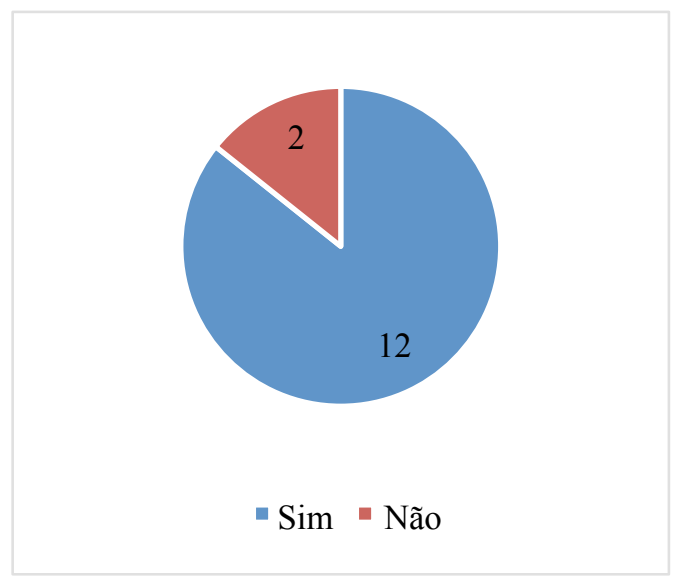

Fonte: Elaboração própria.

Gráfico 08: Você já adquiriu um livro eletrônico em uma livraria?

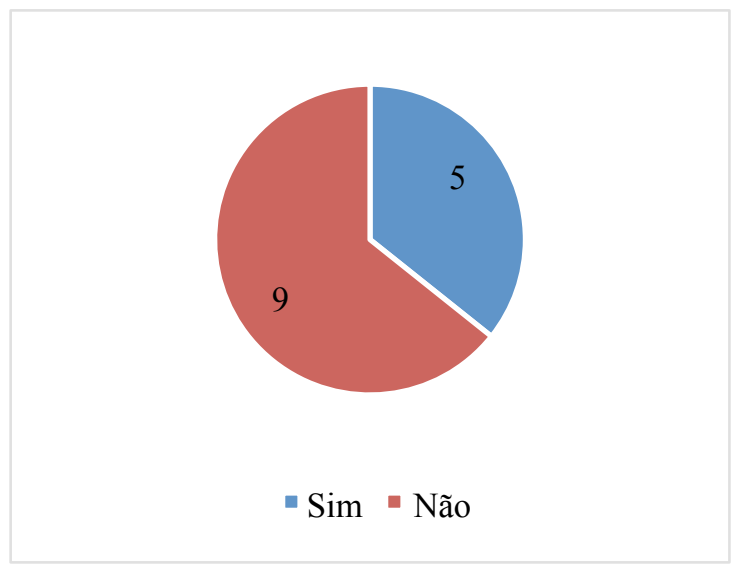

Fonte: Elaboração própria.

Pode-se perceber que não há um consenso quanto à definição de livro eletrônico, ou quanto à sua nomenclatura - diante das perguntas acima. Quase metade dos bibliotecários 
consideram livro eletrônico o livro físico digitalizado, e quase metade não o considera. Logo a seguir, perguntou-se se haveria para eles a diferenciação entre livro digital e livro eletrônico. Segundo a revisão de literatura, Grau, Oddone e Dourado (2013) consideram que existe diferença entre essas duas nomenclaturas, e uma das características que os diferenciam, principalmente, seria a forma de acesso a esses documentos. Enquanto o livro eletrônico seria aquele livro acessível apenas por dispositivos dedicados, com plataformas específicas, o livro digital seria todo aquele passível de ser lido em qualquer dispositivo de processamento dados; ou seja, as perguntas a essas respostas podem estar de acordo com a definição das autoras, já que os livros digitalizados, normalmente, ficam em formato PDF, e seriam - segundo Grau, Oddone e Dourado - livros digitais. Logo, pode-se perceber uma coerência entre as respostas às duas perguntas.

Sobre o conhecimento acerca dos livros eletrônicos pelos bibliotecários, as respostas foram satisfatórias. A grande maioria dos bibliotecários responderam que já leram um livro eletrônico em algum momento, apesar da minoria já ter adquirido algum em sites ou livrarias. É possível corroborar esse fato com as respostas sobre o conhecimento de formatos de livros eletrônicos. Apenas os formatos proprietários da Amazon, o AZW e o AF8, não são conhecidos por qualquer bibliotecário - importa ressaltar que esses formatos são bastante recentes e não muito desenvolvidos, sendo o Mobi o formato mais difundido pela Amazon. Percebe-se que os formatos abertos são os mais conhecidos, nesta ordem: PDF, ePub e HTML. Conhecer os formatos não quer dizer, necessariamente, que os bibliotecários já leram livros eletrônicos nesses formatos. Contudo, saber quais são os formatos de livros eletrônicos demonstra algum ganho de conhecimento desses profissionais. Talvez se possa afirmar que o conhecimento e a popularidade de um formato estejam relacionados ao fato dele ser aberto ou proprietário. Essa característica pode ser muito importante na formação de uma coleção de livros eletrônicos de uma biblioteca, tendo em vista a continuidade do acesso e o barateamento de seu processamento.

Houve, ainda na segunda seção, a pergunta aberta sobre o que seria um livro eletrônico para o bibliotecário respondente. Todos os bibliotecários responderam:

\section{Quadro 04: O que é um livro eletrônico?}

\begin{tabular}{|l|}
\hline \multicolumn{1}{|c|}{ O que é um livro eletrônico, para você? } \\
\hline É um conteúdo informacional em formato ou dispositivo digital. \\
\hline Uma obra de caráter monográfico em suporte eletrônico. \\
\hline $\begin{array}{l}\text { Material monográfico de mais de } 49 \text { páginas disponibilizada em meio digital, em diferentes formatos } \\
\text { e plataformas, com entidades responsáveis por sua publicação e autoria. }\end{array}$ \\
\hline
\end{tabular}


Continuação

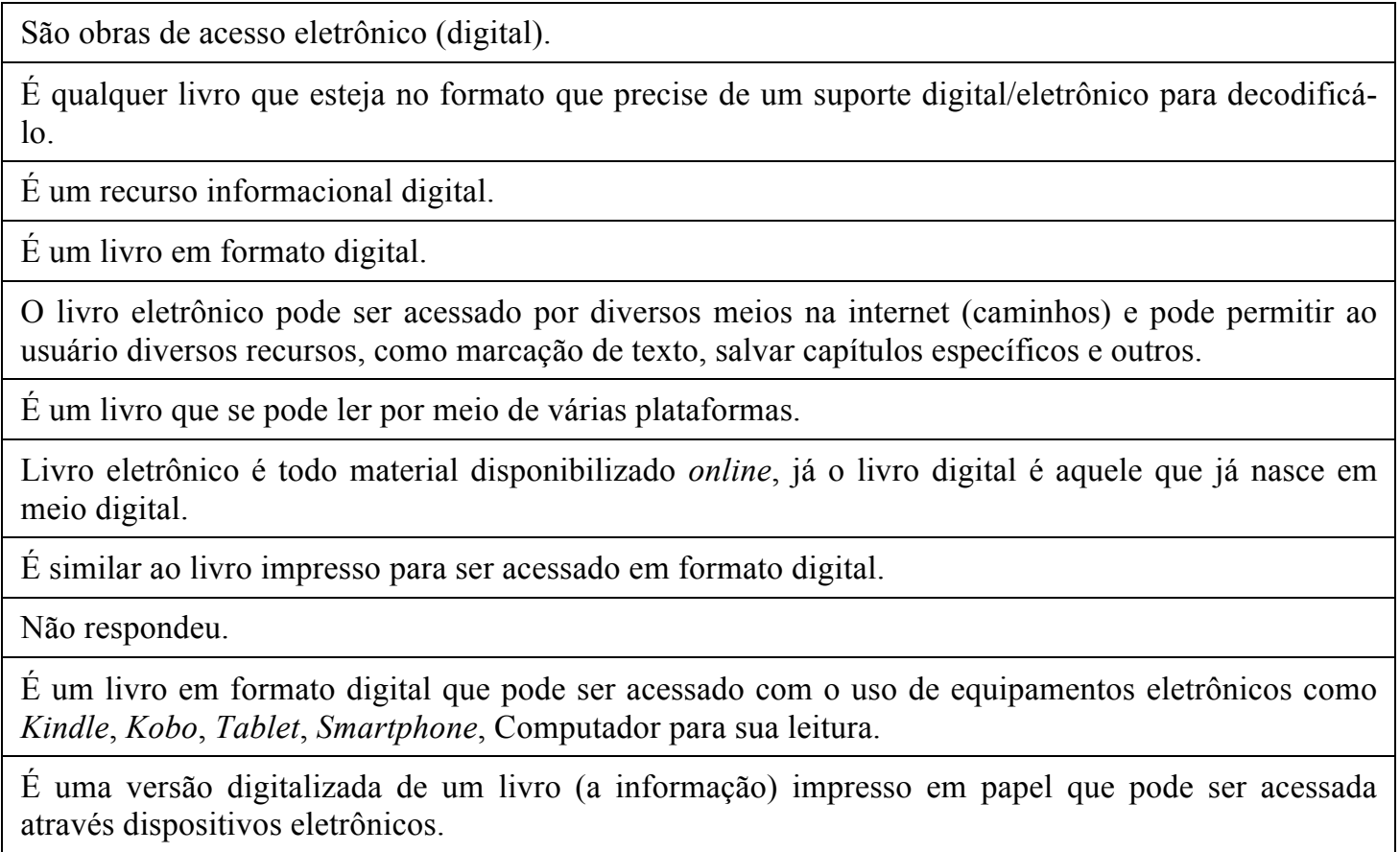

Fonte: Elaboração própria.

Para analisar as respostas, escolhemos seis categorias que podem ajudar na definição de livro eletrônico, de acordo com a revisão de literatura (VASSILOU; ROWLEY, 2008; GRAU; ODDONE; DOURADO, 2013). De acordo com as autoras, as categorias que podem ajudar na definição de um livro eletrônico seriam: sua natureza digital ou eletrônica; alusão ao conhecimento de livro impresso; indicação da natureza do conteúdo do livro eletrônico; referência sobre a tecnologia do conteúdo do livro eletrônico; o tipo de plataforma ou dispositivo utilizado para seu acesso, se dedicada ou não.

Após uma tabulação das respostas, foi possível perceber que os bibliotecários da amostra tendem a definir livros eletrônicos principalmente dentro das categorias de "natureza digital ou eletrônica" e da "referência sobre a tecnologia do conteúdo do livro eletrônico", seguida pelas categorias de que livro eletrônico seria um livro que pudesse ser lido em qualquer plataforma de processamento de dados, e da categoria que faz alusão à comparação ao livro impresso. As categorias menos citadas foram a "indicação da natureza do conteúdo do livro eletrônico" e sobre a questão da plataforma dedicada, os formatos proprietários de livro eletrônico. Segue abaixo uma análise das principais categorias escolhidas pelos bibliotecários: 
Quadro 05: Definições de livro eletrônico por categorias

\begin{tabular}{|l|c|}
\hline \multicolumn{1}{|c|}{ Categorias } & $\begin{array}{c}\text { Número de definições } \\
\text { que citaram a categoria }\end{array}$ \\
\hline Indicação da natureza do conteúdo do livro eletrônico & 2 \\
\hline Lido apenas em plataforma dedicada & 5 \\
\hline Alusão ao conhecido de livro impresso & 10 \\
\hline Lido em qualquer plataforma de processamento de dados & 11 \\
\hline Referência sobre a tecnologia do conteúdo do livro eletrônico & 12 \\
\hline Natureza digital ou eletrônica & 12 \\
\hline
\end{tabular}

Fonte: Elaboração própria.

Dessa forma, pode-se afirmar que os bibliotecários enxergam o livro eletrônico como um livro similar ao livro impresso, mas que está disponível para leitura em meio digital ou eletrônico, de preferência, em uma plataforma não dedicada. Eles não se apegaram às novas funcionalidades que o livro eletrônico permite aos seus leitores, como tecnologias de marcação, de busca de conteúdo, de multimídia, de tradução, dentre outras; assim como não deram muita ênfase na questão das plataformas dedicadas, mais vistas em livros eletrônicos com formatos proprietários ou específicos.

Ao final da segunda seção de perguntas, foi questionado ao bibliotecário se ele já havia comparecido em algum congresso ou evento da área de Ciência da Informação com a temática sobre livros eletrônicos. O resultado não foi muito satisfatório: apenas um bibliotecário respondeu que sim; ou seja, mesmo que esses profissionais estejam se informando sobre o tema por meio de comunicações científicas, livros ou demais fontes de informação, não ocorre entre esse grupo um compartilhamento de informações em eventos sobre livros eletrônicos. Isso pode refletir na forma como a definição e a gestão desses livros estão sendo feitas nessas instituições, além de alertar a comunidade da CI para o fato de que, embora haja fóruns de discussão sobre o tema, ele não está sendo muito preenchido pelos bibliotecários de bibliotecas universitárias de Brasília.

A terceira seção de perguntas focou no perfil da biblioteca estudada. Foi identificado que a maioria das bibliotecas da amostra são de porte médio para pequeno, no que tange ao tamanho de seu acervo físico. Como se pode observar no gráfico abaixo, apenas 4 bibliotecas das 14 estudadas possuem mais de 100.000 itens em seus acervos. Quando questionadas qual era o tipo de biblioteca, 10 respondem que eram privadas e 4 responderam que eram públicas. 
Gráfico 09: Tamanho do acervo da biblioteca

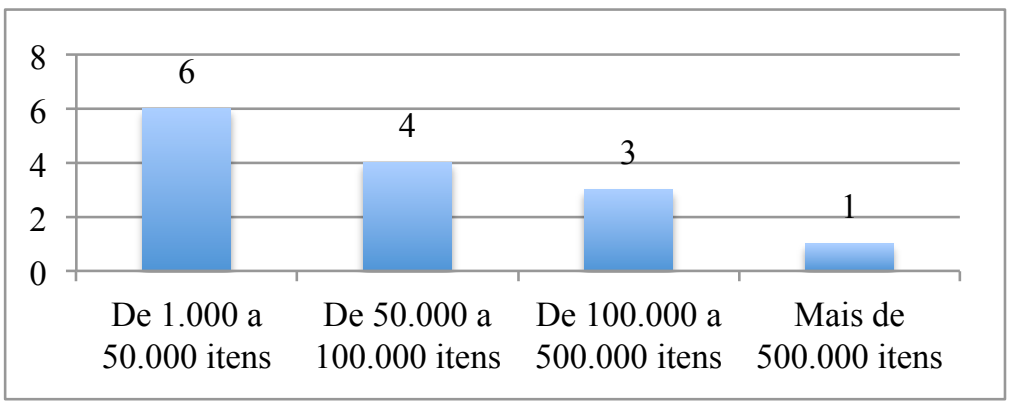

Fonte: Elaboração própria.

Para identificar quais os assuntos predominantes nos acervos dessas bibliotecas, foi apresentada no questionário uma pergunta que pedia aos respondentes que marcassem quais áreas do conhecimento seus acervos abrangem. O critério seguido foi a divisão das áreas de conhecimento da Capes, por abranger de uma forma mais geral e completa todos os temas de pesquisa e estudos universitários do país. Era esperado que os acervos dessas bibliotecas fossem bem representativos em várias dessas áreas do conhecimento, tendo em vista se tratar de bibliotecas universitárias e essa ser uma de suas características. Contudo, os assuntos que mais surgiram nos acervos foram: Ciências Sociais Aplicadas, Ciências Humanas e Ciências da Saúde; seguidas de Ciências Exatas e da Terra, Ciências Biológicas e Linguística, Letras e Artes. Os assuntos menos presentes são Engenharias e Ciências Agrárias; ou seja, da amostra pesquisada, a predominância do acervo indica quais são os cursos mais dominantes nessa IES, cursos, em sua maioria, relacionados aos três primeiros temas mais marcados nessa questão. Isso pode refletir, futuramente, os tipos de bases de dados de livros eletrônicos que essas bibliotecas estão escolhendo de acordo com essas necessidades. 
Gráfico 10: Áreas de conhecimento do acervo

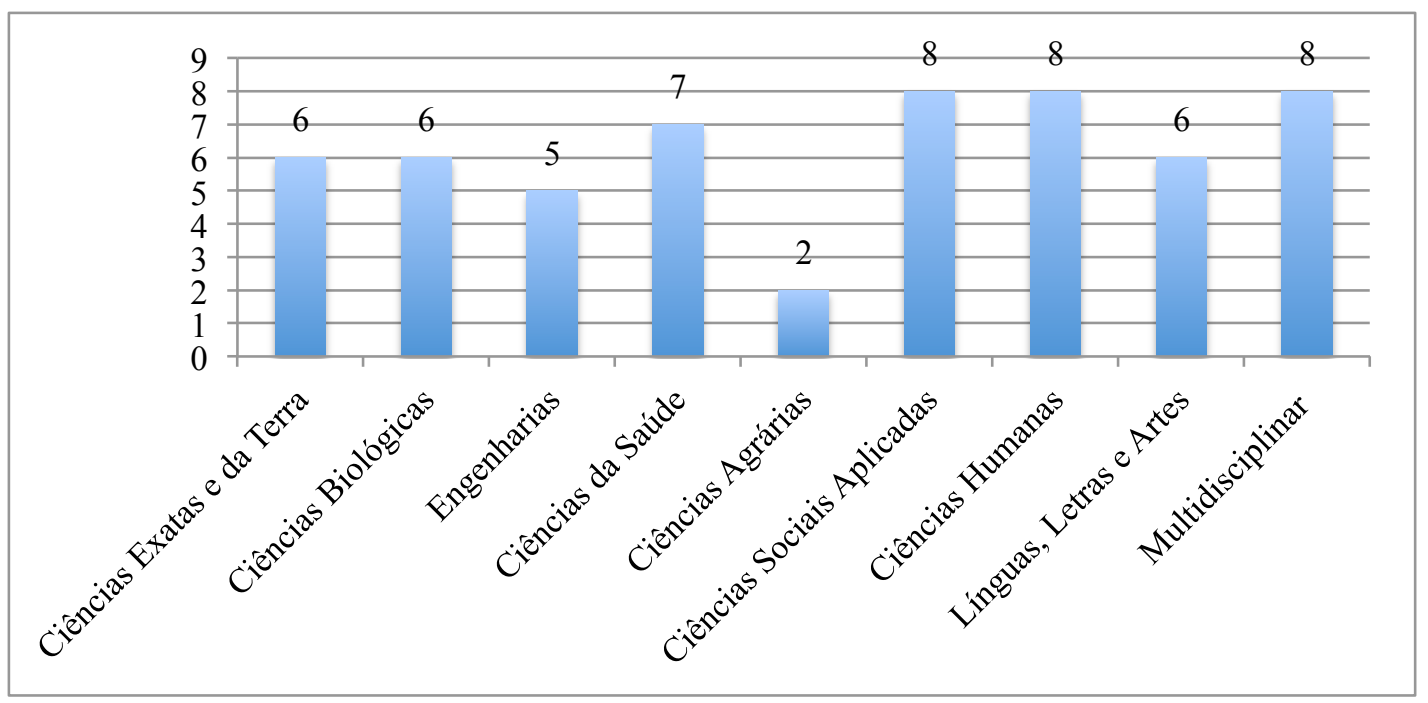

Fonte: Elaboração própria.

Outra informação solicitada aos respondentes foi sobre o sistema de informação utilizado na biblioteca. As respostadas demonstraram que 50\% usam o software Pergamum para gerenciar seus dados e serviços de informação. Apenas uma biblioteca possui um sistema próprio, e as demais possuem outros tipos de sistema encontrados no mercado.

\section{Gráfico 11: Sistemas utilizados na biblioteca}

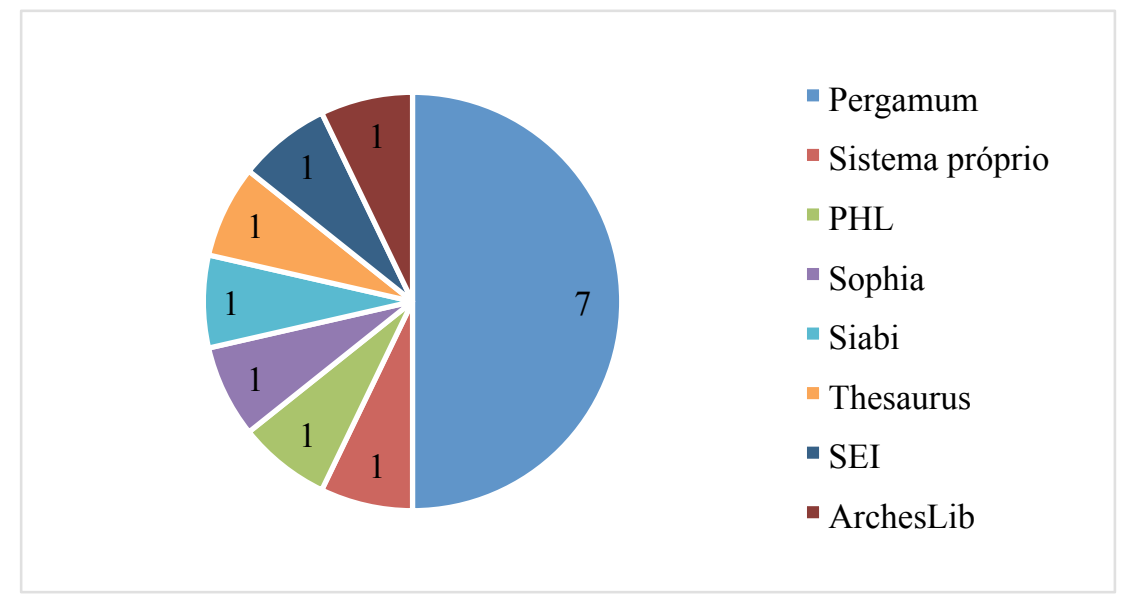

Fonte: Elaboração própria.

Sobre a questão do público da biblioteca, percebe-se que a maioria das bibliotecas atendem de 1.000 a 3.000 usuários por mês; 4 que atendem de 200 a 500 usuários; outras 3 atendem mais de 3.000 usuários; e 2 atendem de 500 a 1.000 usuários. Isso significa que, em 
geral, o número de usuários atendidos por essas instituições é bem diversificado, sendo que muitos usuários são atendidos por mês em todas elas. Isso demonstra, mais uma vez, a importância da biblioteca universitária dentro do campus e da vida acadêmica dos envolvidos nas IES.

Para analisar quais são esses usuários atendidos, perguntamos também qual a característica do usuário atendido. Sobre a forma de acesso à biblioteca, quase $50 \%$ das instituições responderam que o acesso pode ser feito por qualquer usuário; 4 responderam que só usuários pertencentes à instituição têm acesso à biblioteca; outras 3 responderam que o acesso é restrito apenas a usuários previamente cadastrados. Esse resultado refletiu na forma de acesso ao acervo também, pois nem sempre os usuários das instalações físicas da biblioteca têm acesso ao acervo.

Além do acesso ao acervo, foi questionado quantos terminais a biblioteca possui para consultas gerais. Das 14 bibliotecas que responderam, 6 possuem de 3 a 10 terminais; 5 possuem mais de 10 terminais; e apenas 3 instituições possuem até 3 terminais. Nesse item foi possível relacionar que as bibliotecas que mais têm terminais são aquelas que possuem um acervo maior e mais atendem usuários por mês, o que se mostra bem coerente.

Gráfico 12: Número de terminais disponíveis na biblioteca

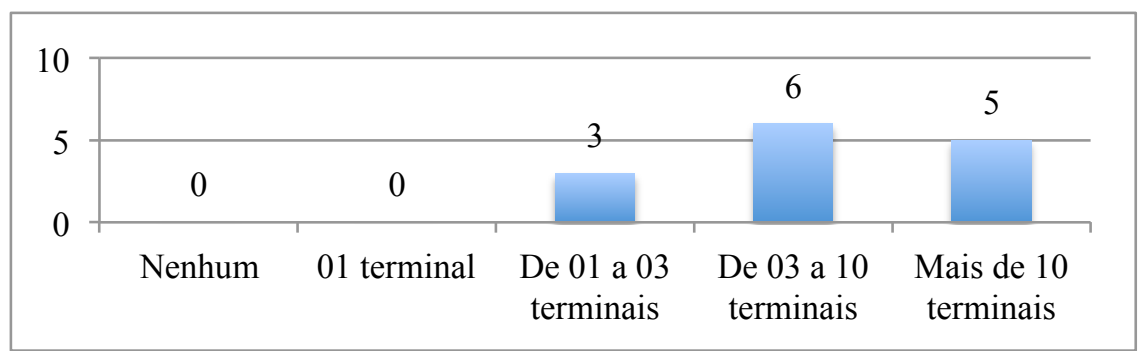

Fonte: Elaboração própria.

Gráfico 13: Número de usuários por mês da biblioteca

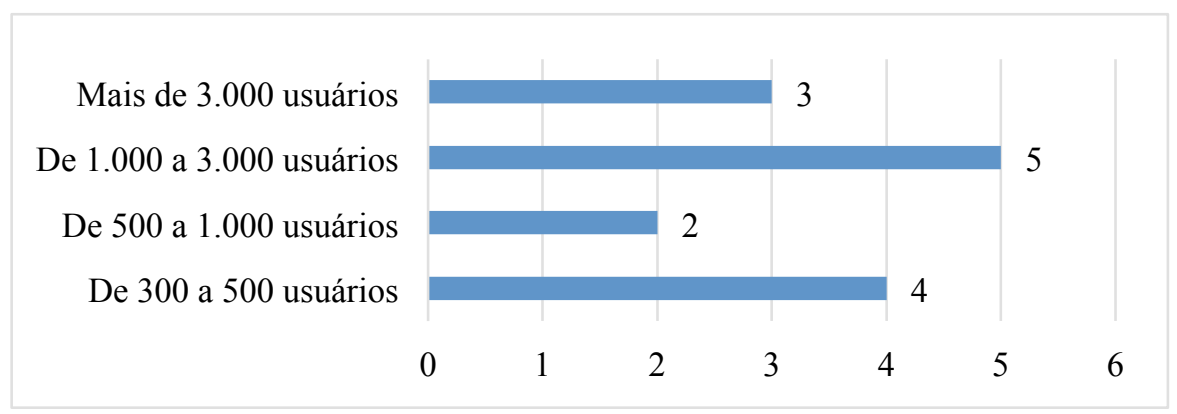

Fonte: Elaboração própria. 
A última análise feita sobre o perfil da biblioteca foi saber da disponibilização de bases de dados de conteúdo digital e identificar quais delas possuem livros eletrônicos em seu acervo. Das 14 bibliotecas, 13 possuem bases de dados de conteúdo digital disponível para seus usuários; destas, 12 afirmaram disponibilizar livros eletrônicos em sua base de dados. Das duas bibliotecas que não possuem livros eletrônicos disponíveis para seus usuários, uma disse ter pretensão de disponibilizá-los no futuro; e uma não possui essa intenção.

\section{Gráfico 14: Base de dados de conteúdo digital}

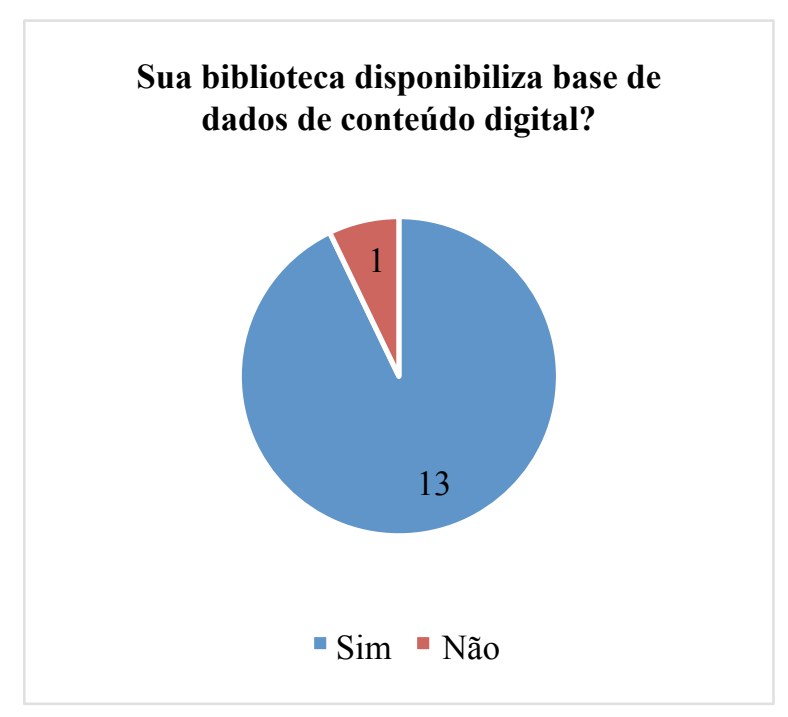
Caso positivo, são disponibilizados livros eletrônicos nestas bases de conteúdo digital?

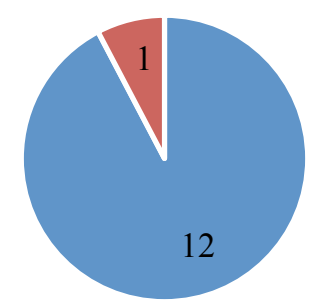

- Sim $"$ Não

Se não há disponibilização de livros eletrônicos na sua biblioteca, existe alguma previsão para que esse serviço seja implementado?

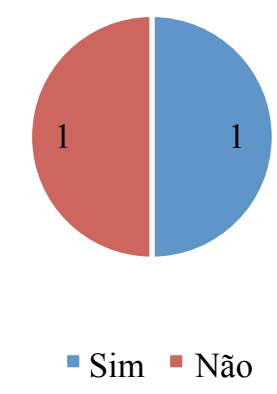

Fonte: Elaboração própria.

Para completar o perfil dessas bibliotecas, foi perguntado às que possuem base de dados de livros eletrônicos quantos terminais na biblioteca são disponibilizados aos seus usuários para o acesso a esse tipo de livro. A maioria das bibliotecas responderam que 
possuem mais de 10 terminais para esse fim. Esse dado teve uma discrepância com os dados do gráfico 12, que revelam o número de terminais de uma forma geral na biblioteca. Talvez aqui esses terminais sejam específicos para acesso a esse tipo de acervo, ou se trate de terminais de laboratório de informática montados para esse fim exclusivo.

\section{Gráfico 15: Quantos terminais de consulta com acesso a livros eletrônicos ou acervo digital existem disponíveis ao usuário?}

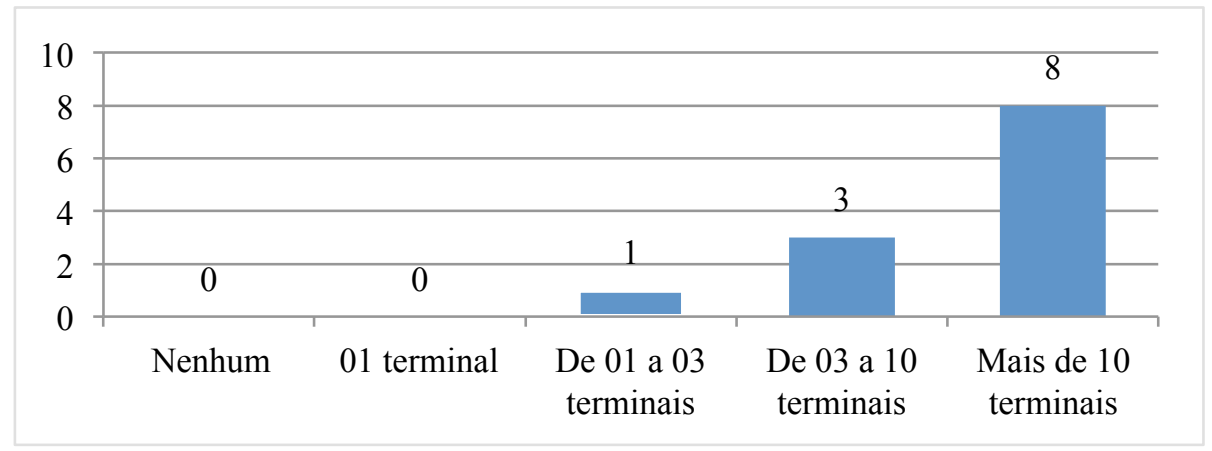

Fonte: Elaboração própria.

A seção 4 do questionário trata especificamente da coleção de livros eletrônicos dessas bibliotecas. Portanto, deveriam responder essa parte apenas 12 das 14 bibliotecas pesquisadas: aquelas que afirmaram possuir livros eletrônicos em suas bases. Enquanto 4 bibliotecas afirmaram possuir livros eletrônicos em suas coleções há dois, há três ou há quatro anos, 3 responderam que os possuem há menos de 1 ano. Contudo, um pouco mais da metade possui esse tipo de livro há mais de 4 anos em seu acervo, num total de 7 bibliotecas. Logo, pode-se perceber que o livro eletrônico já não é mais uma novidade nesse tipo de biblioteca da amostra.

Gráfico 16: Há quanto tempo a biblioteca possui uma coleção de livros eletrônicos.

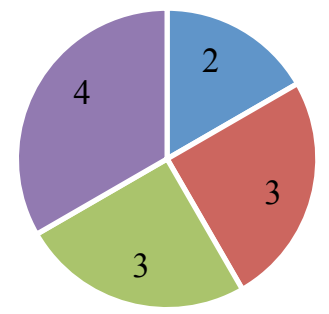

- 1 a 2 anos

- Menos de 01 ano

- Mais de 6 anos

- 2 a 4 anos

Fonte: Elaboração própria 
Sobre o tipo de acesso aos livros eletrônicos, ou formas de proteção ao seu conteúdo, a maioria das bibliotecas possui esse tipo de livro com acesso aberto, sem restrições de direitos autorais, enquanto 02 delas responderam que possuem apenas livros eletrônicos de acesso restrito e 04 afirmaram que possuem os dois tipos de livro eletrônico. Aqui é possível perceber o predomínio dos livros eletrônicos que não possuem restrição de acesso, o que talvez possa ser explicado pelo modelo de mercado deste tipo de livro e outras dificuldades que serão analisadas mais à frente, no gráfico 25 .

\section{Gráfico 17: Tipo de acesso aos livros eletrônicos}

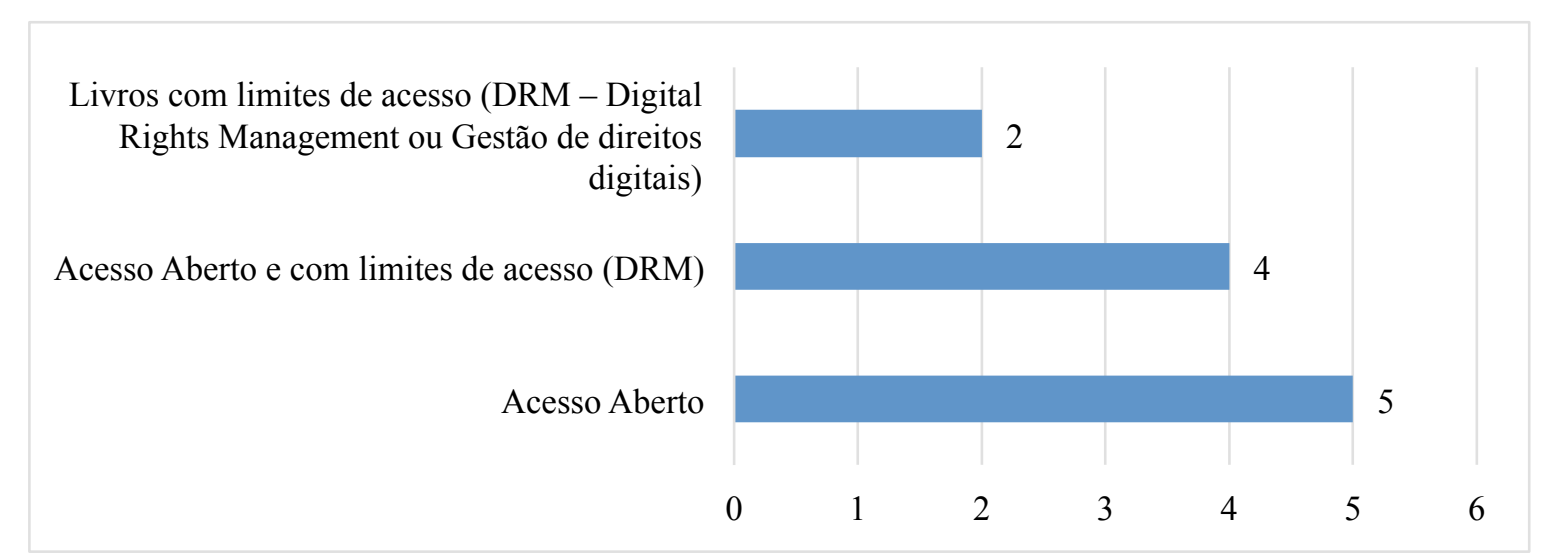

Fonte: Elaboração própria.

Foi constado que, das 12 bibliotecas que possuem livros eletrônicos em seus acervos, 10 possuem esses livros disponíveis em plataformas externas à biblioteca, assinadas, compradas ou apenas utilizadas. Dessas bases de dados externas, 7 disponibilizam livros eletrônicos de acesso aberto - dentre elas, 3 bibliotecas possuem a SciELO Livros, sendo que uma instituição disponibiliza o Projeto Gutenberg, uma o DOAB, uma a Biblioteca Digital Saraiva e outra o Domínio Público; ou seja, a plataforma externa de acesso aberto a livros eletrônicos mais utilizada pelas bibliotecas é a SciELO Livros. 
Gráfico 18: Base de dados que não são da biblioteca e disponibilizam livros eletrônicos de acesso aberto

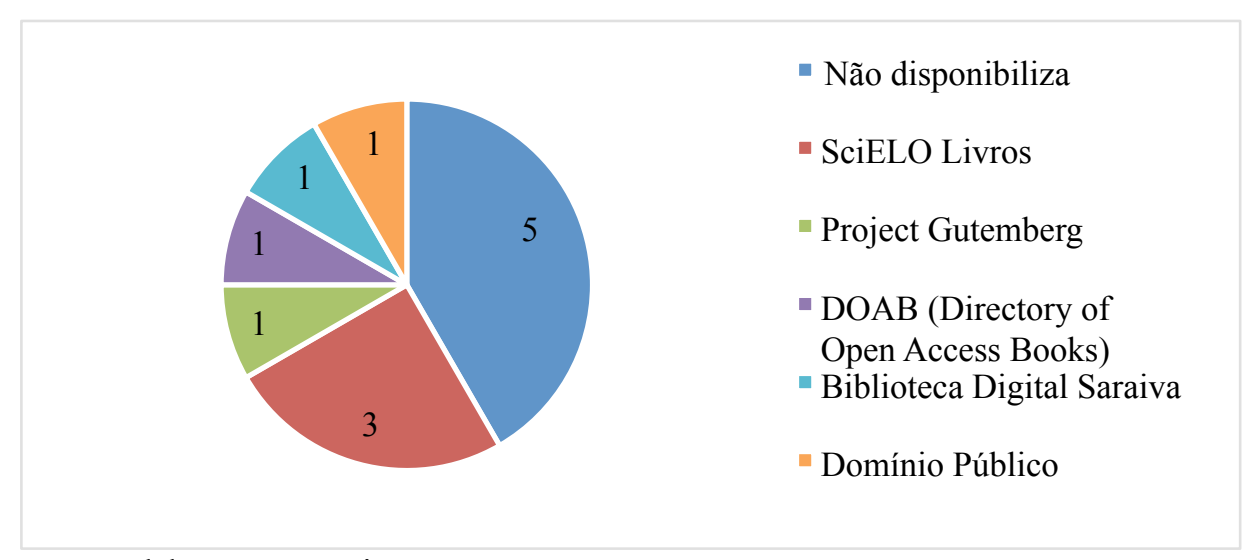

Fonte: Elaboração própria.

As 6 bibliotecas que responderam possuir bases de dados de livros eletrônicos de acesso restrito afirmaram que possuem 12 tipos diferentes dessas bases. Abaixo, no gráfico, é possível observar que a Biblioteca Virtual Acadêmica Pearson, a Minha Biblioteca, o ProQuest (ebray), o Portal Capes e a EBSCO foram as bases de dados que mais apareceram nas respostas. 
Gráfico 19: Base de dados que não são da biblioteca e disponibilizam livros eletrônicos de acesso restrito (DRM)

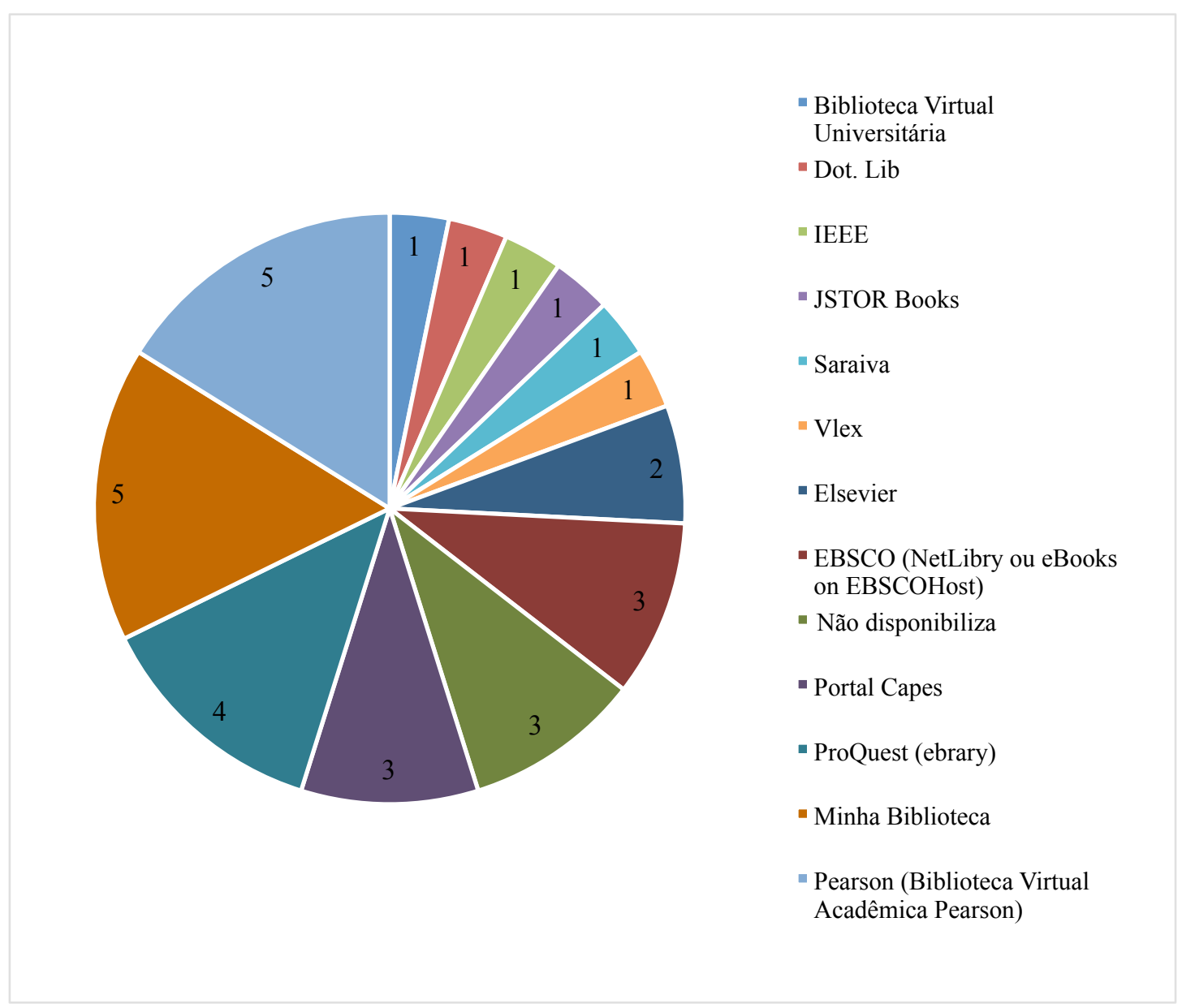

Fonte: Elaboração própria.

Outra questão levantada foi como é feito o empréstimo ou o acesso aos livros eletrônicos de acesso restrito. Algumas alternativas foram colocadas na questão e foi deixado um campo aberto, já que esse recurso ainda é muito controverso nas bases. A maioria respondeu que o acesso é feito apenas por meio da própria base proprietária e sem download. Apenas duas bibliotecas afirmaram que existe meios de se fazer download dos livros. 
Gráfico 20: Empréstimo dos livros eletrônicos de acesso restrito

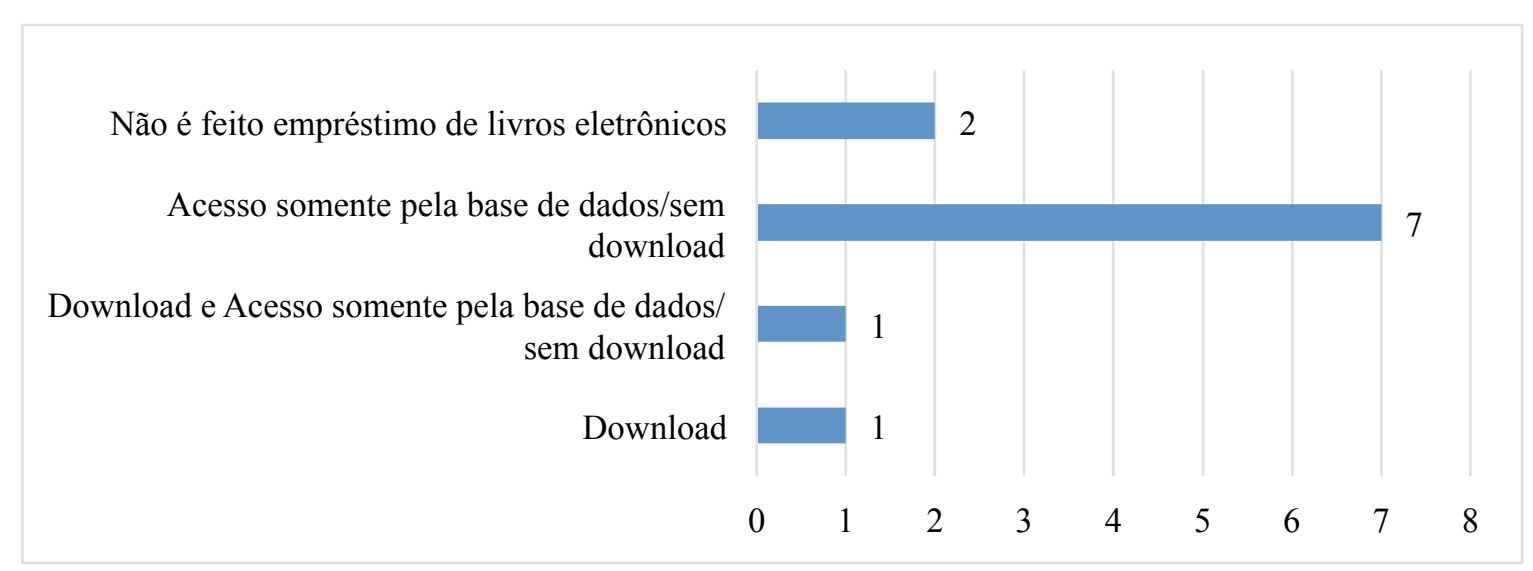

Fonte: Elaboração própria.

Quanto à tipologia dos livros eletrônicos disponíveis na biblioteca - tanto os de acesso restrito quanto os de acesso livre -, o tipo que prevaleceu foi o PDF, seguido do ePub e do HTML. Aparecem também o TXT e o DOC. Importa observar que o formato Mobi, muito difundido e conhecido no meio editorial por meio da Amazon e de seu Kindle, não foi mencionado.

\section{Gráfico 21: Tipologias e formatos de livros eletrônicos que a biblioteca disponibiliza aos usuários}

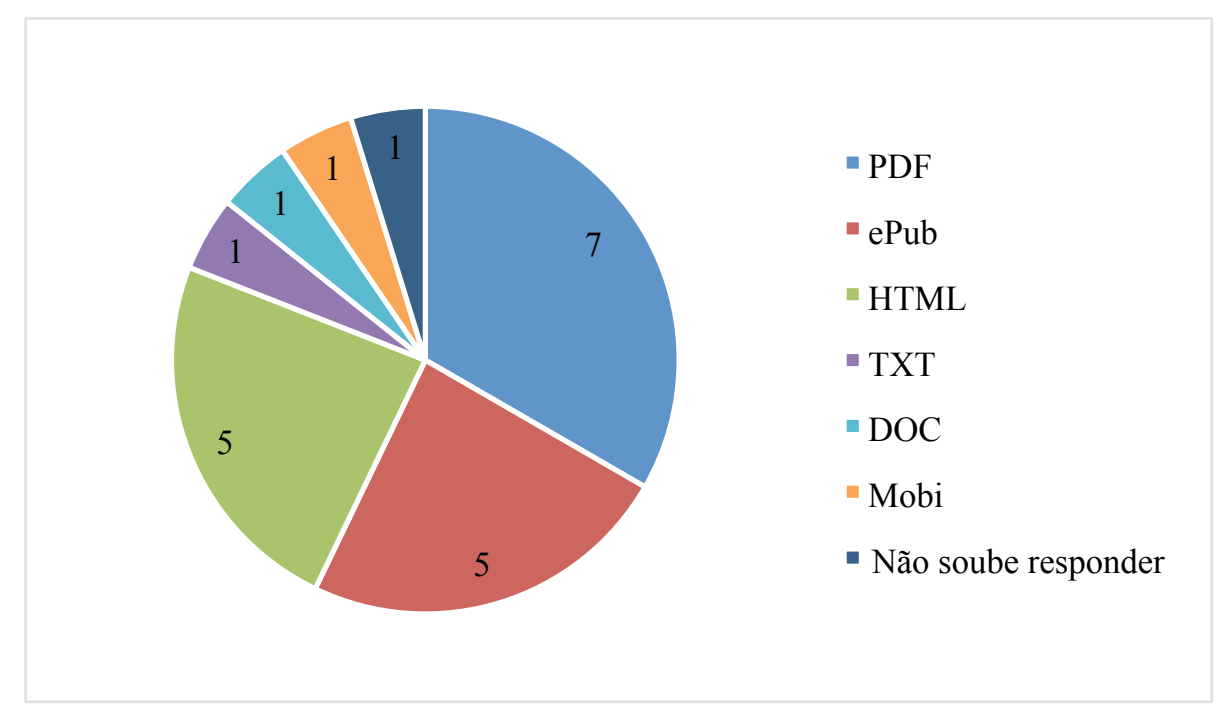

Fonte: Elaboração própria.

Questões muito citadas na revisão de literatura sobre livros eletrônicos em bibliotecas universitárias foi como esses livros são selecionados, as principais dificuldades e vantagens 
de seu uso, como são processados, se os usuários utilizam realmente esse material e a sua importância para o acervo da biblioteca. Tais questões foram também abordadas no questionário.

Sobre os critérios de seleção de livros eletrônicos, verificou-se que o principal indicador levado em conta pelas bibliotecas da amostra foi o da "forma de aquisição", seguido de "tipo de acesso" (aberto ou restrito) e do custo do material. Percebe-se, portanto, que os principais indicadores lembrados pelos bibliotecários ao responderem à pergunta são aqueles intimamente relacionados aos livros eletrônicos de acesso restrito, já que os de acesso aberto não têm o mesmo nível de preocupação com esses itens. Interessante observar que os indicadores de "formato do livro eletrônico" e "forma de preservação" foram os menos citados.

\section{Gráfico 22: Critérios de seleção de livros eletrônicos}

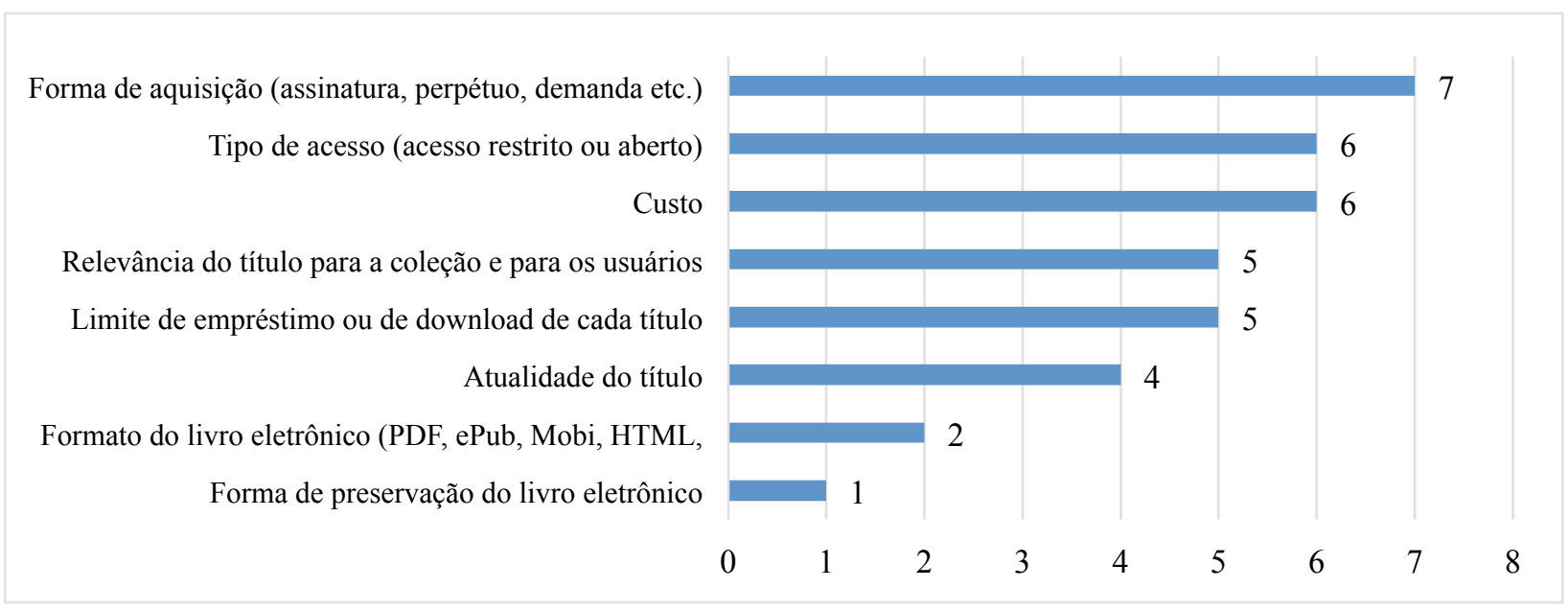

Fonte: Elaboração própria.

Sobre como os livros eletrônicos são processados na biblioteca, 8 afirmaram que eles não são catalogados, 2 disseram que eles são catalogados de uma forma específica para livros eletrônicos e 1 afirmou que eles já vêm catalogados da fonte; ou seja, há uma preocupação menor com o processamento técnico dessas obras, ou é possível que esse processamento já venha pronto da origem. Parece que não há a necessidade desse tipo de processamento para livros eletrônicos ou eles estão sendo negligenciados nesse quesito.

O orçamento específico para livros eletrônicos existe em 6 bibliotecas, enquanto 5 afirmaram não haver esse orçamento. Esse dado está bem equilibrado, o que demonstra a 
progressão da conscientização das instituições para a importância da aquisição e manutenção desse tipo de livro; contudo, ainda não é uma realidade para todas ou para a grande maioria.

A divulgação dos livros eletrônicos, dentre as bibliotecas da amostra, é feita principalmente pelo site da biblioteca, seguida do catálogo online, folhetos impressos, setor de referência e e-mails de divulgação. Portanto, existe uma preocupação latente na divulgação desse tipo de livro na grande maioria das bibliotecas: em apenas uma instituição a divulgação não é feita.

\section{Gráfico 23: Divulgação dos livros eletrônicos na biblioteca}

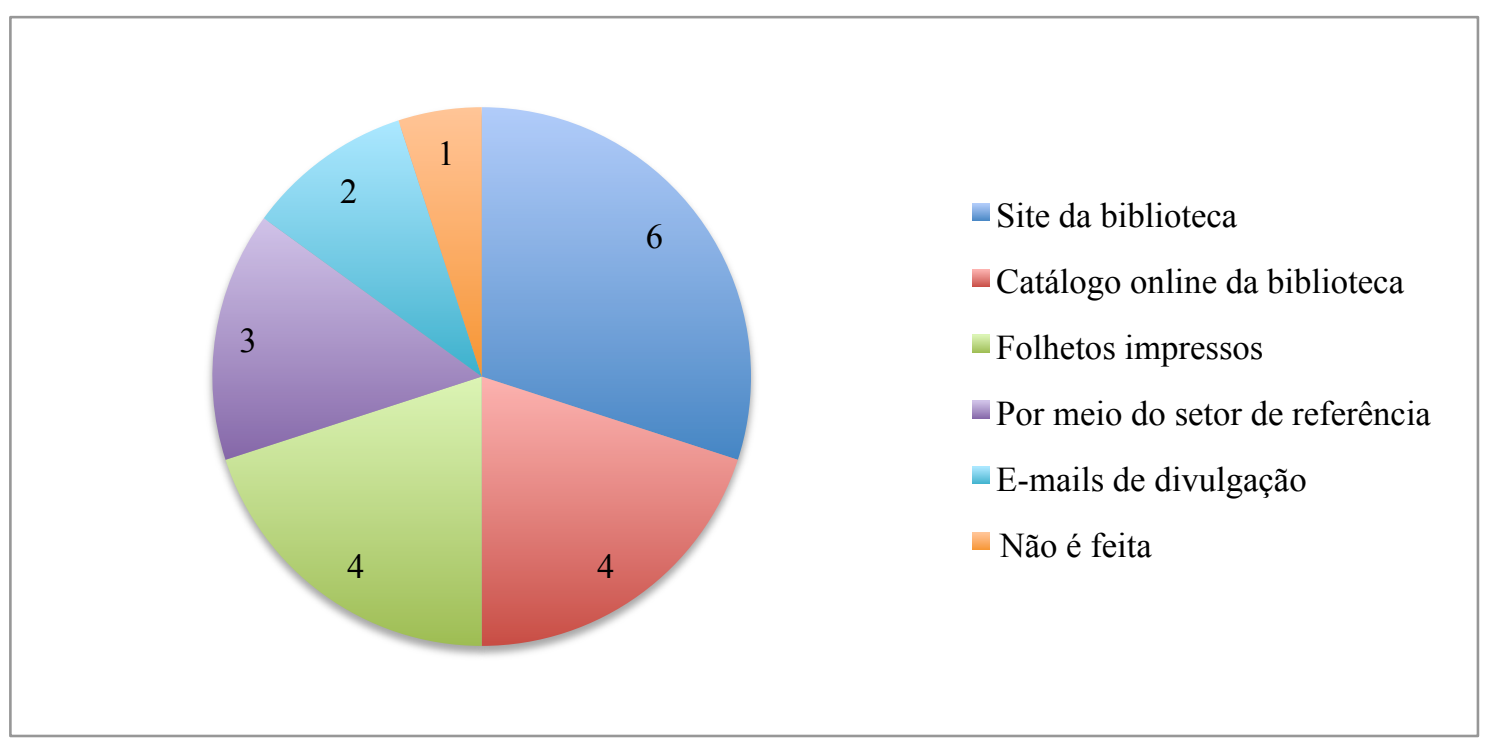

Fonte: Elaboração própria.

Sobre a existência de uma política de preservação digital para os livros eletrônicos nas bibliotecas a resposta foi de forma geral preocupante: nenhuma das respondentes possui tal política implantada. Contudo, verificou-se que a única universidade pública de Brasília respondeu ao questionário, e a biblioteca central dessa instituição participa de uma rede de preservação, a Rede Cariniana - promovida pelo Instituto Brasileiro de Informação em Ciência e Tecnologia (IBICT). Mas, diante do questionário coletado, nenhuma biblioteca afirmou haver projetos desse tipo. Tal dado pode ser corroborado pelo Gráfico 25 , onde o indicador "forma de preservação do livro eletrônico" só foi citado por uma biblioteca como um dos critérios de seleção de livros eletrônicos; ou seja, o quesito preservação de livros eletrônicos ainda não é algo com que as bibliotecas universitárias da amostra estão preocupadas. 
Seguindo para a questão da porcentagem de uso dos livros eletrônicos na biblioteca, foi verificado que não é a maioria dos usuários que utilizam os livros eletrônicos. Apenas uma biblioteca respondeu que mais de $70 \%$ de seus usuários utilizam livros eletrônicos, enquanto 3 afirmaram que o uso desses livros é feito por cerca de $20 \%$ a $50 \%$ dos usuários; outras 4 responderam que são de $10 \%$ a $20 \%$ dos usuários que os usam; e 3 dizem que até $10 \%$ dos usuários utilizam o acervo de livros eletrônicos.

Essas informações, aliadas a algumas outras, podem demonstrar alguns dados cruzados bastante interessantes. A biblioteca com o maior volume de acervo e um dos maiores atendimentos a usuários foi uma das que respondeu ter um uso de livros eletrônicos baixo: de $10 \%$ a $20 \%$. Contudo, a segunda maior biblioteca em número de acervo e também com um alto índice de atendimento aos usuários foi a única que respondeu que o uso de seus livros eletrônicos pelos usuários é de mais de 70\%. Contudo, esta última biblioteca possui um orçamento específico para compra de livros eletrônicos, enquanto aquela não - como visto mais adiante no Quadro 06. Ambas as bibliotecas fornecem livros eletrônicos de acesso aberto e de acesso restrito.

\section{Gráfico 24: Porcentagem de uso de livros eletrônicos existentes na biblioteca}

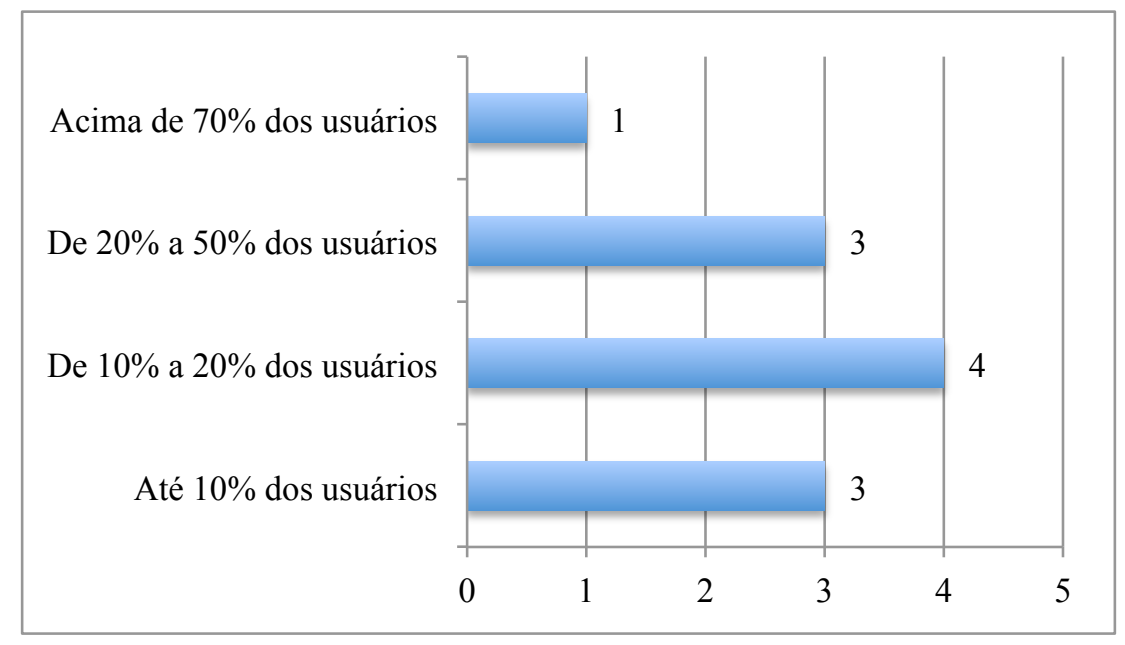

Fonte: Elaboração própria.

Seguindo as informações localizadas na revisão de literatura, em uma das questões foram listadas algumas das dificuldades mais citadas pelos autores sobre o uso de livros eletrônicos pelas bibliotecas universitárias, além de um campo aberto para inserção de outra dificuldade diferente das apresentadas na lista. A dificuldade mais encontrada para a formação do acervo de livros eletrônicos foi o orçamento da biblioteca, seguida da falta de 
uma política específica para esse tipo de livro e das formas de aquisição. Os limites de acesso e as formas de modelos de negócio disponíveis no mercado foram as dificuldades menos marcadas pelos respondentes. No entanto, aqui pode haver uma contradição entre as respostas, já que as formas de aquisição interferem diretamente no modelo de negócio de livros eletrônicos vendidos para as bibliotecas. Importante notar que apenas uma das dificuldades listadas não foi marcada: dificuldade na preservação. Como já apontamos, esse talvez seja um indicador ou atividade negligenciado pelas bibliotecas, e que precisa ser revisto com urgência, tendo em vista que a durabilidade dos livros impressos - como já se provou nos últimos séculos - pode ser bastante longa. Em contrapartida, não temos nem meio século de vida do surgimento dos livros eletrônicos, e como documentos informacionais valiosos - e às vezes caros - que são, é preciso que haja cuidados em sua preservação, ou seja, um programa de preservação digital dentro da biblioteca e regras de acesso juntos aos fornecedores coerentes com esses objetivos.

\section{Gráfico 25: Maiores dificuldades encontradas pela biblioteca na formação do acervo de livros eletrônicos}

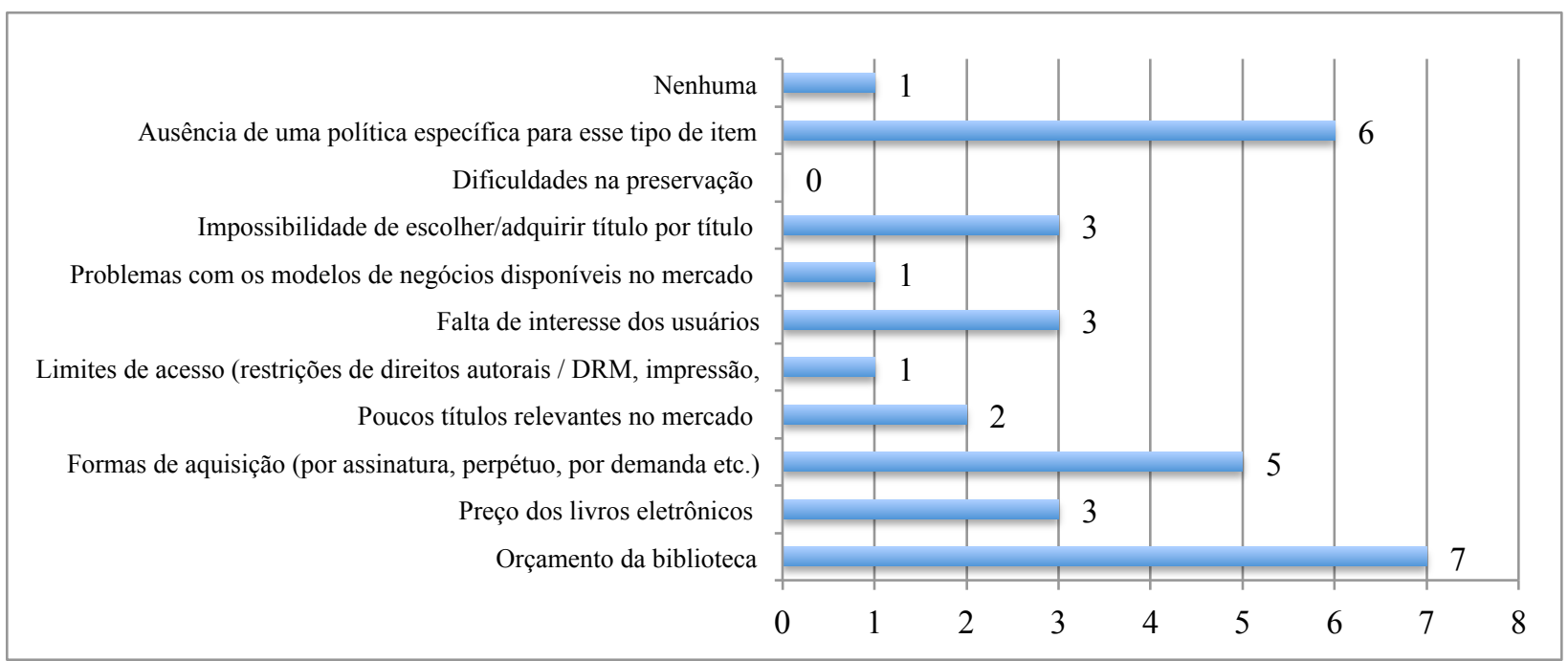

Fonte: Elaboração própria.

Após análise de todos os itens do questionário, mostrou-se importante observar alguns deles respondidos de forma comparativa. Um dos dados mais discrepantes da pesquisa foi o fato da biblioteca A ser a única, dentre as 14 bibliotecas da amostra, a apresentar um acesso de acima de $70 \%$ de seu acervo de livros eletrônicos por seus usuários, enquanto todas as demais terem um acesso inferior a 50\%. Um fato a ser observado é que a biblioteca A não é a maior biblioteca em tamanho de acervo físico, ou seja, o tamanho físico de uma biblioteca e 
de suas instalações não esteve relacionado diretamente com o acesso aos livros eletrônicos. Contudo, o número de usuários atendidos por mês demonstrou uma relação proporcional à porcentagem de uso de livros eletrônicos das bibliotecas. Quanto mais usuários, maior é a porcentagem de acesso - com exceção da biblioteca $\mathrm{B}$, que possui o maior acervo, mas não o maior uso de livros eletrônicos.

Outro dado importante é que todas as bibliotecas que responderam que possuem um orçamento específico para livros eletrônicos são também bibliotecas que possuem livros eletrônicos de acesso restrito em sua coleção; e, das que responderam que possuem apenas livros eletrônicos de acesso aberto, somente uma respondeu ter esse tipo de orçamento. Podese concluir que optar pela disponibilização de livros eletrônicos de acesso restrito gera uma necessidade financeira mais específica. Aqui é importante ressaltar que, para a área da Biblioteconomia, a aquisição de acervo não é apenas a compra de itens, mas também sua doação e permuta - pois que todas essas categorias demandam seleção prévia e recursos materiais, humanos e financeiros para sua manutenção. Portanto, o ideal seria que ambos os tipos de livros eletrônicos tivessem orçamentos para sua seleção e manutenção.

Sobre o tempo da coleção de livros eletrônicos, não se percebeu uma relação direta entre a antiguidade da disponibilização desses livros no acervo e a porcentagem de seu uso. As bibliotecas que responderam ter há mais de 6 anos livros eletrônicos em suas coleções variaram com o uso desses livros por seus usuários em acima de $70 \%$, de $20 \%$ a $50 \%$ e de $10 \%$ a $20 \%$, como foi o caso das bibliotecas A, B e G. Tais dados podem ser compreendidos devido à dinâmica desse tipo de livro, que leva em consideração não apenas sua qualidade, importância na literatura da área ou divulgação - como no caso dos livros físicos, mas também questões de tecnologia, de facilidade de acesso, de restrições de uso por direitos autorais, entre outros fatores.

Quadro 06: Dados sobre acesso e uso dos livros eletrônicos pelas bibliotecas universitárias

\begin{tabular}{|c|c|c|c|c|c|c|}
\hline Biblioteca & $\begin{array}{c}\text { Tamanho do } \\
\text { acervo (itens) }\end{array}$ & $\begin{array}{c}\text { Número de } \\
\text { usuários }\end{array}$ & Tipo de acesso & $\begin{array}{c}\text { Orçamento } \\
\text { específico } \\
\text { para } \boldsymbol{e} \text {-book }\end{array}$ & $\begin{array}{c}\text { Tempo da } \\
\text { coleção de } \boldsymbol{e} \text { - } \\
\text { books }\end{array}$ & $\begin{array}{c}\text { Uso de } \text {-book } \\
\text { pelos usuários }\end{array}$ \\
\hline A & 100.000 a 500.000 & Mais de 3.000 & $\begin{array}{c}\text { Acesso aberto Livros } \\
\text { com limites de acesso }\end{array}$ & Sim & Mais de 6 anos & Acima de $70 \%$ \\
\hline B & Mais de 500.000 & Mais de 3.000 & $\begin{array}{c}\text { Acesso aberto Livros } \\
\text { com limites de acesso }\end{array}$ & Não & Mais de 6 anos & De $10 \%$ a $20 \%$ \\
\hline C & 50.000 a 100.000 & 1.000 a 3.000 & $\begin{array}{c}\text { Livros com limites de } \\
\text { acesso }\end{array}$ & Sim & 2 a 4 anos & De $10 \%$ a $20 \%$ \\
\hline D & 1.000 a 50.000 & 1.000 a 3.000 & Acesso aberto & Não & 1 a 2 anos & De $10 \%$ a $20 \%$ \\
\hline E & 100.000 a 500.000 & 1.000 a 3.000 & -------- & Não & $\begin{array}{c}\text { Menos de } 01 \\
\text { ano }\end{array}$ & De $20 \%$ a $50 \%$ \\
\hline
\end{tabular}


Continuação

\begin{tabular}{|c|c|c|c|c|c|c|}
\hline $\mathbf{F}$ & 1.000 a 50.000 & 300 a 500 & Acesso aberto & Não & 1 a 2 anos & Até $10 \%$ \\
\hline $\mathbf{G}$ & 1.000 a 50.000 & 300 a 500 & $\begin{array}{l}\text { Acesso aberto Livros } \\
\text { com limites de acesso }\end{array}$ & Sim & Mais de 6 anos & De $20 \%$ a $50 \%$ \\
\hline $\mathbf{H}$ & $1.000 \mathrm{a} 50.000$ & 500 a 1.000 & --------- & - & ------- & -------- \\
\hline I & 50.000 a 100.000 & 1.000 a 3.000 & Acesso aberto & --------- & 2 a 4 anos & --------- \\
\hline $\mathbf{J}$ & 100.000 a 500.000 & Mais de 3.000 & $\begin{array}{l}\text { Acesso aberto Livros } \\
\text { com limites de acesso }\end{array}$ & Sim & 2 a 4 anos & De $20 \%$ a $50 \%$ \\
\hline $\mathbf{K}$ & 50.000 a 100.000 & 500 a 1.000 & Acesso aberto & Não & 2 a 4 anos & Até $10 \%$ \\
\hline $\mathbf{L}$ & 1.000 a 50.000 & $1.000 \mathrm{a} 3.000$ & ----------- & ----------- & ---------- & ----------- \\
\hline $\mathbf{M}$ & 1.000 a 50.000 & 300 a 500 & Acesso aberto & Sim & $\begin{array}{l}\text { Menos de } 01 \\
\text { ano }\end{array}$ & De $10 \%$ a $20 \%$ \\
\hline $\mathbf{N}$ & 50.000 a 100.000 & 300 a 500 & $\begin{array}{l}\text { Livros com limites de } \\
\text { acesso }\end{array}$ & Sim & $\begin{array}{c}\text { Menos de } 01 \\
\text { ano }\end{array}$ & Até $10 \%$ \\
\hline
\end{tabular}

Fonte: Elaboração própria.

A última parte do questionário buscou obter uma opinião do bibliotecário sobre a importância dos livros eletrônicos nas bibliotecas universitárias, após todo o exercício de resposta das 41 questões e levando em consideração sua experiência como um profissional da informação desse tipo de biblioteca.

Ao serem questionados sobre a relevância dos livros eletrônicos para a formação dos usuários da biblioteca, absolutamente todos os respondentes afirmaram que sim, que esse tipo de livro é importante para seus usuários. A pergunta pode parecer óbvia, mas tendo em vista que esse tipo de livro não é algo consolidado dentre as fontes de informação das bibliotecas mundiais, que o mercado com seus modelos de negócio ainda não se adaptaram a todas as demandas das bibliotecas ainda e que o custo, o acesso e a preservação dos livros eletrônicos ainda são um grande entrave à sua utilização nessas unidades de informação, mostrou-se positiva a expectativa desses bibliotecários com relação a esse tipo de material informacional.

A última pergunta do questionário foi aberta e inquiria sobre a importância do livro eletrônico para a biblioteca universitária. As respostas foram bastante interessantes, e muitas delas corroboraram as vantagens listadas na revisão de literatura do uso dos livros eletrônicos pelas bibliotecas universitárias. Abaixo, segue um quadro com as respostas obtidas; os grifos foram feitos no texto de forma a exaltar as principais vantagens e nível de importância do uso de livros eletrônicos pelas bibliotecas universitárias, na visão de seus bibliotecários. 
Quadro 07: Qual a importância dos livros eletrônicos para a biblioteca universitária

Na sua opinião, qual é a importância dos livros eletrônicos em uma biblioteca universitária?

\begin{tabular}{|c|c|}
\hline Biblioteca & Resposta \\
\hline $\mathbf{A}$ & $\begin{array}{l}\text { O acesso a livros eletrônicos em uma biblioteca universitária tem a importância de facilitar o } \\
\text { acesso e uso da informação por parte de seus usuários. Visto que traz praticidade de acesso } \\
\text { por meio de dispositivos móveis, permite que a obra seja acessada a qualquer momento, o } \\
\text { usuário não tem que se preocupar com uma cota máxima de livros que podem ser } \\
\text { emprestados, nem se preocupar com renovações e além de não precisar se deslocar } \\
\text { fisicamente até a biblioteca. }\end{array}$ \\
\hline B & $\begin{array}{l}\text { Eles são importantes na formação e desenvolvimento do acervo. Infelizmente o Ministério } \\
\text { da Educação ainda determina critérios de avaliação do acervo muito distintos em relação ao } \\
\text { material impresso, o que dificulta a cultura de utilização e disseminação dos conteúdos } \\
\text { digitais. }\end{array}$ \\
\hline $\mathbf{C}$ & $\begin{array}{l}\text { Facilitar o acesso à informação por parte dos usuários, além de proporcionar o contato deles } \\
\text { com os mais variados suportes em que a informação pode estar disponibilizada, } \\
\text { educando-os quanto à melhor maneira de consultar e preservar o conhecimento de acordo com } \\
\text { suas necessidades específicas. }\end{array}$ \\
\hline D & --------- \\
\hline $\mathbf{E}$ & $\begin{array}{l}\text { É importante para facilitar o acesso dos usuários aos livros e devido ao contexto tecnológico } \\
\text { vivido por nós. Acredito que para essa nova geração de usuários a utilização de livros } \\
\text { eletrônicos com a facilidade de acessá-los em qualquer lugar e em qualquer hora e não se } \\
\text { prender, necessariamente, dentro de uma biblioteca (não que isso seja ruim, mas devido à } \\
\text { rotina corrida da maioria dos estudantes e também pelo perfil high tech) se faz imprescindivel } \\
\text { para que concluam suas atividades acadêmicas. Assim como suporte para os cursos EAD. }\end{array}$ \\
\hline $\mathbf{F}$ & É possibilitar o acesso informacional de forma democrática e rápida. \\
\hline G & $\begin{array}{l}\text { A relevância dos livros eletrônicos está na disponibilização do conteúdo que permite } \\
\text { ultrapassar o espaço físico da biblioteca, não tem extravio de material, a biblioteca ganha } \\
\text { no espaço físico etc. }\end{array}$ \\
\hline $\mathbf{H}$ & ----------- \\
\hline $\mathbf{I}$ & ------------ \\
\hline $\mathbf{J}$ & $\begin{array}{l}\text { Os livros eletrônicos são importantes para complementar o acervo físico oferecido pela } \\
\text { biblioteca. }\end{array}$ \\
\hline $\mathbf{K}$ & $\begin{array}{l}\text { A biblioteca tem que acompanhar as inovações tecnológicas, pois os alunos utilizam os livros } \\
\text { eletrônicos como mais um meio de estudo. Este mesmo se torna relevante, pois vários } \\
\text { usuários podem ler o mesmo livro ao mesmo tempo, sem ter a necessidade de se deslocar. }\end{array}$ \\
\hline $\mathbf{L}$ & ----------- \\
\hline $\mathbf{M}$ & $\begin{array}{l}\text { A importância do livro eletrônico é a possibilidade de levar informação de maneira ágil, } \\
\text { com autonomia e podendo atender maior quantidade de usuários. }\end{array}$ \\
\hline $\mathbf{N}$ & ----------- \\
\hline
\end{tabular}

Fonte: Elaboração própria.

Para se ter uma visão mais precisa das respostas, foram categorizadas no Quadro 07 as principais vantagens que os bibliotecários apontaram, de acordo com uma categoria mais ampla. A partir desse exercício, é possível observar que, para os bibliotecários respondentes da amostra, as principais vantagens do uso do livro eletrônico em bibliotecas universitárias para os usuários são as questões das ferramentas tecnológicas, possibilidades de 
acesso/locomoção e as questões técnicas e processuais da biblioteca. Portanto, é possível perceber que os bibliotecários levam em consideração também as facilidades que esse tipo de livro traz para as bibliotecas antes e durante o acesso aos livros. Caso fosse feito um estudo de uso dos livros eletrônicos pelos usuários, provavelmente eles não responderiam que uma das vantagens seria o ganho de espaço físico na biblioteca ou questões de diminuição de extravio de material. Mas os bibliotecários citaram várias vantagens exclusivas para os usuários também, como a questão de não ser necessário deslocamento físico à biblioteca, a disponibilidade de um mesmo livro eletrônico para vários usuários ou um acesso mais rápido e autônomo.

\section{Quadro 08: Vantagens do uso do livro eletrônico para os usuários de bibliotecas universitárias na visão dos bibliotecários}

\begin{tabular}{|c|c|}
\hline Vantagens gerais & Vantagens citadas pelos bibliotecários \\
\hline $\begin{array}{l}\text { Questões técnicas e processuais } \\
\text { da biblioteca }\end{array}$ & $\begin{array}{l}\text { - Formação e desenvolvimento do acervo; } \\
\text { - Ganha no espaço físico; } \\
\text { - Ler o mesmo livro ao mesmo tempo; } \\
\text { - Maior quantidade de usuários. } \\
\end{array}$ \\
\hline $\begin{array}{l}\text { Possibilidades de } \\
\text { acesso/locomoção }\end{array}$ & $\begin{array}{l}\text { - Facilitar o acesso e uso da informação; } \\
\text { - Traz praticidade de acesso; } \\
\text { - Necessidade de se deslocar; } \\
\text { - Levar informação de maneira ágil com autonomia. }\end{array}$ \\
\hline Ferramentas tecnológicas & $\begin{array}{l}\text { - Contato deles com os mais variados suportes em que a informação } \\
\text { pode estar disponibilizada. }\end{array}$ \\
\hline Acessibilidade/disponibilidade & $\begin{array}{l}\text { - Traz praticidade de acesso; } \\
\text { - Acesso informacional de forma democrática e rápida; } \\
\text { - Livros eletrônicos como mais um meio de estudo; } \\
\text { - Ler o mesmo livro ao mesmo tempo; } \\
\text { - Maior quantidade de usuários. }\end{array}$ \\
\hline Conteúdos agregadores & • $\quad$ Disponibilização do conteúdo. \\
\hline Dificuldades para roubos e avarias & - Não tem extravio de material. \\
\hline Vantagens para a Faculdade & $\begin{array}{l}\text { - Concluam suas atividades acadêmicas; } \\
\text { - Suporte para os cursos EAD; } \\
\text { - Complementar o acervo físico oferecido pela biblioteca. }\end{array}$ \\
\hline
\end{tabular}

Fonte: Elaboração própria. 


\section{CONSIDERAÇÕES FINAIS}

A história do livro impresso talvez nunca esteja concluída. Enquanto houver humanos que o tenham conhecido e utilizado, ele será uma tecnologia lembrada. Desse objeto vários outros derivaram, em gênero, formato e conceito. O livro eletrônico não poderia ser diferente - até mesmo no nome, o qual faz referência direta a seu predecessor. É indubitável a importância do livro impresso para o progresso científico e cultural do ser humano, muito se pode conjecturar sobre seu desaparecimento ou substituição, mas nada de real ainda existe nesse campo premonitório. Contudo, pode o livro eletrônico tomar para si essa responsabilidade? Essa pesquisa mostra que é cedo para certas afirmações. Mas sim, ele está encontrando espaço no mundo acadêmico e científico. Todas as bibliotecas universitárias pesquisadas nesse estudo afirmaram ter livros eletrônicos em suas coleções, todos os seus bibliotecários exaltaram a importância desse livro para seus usuários e mostraram certa familiaridade com ele.

O que se encontra hoje é um conceito acadêmico não muito consolidado sobre livro eletrônico, mas categorias e características definidoras desse livro muito congruentes entre si - tanto na literatura da área quanto na visão dos bibliotecários. Diferente foi o encontrado na legislação pátria: o Congresso Nacional ainda não decidiu o que vem a ser o livro eletrônico ou digital, como ele o normatiza. Não se tem muito clara a diferenciação de conteúdo e suporte do livro eletrônico, e aqui, talvez, seja a grande diferença desse novo objeto informacional: ele não existe sozinho, como um objeto todo. Ele só é possível por meio de uma tecnologia que dependa de outras e mais outras: da linguagem binária, que depende do software para leitura, que depende do hardware para rodar, que depende da energia elétrica para funcionar - sem contar fatores paralelos como internet, conhecimento de programação, direitos autorais em todos os níveis de acesso, entre outros. Tendo em conta que o livro impresso também é uma tecnologia, ele o é de forma atemporal. Acaso um cidadão do século XVI viajasse no tempo e se deparasse com um livro eletrônico, nada entenderia - o mesmo não aconteceria caso ele tivesse acesso a um livro impresso, lançamento de qualquer livraria do mundo atual. Ainda não somos totalmente tecnológicos e nativos digitais; é possível que esse cenário de estranhamento mude, mas a realidade atual ainda não permite tal conclusão.

Diante disso, foi difícil traçar um perfil predominante entre as bibliotecas universitárias participantes da pesquisa. Absolutamente todas possuem livros eletrônicos em seus acervos - sejam eles de acesso restrito ou não. Seus aparatos tecnológicos e técnicos variam de acordo com o tamanho de seu acervo e do número de usuários atendidos por mês. 
Algo que as uniu foi a dificuldade ainda sentida com relação à seleção e o acervo de livros eletrônicos que possuem. Por se tratar de objeto informacional relativamente recente e média receptividade pelo público universitário, políticas específicas e facilidades mercadológicas ainda são escassas - no caso da política, de fato, nenhuma biblioteca afirmou a possuir.

No mapa de pesquisa abaixo, há um breve resumo do caminho conceitual e científico que delineou esse estudo. Os quatro objetivos específicos foram alcançados - com a ressalva da amostra não cobrir com grande satisfatoriedade o número de IES do Distrito Federal. Contudo, todas as universidades, a maioria dos centros universitários, todas as faculdades públicas e as faculdades de maior renome e conhecimento dentro do DF foram cobertas pela pesquisa, e responderam ao questionário. O que pode demonstrar, como um destaque do cenário distrital, um retrato de como as bibliotecas universitárias do DF vêm gerindo e utilizando os livros eletrônicos em seus acervos, o que, consequentemente, contribuiu para o alcance do objetivo geral de pesquisa. 
Quadro 09: Mapa de pesquisa

\begin{tabular}{|c|c|c|c|c|c|}
\hline $\begin{array}{c}\text { Objetivo } \\
\text { Geral }\end{array}$ & \multicolumn{5}{|c|}{ Analisar como é feita a gestão e o uso de livros eletrônicos nas coleções das bibliotecas universitárias do DF } \\
\hline \multirow[b]{5}{*}{$\begin{array}{l}\text { Objetivo } \\
\text { Específico }\end{array}$} & $\begin{array}{l}\text { Objetivo } \\
\text { Específico }\end{array}$ & Variável & $\begin{array}{c}\text { Participantes/ } \\
\text { material }\end{array}$ & Método & Resultado \\
\hline & $\begin{array}{l}\text { Identificar os } \\
\text { principais } \\
\text { conceitos de livro } \\
\text { impresso e livro } \\
\text { eletrônico na } \\
\text { literatura e traçar } \\
\text { um comparativo } \\
\text { entre eles. }\end{array}$ & $\begin{array}{l}\text { Conceitos e } \\
\text { histórico de } \\
\text { livros e livros } \\
\text { eletrônicos na } \\
\text { literatura. }\end{array}$ & $\begin{array}{l}\text { Literatura da } \\
\text { área }\end{array}$ & $\begin{array}{l}\text { Revisão de } \\
\text { literatura }\end{array}$ & $\begin{array}{l}\text { O livro impresso possui um conceito } \\
\text { e histórico bem delineados e } \\
\text { definidos. O conceito de livro } \\
\text { eletrônico está em processo de } \\
\text { formação científica e legal, a } \\
\text { literatura acadêmica sobre ele está } \\
\text { em construção e sua relação com o } \\
\text { conceito de livro impresso é muito } \\
\text { grande ainda. }\end{array}$ \\
\hline & $\begin{array}{l}\text { Mapear quais } \\
\text { bibliotecas } \\
\text { universitárias do } \\
\text { DF possuem } \\
\text { coleções de livros } \\
\text { eletrônicos. }\end{array}$ & $\begin{array}{l}\text { Mapeamento } \\
\text { de bibliotecas } \\
\text { universitárias } \\
\text { no DF que } \\
\text { possuem } \\
\text { livros } \\
\text { eletrônicos. }\end{array}$ & $\begin{array}{l}\text { Site MEC e } \\
\text { bibliotecas/ } \\
\text { bibliotecários }\end{array}$ & $\begin{array}{l}\text { Questionário: } \\
\text { questões } \\
\text { abertas e } \\
\text { fechadas }\end{array}$ & $\begin{array}{l}\text { Das } 41 \text { bibliotecas de IES } \\
\text { localizadas, } 14 \text { responderam ter em } \\
\text { suas coleções livros eletrônicos. } \\
\text { Todas as bibliotecas de } \\
\text { universidades, instituto de } \\
\text { tecnologia, IES públicas do DF e a } \\
\text { maioria dos centros universitários } \\
\text { responderam ao questionário. }\end{array}$ \\
\hline & $\begin{array}{l}\text { Identificar como } \\
\text { os bibliotecários } \\
\text { das bibliotecas } \\
\text { universitárias do } \\
\text { DF conceituam e } \\
\text { definem os livros } \\
\text { eletrônicos. }\end{array}$ & $\begin{array}{l}\text { Conceitos e } \\
\text { definição de } \\
\text { livros } \\
\text { eletrônicos por } \\
\text { bibliotecários }\end{array}$ & Bibliotecários & $\begin{array}{l}\text { Questionário: } \\
\text { questões } \\
\text { abertas e } \\
\text { fechadas }\end{array}$ & $\begin{array}{l}\text { Conceituam como livros em } \\
\text { plataformas digitais e eletrônicas, } \\
\text { com funções e formato semelhantes } \\
\text { às do livro impresso, que podem ser } \\
\text { lidos em qualquer plataforma digital } \\
\text { e que fornecem novas } \\
\text { possibilidades tecnológicas. }\end{array}$ \\
\hline & $\begin{array}{l}\text { Apontar como os } \\
\text { livros eletrônicos } \\
\text { estão sendo } \\
\text { geridos e } \\
\text { utilizados pelas } \\
\text { bibliotecas } \\
\text { universitárias do } \\
\text { DF. }\end{array}$ & $\begin{array}{l}\text { Gestão e uso } \\
\text { dos livros } \\
\text { eletrônicos em } \\
\text { bibliotecas } \\
\text { universitárias }\end{array}$ & $\begin{array}{l}\text { Bibliotecas/ } \\
\text { bibliotecários }\end{array}$ & $\begin{array}{l}\text { Questionário: } \\
\text { questões } \\
\text { abertas e } \\
\text { fechadas }\end{array}$ & $\begin{array}{l}\text { Apesar do uso de livros eletrônicos } \\
\text { não ser unanimidade entre os } \\
\text { usuários, as bibliotecas } \\
\text { universitárias possuem coleções de } \\
\text { livros eletrônicos de acesso aberto e } \\
\text { restrito em seus acervos, } \\
\text { disponibilizando bases de dados de } \\
\text { acesso pago e livre. Há dificuldades } \\
\text { para a seleção dos livros } \\
\text { eletrônicos, como as suas formas de } \\
\text { aquisição, seu tipo de acesso e seu } \\
\text { custo. As maiores dificuldades } \\
\text { encontradas na coleção foram a } \\
\text { ausência de uma política específica } \\
\text { e o orçamento da biblioteca para } \\
\text { esse tipo de material. Nenhuma } \\
\text { possui preocupações reais com a } \\
\text { preservação dos livros eletrônicos } \\
\text { disponibilizados. O perfil das } \\
\text { bibliotecas pesquisadas foi } \\
\text { predominante de médio a grande } \\
\text { porte, com um número alto de } \\
\text { atendimento mensal aos usuários, } \\
\text { boa disponibilização de bases de } \\
\text { dados e equipamentos tecnológicos } \\
\text { de consulta aos usuários. São } \\
\text { preponderantemente especializadas } \\
\text { nas áreas de Ciências Sociais } \\
\text { Aplicadas, Línguas, Letras e Artes, } \\
\text { Ciências da Saúde e } \\
\text { Multidisciplinares. }\end{array}$ \\
\hline
\end{tabular}

Fonte: Elaboração própria.

Portanto, configura-se a dicotomia entre a necessidade de ter o livro eletrônico e falta de empenho ou oportunidade de entendê-lo dentro dos acervos das bibliotecas universitárias. 
Nesse momento, talvez, esteja se configurando o nascimento de uma nova prática. Algumas bibliotecas já utilizam bases proprietárias internacionais de livros eletrônicos de acesso restrito, e a grande maioria possui ou induz o acesso a bases nacionais e internacionais que disponibilizam livros eletrônicos de acesso aberto. Contudo, esses livros ainda não são catalogados ou tratados tecnicamente como os demais livros impressos ou itens do acervo. Entretanto, livros eletrônicos podem ser comparados, em certa medida, com os periódicos científicos online, que também não são catalogados pela instituição, quando já inclusos na fonte em base de dados externas à biblioteca. Talvez esse seja o caminho que o livro eletrônico esteja tomando em relação a seus processos técnicos. Mas, então, seria necessário tratá-los da mesma forma e proeminência que os periódicos: acesso a bases importantes nacionais e internacionais, programas de treinamento ao usuário com relação ao uso dessas bases, continuidade de assinaturas, orçamentos e políticas específicas - já que, apesar de poderem ser objetos informacionais parecidos, por se tratar de informação digital necessária ao estudante, não têm as mesmas características conceituais, acadêmicas e estruturais.

Como o tema é muito recente e possui um campo vasto de possibilidades acadêmicas, sugere-se como futuros estudos, no que concerne aos livros eletrônicos: pesquisas sobre o uso específico do livro eletrônico de acesso restrito nas bibliotecas universitárias; a relação entre políticas de seleção, aquisição e procedimentos adotados para periódicos acadêmicos de acesso online e o livro eletrônico; a forma como o MEC lida ou deveria lidar com os livros eletrônicos dentro da formação legal do acervo das bibliotecas universitárias no Brasil; formas atuais e possíveis de preservação do livro eletrônico acadêmico; mercado de negócio do livro eletrônico para bibliotecas universitárias; como está sendo feito o uso do livro eletrônico pelos estudantes universitários do DF; possíveis diferenças de aprendizagem entre o estudante que usa o livro impresso e aquele que usa o eletrônico; quantidade e qualidade das indicações de livros eletrônicos nas bibliografias dos cursos universitários; como o livro eletrônico pode modificar a realidade do estudante de baixa renda; o espaço que o livro eletrônico possui na indústria editorial acadêmica; as definições legais de livros eletrônicos ao redor do mundo; dentre tantas outras possibilidades de estudo que enriqueceriam a literatura da área e trariam benefícios no delineamento da pesquisa do livro eletrônico.

Uma das limitações encontradas na pesquisa foi uma literatura não muito escassa, mas não definitiva sobre o tema livros eletrônicos, proporcionando muitas interpretações sobre a definição, nomenclatura e uso desses livros. Contudo, ela se mostrou muito interessante por mostrar vários caminhos possíveis a seguir nos estudos sobre o tema, assim como certo empenho por alguns autores na tentativa da consolidação dos estudos na área. Outra limitação 
foi a dificuldade em contatar as bibliotecas das IES do Distrito Federal. Várias delas não possuíam informações de contato em seus sites, ou não possuíam biblioteca formada ou profissionais disponíveis para responder ao questionário.

Cunha e Cavalcanti (2010), em seu dicionário, definem o termo incunábulo como o livro impresso nos primeiros 50 anos do surgimento da imprensa - de 1450 a 1500 . Esses livros são verdadeiros tesouros nacionais e particulares, para quem os tem. São a prova do nascimento de algo assustadoramente forte e modificador, que mudaria definitivamente o curso da história humana. Não são apenas objetos dotados de informações inscritas, são objetos que cunham em sua própria existência um passado fecundo e um futuro cheio de possibilidades. Será que a história permitirá ao ser humano presenciar outro momento como esse? É possível pensar no berço, ou no incunabulum, de um novo momento histórico a partir de um novo conceito de livro? Talvez seja cedo para afirmar que os primeiros livros eletrônicos do início do século XXI sejam os incunábulos de um novo objeto cultural. Mas não se pode furtar ao ser humano a possibilidade e o prazer de pertencer a um momento como esse novamente, quando é possível viver em dias tão interessantes, como aqueles em que o livro impresso surgiu no Ocidente, trazendo toda sua potencialidade e religação ao mundo que sempre esteve ao redor, apenas esperando que se escreva sobre ele. 


\section{REFERÊNCIAS}

ALTER, Alexandra. The plot twist: e-book sales slip, and print is far from dead. The New York Times, sept. 2015. Disponível em:

$<$ http://www.nytimes.com/2015/09/23/business/media/the-plot-twist-e-book-sales-slip-andprint-is-far-from-dead.html?_r=0>. Acesso em: $10 \mathrm{dez} .2015$.

ALVARENGA, L. A teoria do conceito revisitada em conexão com ontologias e metadados no contexto das bibliotecas tradicionais e digitais. DataGramaZero, Rio de Janeiro, v. 2, n. 6, dez. 2001. Disponível em: <http://www.dgz.org.br/dez01/F_I_art.htm>. Acesso em: 10 nov. 2015 .

ARAÚJO, Emanuel. A construção do livro: princípios da técnica de editoração. Rio de Janeiro: Nova Fronteira; Brasília: INL - Instituto Nacional do Livro, 1986.

ARMSTRONG, Chris. Books in a virtual world: the evolution of the e-book and its lexicon. Journal of Librarianship and Information Sciense, v. 40, n. 3, p. 193-206, set. 2008.

Disponível em: <http://lis.sagepub.com/content/40/3/193.refs >. Acesso em: 20 maio 2014.

ASSOCIAÇÃO BRASILEIRA DE NORMAS TÉCNICAS. NBR 6029: informação e documentação: livros e folhetos: apresentação. Rio de Janeiro, 2002.

BAPTISTA, Dulce M. Internet e livro: uma falsa dicotomia. RICI: Revista Ibero-americana de Ciência da Informação, v. 4, n. 2, p. 40-52, ago./dez. 2011.

BELKIN, N. J. Information concepts for information science. Journal of Documentation, v. 34, n. 1, p. 55-85, mar. 1978.

BESEN, Stanley M.; KIRBY, Sheila N. E-books and libraries: an economic perspective. Chicago: American Library Association (ALA), 2012. Disponível em:

$<$ http://www .ala.org/transforminglibraries/sites/ala.org.transforminglibraries/files/content/fina 1\%20economic\%20report\%20sept2012.pdf>. Acesso em: 05 dez. 2015.

BLUESTONE, Marisa. AAP statshot: publisher net revenue from book sales decline $4.1 \%$ in first half of 2015. AAP Association of American Publishers, oct. 2015. Disponível em: $<$ http://publishers.org/news/aap-statshot-publisher-net-revenue-book-sales-declines-41-firsthalf-2015>. Acesso em: 03 fev. 2016.

BODÊ, E. C. Preservação de documentos digitais: o papel dos formatos de arquivo. 2008. 153 f. Dissertação (Mestrado em Ciência da Informação). Faculdade de Economia, Administração, Contabilidade, Ciência da Informação e Documentação, Universidade de Brasília, Brasília, 2008. Disponível em: <http://repositorio.unb.br/handle/10482/2034>. Acesso em: 10 jun. 2015.

BORGMAN, C. L. From Gutenberg to the global information infrastructure: access to information in the networked world. Cambridge, MA: MIT Press, 2000.

BORKO, Harold. Information science: what is it? American Documentation, v. 19, n. 1, 1968. BRANDÃO, Oscar C.; DUQUE, Cláudio G. Comunicação científica contemporânea e de 
vanguarda. In: DUQUE, Cláudio G. (Org.). Ciência da informação estudos e práticas. Brasília: Centro Editorial; Thesaurus, 2011.

BRASIL. Câmara dos Deputados. Projeto de Lei PL 4534/2012. Altera a Lei no 10.753, de 30 de outubro de 2003, que institui a Política Nacional do Livro, para atualizar a definição de livro e para alterar a lista de equiparados a livro. 2012. Disponível em:

$<$ http://www.camara.gov.br/proposicoes Web/fichadetramitacao?idProposicao=556891 $>$. Acesso em: 02 fev. 2015.

BRASIL. Decreto $n^{\circ} 5.773$, de 09 de maio de 2006. Dispõe sobre o exercício das funções de regulação, supervisão e avaliação de instituições de educação superior e cursos superiores de graduação e sequenciais no sistema federal de ensino. 2006. Disponível em:

$<$ http://www.planalto.gov.br/ccivil_03/_ato2004-2006/2006/decreto/d5773.htm>. Acesso em: 01 fev. 2016.

BRASIL. Lei ${ }^{\circ} 10.753$, de 30 de outubro de 2003. Institui a Política Nacional do Livro. 2003. Disponível em: < http://www.planalto.gov.br/ccivil_03/leis/2003/L10.753.htm>. Acesso em: 10 abr. 2015.

BRASIL. Lei no 10.861, de 14 de abril de 2004. Institui o Sistema Nacional de Avaliação da Educação Superior - SIANES e dá outras providências. 2004. Disponível em:

$<$ http://www.planalto.gov.br/ccivil_03/_ato2004-2006/2004/lei/110.861.htm>. Acesso em: 10 abr. 2015.

BRASIL. Lei $n^{\circ}$ 11.196, de 21 de novembro de 2005. Institui o Regime Especial de Tributação para a Plataforma de Exportação de Serviços de Tecnologia da Informação REPES, o Regime Especial de Aquisição de Bens de Capital para Empresas Exportadoras RECAP e o Programa de Inclusão Digital. 2005. Disponível em:

$<$ http://www.planalto.gov.br/ccivil_03/_ato2004-2006/2005/lei/111196.htm>. Acesso em: 10 abr. 2015.

BRASIL. Lei ${ }^{\circ}$ 9.394, de 20 de dezembro de 1996. Estabelece as diretrizes e bases da educação nacional. 1996. Disponível em:

<http://www.planalto.gov.br/ccivil_03/LEIS/L9394.htm>. Acesso em: 10 abr. 2015.

BRASIL. Ministério da Educação. Qual é a diferença entre faculdades, centros universitários e universidades? 2016. Disponível em:

$<$ http://portal.mec.gov.br/component/content/article?id=116:qual-e-a-diferenca-entrefaculdades-centros-universitarios-e-universidades>. Acesso em: 01 fev. 2016.

BROOKES, B. C. The foundations of information science. Part I. Philosophical aspect. Journal of Information Science, n. 2, p. 125-133, 1980.

BUCKLAND, Michael K. Information as thing. Journal of the American Society of Information Science, v. 42, n. 5, p. 351-360, 1991.

BUFREM, L. S.; SORRIBAS, T. V. Práticas de leitura em meio eletrônico. ETD, v. 11, n. 1, p. 298-326, jul./dez. 2009. Disponível em: <http://bogliolo.eci.ufmg.br>. Acesso em: 30 nov. 2015. 
BUSH, Vannevar. As we may think. Athantic Monthly, v. 176, n. 11, p. 101-108, 1945. Disponível em: <http://www.theathantic.com/doc/194507/bush>. Acesso em: 30 mar. 2015.

CARRENHO, Carlo. Estimada em 0,29 por cento a participação de e-books no mercado brasileiro em 2012. Tipos digitais: o futuro digital do mercado editorial. Disponível em: $<$ http://www.tiposdigitais.com/2013/08/participação-de-e-books-no-mercado-brasileiro-em2012.html $>$. Acesso em: 20 ago. 2013.

CHARTIER, Roger. Aventura do livro: do leitor ao navegador; conversação com Jean Lebrun. São Paulo: Ed. Unesp, 1999.

CHEEK, Fern M.; HARTEL, Lynda J. The electronic book - beginnings to the presente. In: KAPLAN, Richard (Ed.). Building and managing e-book collections: a how-to-do-it manual for librarians. Atlanta: ALA Neal-Schuman, 2012. p. 3-12.

CONNAWAY, Lynn S.; WICHT, Heather. What happened to the e-book revolution?: the gradual integration of e-books into academic libraries. Journal of Electronic Publising, v. 10, n. 3, Fall/2007. Disponível em: <http://dx.doi.org/10.3998/3336451.0010.302>. Acesso em: 25 nov. 2015.

COSTA, Raquel P.; CUNHA, Murilo B. Modelo de negócios de livros eletrônicos para bibliotecas. Informação e Sociedade, João Pessoa, v. 25, n. 3, p. 7-19, set./dez. 2015. Disponível em: $<$ http://www.ies.ufpb.br/ojs/index.php/ies/article/view/26945>. Acesso em: 20 jan. 2016.

CRESWELL, John W. Projeto de pesquisa: métodos qualitativo, quantitativo e misto. 3. ed. Porto Alegre: Artmed, 2010.

CUNHA, Murilo B. Construindo o futuro: a biblioteca universitária brasileira em 2010. Ciência da Informação, Brasília, v. 29, n. 1, p. 71-89, jan./abr. 2000. Disponível em: $<$ http://www.scielo.br/pdf/ ci/v29n1/v29n1a8.pdf >. Acesso em: 20 ago. 2014.

A biblioteca universitária na encruzilhada. DataGramaZero - Revista de Ciência da Informação, v. 11, n. 6, dez/2010. Disponível em: $<$ http://www.dgz.org.br/dez10/F_I_art.htm>. Acesso em: 31 jul. 2014.

CUNHA, Murilo B.; CAVALCANTI, Cordélia R. de O. Dicionário de biblioteconomia e arquivologia. Brasilia: Briquet de Lemos, 2008.

CUNHA, Murilo B.; JESUS, Deise L. Produtos e serviços da web 2.0 no setor de referência das bibliotecas. Perspectivas em Ciência da Informação, v. 17, n. 1, p. 110-133, jan./mar. 2012. Disponível em: $<$ http://portaldeperiodicos.eci.ufmg.br/index.php/pci/article/view/885>. Acesso em: 12 maio 2015.

DAHLBERG, Ingetraut. Teoria do conceito. Ciência da Informação, Rio de Janeiro, v. 7, n. 2, p. 101-107, 1978. Disponível em:

<revista.ibict.br/index.php/ciinf/article/download/1680/1286>. Acesso em: 10 jun. 2015.

DARNTON, Robert. A questão dos livros: passado, presente e futuro. São Paulo: Companhia das Letras, 2010. 
DIAS, G. A.; VIEIRA, A. A. N.; SILVA, A. L. de A. Em busca de uma definição para o livro eletrônico: o conteúdo informacional e o suporte físico como elementos indissociáveis. In: ENCONTRO NACIONAL DE PESQUISA EM CIÊNCIA DA INFORMAÇÃO, 14., 2013, Florianópolis. Anais... Florianópolis: UFSC, 2013. Disponível em:

$<$ http://eprints.rclis.org/20904/1/Em\%20busca\%20de\%20uma\%20definição\%20para\%20o\%2 0livro\%20eletrônico.pdf>. Acesso em: 23 nov. 2015.

DIÓGENES, Fabiene C. B. Os novos papéis da biblioteca universitária brasileira. 2012. Tese (Doutorado em Ciência da Informação) - Universidade de Brasília, Faculdade de Ciência da Informação, Programa de Pós-Graduação em Ciência da Informação, 2012. Disponível em: $<$ http://repositorio.unb.br/bitstream/10482/12305/1/2012_FabieneCastelo BrancoDiogenes.pdf $>$. Acesso em: 10 jun. 2015.

DIRINGER, David. The book before printing: ancient, medieval and oriental. New York, N.Y.: Dover Publications, 1982.

DWAN, Pauline. Are books becoming extint in academic libraries? New Library World, v. 113, n. 1/2, p. 27-37, 2012. Disponível em: <http://dx.doi.org/10.1108/03074801211199022>. Acesso em: 24 nov. 2015.

DZIEKANIAK, Gisele V. et al. Considerações sobre o $e$-book: do hipertexto à preservação digital. Biblios, v. 1, n. 2, p. 83-99, jul./dez. 2010. Disponível em:

$<$ http://www.seer.furg.br/biblos/article/view/1899>. Acesso em: 10 fev. 2015.

DZIEKANIAK, Gisele V.; PACHECO, Roberto; KERN, Vinícius M. Revisitando a organização do conhecimento através dos tesauros, folksonomias e ontologias: aportes da engenharia do conhecimento. In: SILVA, Fabiano C. C.; SALES, Rodrigo de (Orgs.). Cenários da organização do conhecimento: linguagens documentárias em cena. Brasília: Thesaurus, 2011, p. 201-237.

EISENSTEIN, Elizabeth L. A revolução da cultura impressa: os primórdios da Europa moderna. São Paulo: Editora Ática, 1998.

FEBVRE, Lucien; MARTIN, Henri-Jean. O aparecimento do livro. São Paulo: Editora Unesp; Hucitec, 1992.

GALBRAITH, James. E-books on the internet. In: POLANKA, Sue (Org.). No shelf required: e-books in libraries. Chicago: American Library Association (ALA), 2011, p. 55-74.

GRAU, Isabel; ODDONE, Nanci E. Análise da literatura nacional sobre livro digital e eletrônico como subsídio para sua incorporação ao acervo das bibliotecas universitárias brasileiras. In: ENCONTRO NACIONAL DE PESQUISA EM CIÊNCIA DA INFORMAÇÃO (ENANCIB), 16., 2015, João Pessoa. Anais... João Pessoa: UFPB, 2015. Disponível em:

$<$ http://www.ufpb.br/evento/lti/ocs/index.php/enancib2015/enancib2015/paper/view/3102/116 2>. Acesso em: 03 fev. 2016.

GRAU, Isabel; ODDONE, Nanci E.; DOURADO, Stella. E-books, livros digitais ou livros eletrônicos? Um estudo terminológico. In: ENCONTRO NACIONAL DE PESQUISA EM 
CIÊNCIA DA INFORMAÇÃO - ENANCIB, 14., 2013., Santa Catarina. Anais... Santa Catarina: UFSC, 2013. Disponível em:

$<$ http://enancib.ibict.br/index.php/enancib/xivenancib/paper/viewFile/4364/3487>. Acesso em: 22 nov. 2015.

GUINCHAT, Claire; MENOU, Michel. Introdução geral às ciências e técnicas da informação e da documentação. 2. ed. corr. aum. Brasília: IBICT, 1994. Disponível em: $<$ http://livroaberto.ibict.br/handle/1/1007>. Acesso em: 10 jun. 2015.

INGRAM, Mathew. No, e-book sales are not falling, despite what publishers say. Fortune, n. 24, sept. 2015. Disponível em: <http://fortune.com/2015/09/24/ebook-sales/>. Acesso em: 03 fev. 2015.

KANT, Immanuel. Crítica da faculdade do juízo. 2. ed. Rio de Janeiro: Forense Universitária, 2008.

KAUARK, Fabiana; MANHÃES, Fernanda C.; MEDEIROS, Carlos H. Metodologia da pesquisa: guia prático. Itabuna: Via Litterarum, 2010.

KOTHARI, C. R. Research methodology: methods \& techniques. 2. ed. rev. Nova Deli: New Age International Publishers, 2004.

LABARRE, Albert. História do livro. São Paulo: Cultrix; [Brasília]: INL, 1981.

LARAIA, Roque B. Cultura: um conceito antropológico. 21. ed. Rio de Janeiro: Jorge Zahar Ed., 2007.

LE COADIC, Y. A Ciência da Informação. Brasília: Briquet de Lemos, 2004.

LÉVY, Pierre. As tecnologias da inteligência: o futuro do pensamento na era da informática. Rio de Janeiro: Ed. 34, 1993.

LYONS, Martyn. Livro: uma história viva. São Paulo: Senac, 2011.

MAGALHÃES, Carolina S. S. Seleção de coleções de livros digitais nas universidades públicas brasileiras. 2013. 159 f. Dissertação (Mestrado em Ciência da Informação) Instituto de Ciência da Informação, Universidade Federal da Bahia (UFBA), Salvador, 2013. Disponível em:

$<$ https://repositorio.ufba.br/ri/bitstream/ri/15021/1/Seleção\%20de\%20coleções\%20de\%20livr os\%20digitais_REPOSITORIO.pdf>. Acesso em: 22 nov. 2015.

MANGUEL, Alberto. Uma história da leitura. São Paulo: Companhia das Letras, 1997.

McGARRY, Kevin. O contexto dinâmico da informação. Brasília: Briquet de Lemos/Livros, 1999.

McNEELY, Ian F.; WOLVERTON, Lisa. A reinvenção do conhecimento: de Alexandria à internet. Rio de Janeiro: Record, 2013.

MEY, Eliane S. A.; SILVEIRA, Naira C. Catalogação no plural. Brasília: Briquet de Lemos, 
2009.

PAIVA, Ana Paula Mathias. A aventura do livro experimental. São Paulo: EdUsp; Belo Horizonte: Autêntica, 2010.

PASSOS, Jeane R.; OLIVEIRA, Rosa M. V. B.; VIEIRA, Simone M. P. Processo de avaliação do MEC para a educação superior e os $e$-Books. In: SEMINÁRIO NACIONAL DE BIBLIOTECAS UNIVERSITÁRIAS, 16., 2010, Rio de Janeiro. Anais... Rio de Janeiro: UFRJ, 2010. Disponível em: <http://www.sibi.ufrj.br/snbu2010/pdfs/orais/ final_259.pdf>. Acesso em: 20 jun. 2015.

PESQUISA bibliotecas e leitura digital no Brasil: análise sobre aderência e impactos sobre a leitura. Observatório do Livro e da Leitura, 2014. Disponível em: <http://biblioo.info/wpcontent/uploads/2014/04/Pesquisa-Bibliotecas-e-Leitura-Digital-no-Brasil.pdf> . Acesso em: 10 jun. 2014.

PETTICREW, Mark; ROBERTS, Helen. Systematic reviews in the social sciences: a practical guide. Oxford: Blackwell Publishing, 2006.

POLANKA, Sue (Ed.). No shelf required 2: use and management of electronic books. Chicago: American Library Association, 2012.

PROCÓPIO, Ednei. O livro na era digital: o mercado editorial e as mídias digitais. São Paulo: Giz Editorial, 2010.

PWC. Outlook insights: an analysis of the global entertainment and media outlook 20142018. Book publishing. 2014. Disponível em: <http://www.pwc.com/gx/en/globalentertainment-media-outlook/segment-insights/consumer-and-educational-bookpublishing.jhtml>. Acesso em: 15 mar. 2015.

REITZ, Joan M. Online dictionary for library and Information Science. 2016. Disponível em: $<$ http://www.abc-clio.com/ODLIS/odlis_e.aspx\#electronicbook>. Acesso em: 10 jan. 2016.

RIBEIRO, Antonia M. C. M. Catalogação de recursos bibliográficos: AACR2 em MARC21. 3. ed. rev e ampl. Brasília: Ed. do Autor, 2006.

RODRIGUES, Maria Fernanda. Câmara discute definições para e-books. O Estado de São Paulo, São Paulo, maio 2014. Disponível em:

$<$ http://www.estadao.com.br/noticias/impresso,camara-discute-definicoes-para-ebooks, $1163299,0 . \mathrm{htm}>$. Acesso em: 10 fev. 2015.

ROSS, L.; SENNYEY, P. The library is dead, long live the library! Journal of Academic Librarianship, v. 34, n. 2, p. 145-152, 2008.

SÁ, Nelson de. Mercado de livros eletrônicos dá sinais de estagnação. Folha de São Paulo, dez. 2015. Disponível em: <http://www1.folha.uol.com.br/mercado/2015/12/1715246mercado-de-livros-eletronicos-da-sinais-de-estagnacao.shtml >. Acesso em: 20 dez. 2015.

SANTOS, J. S.; SENA, R. L.; ODDONE, N. O impacto dos livros digitais sobre as bibliotecas universitárias da UFBA. In: ENCONTRO NACIONAL DE ENSINO E 
PESQUISA EM INFORMAÇÃO, 10., 2011, Salvador. Anais... Salvador: UFBA, 2011. Disponível em:

$<$ http://www.cinform2011.ici.ufba.br/modulos/submissao/Upload/37565.pdf $>$. Acesso em: 23 nov. 2015.

SEHN, Thais C. M. As possíveis configurações do livro nos suportes digitais. 2014. 265 f. Dissertação (Mestrado) - Programa de Pós-Graduação em Comunicação e Informação, Faculdade de Biblioteconomia e Comunicação, Universidade Federal do Rio Grande do Sul. Porto Alegre, 2013. Disponível em: <http://hdl.handle.net/10183/97246>. Acesso em: 25 nov. 2015.

SEPTEMBER 2015 Author Earnings report. Authors Earnings, sept. 2015. Disponível em: $<$ http://authorearnings.com/report/september-2015-author-earnings-report/>. Acesso em: 10 dez. 2015.

SERAKAN, Uma. Research methods for business: a skill-building approach. 4. ed. Nova Iorque: John Wiley \& Sons, 2003.

SERRA, Liliana G. Livro digital e bibliotecas. Rio de Janeiro: FGV, 2014. (FGV de Bolso, $36)$.

SERRA, Liliana G.; SILVA, José Fernando M. Impacto dos e-books em bibliotecas e o modelo de assinatura de publicações. In: CONGRESSO BRASILEIRO DE BIBLIOTECONOMIA E DOCUMENTAÇÃO, 25., 2013, Florianópolis. Anais... Florianópolis: Febab, 2013, p. 2132 - 2145. Disponível em: $<$ http://portal.febab.org.br/anais/article/view/1408>. Acesso em: 25 nov. 2015.

TAMMARO, Anna M.; SALARELLI, Alberto. A biblioteca digital. Brasília, DF: Briquet de Lemos, 2008.

TARAPANOFF, Kira. A biblioteca universitária vista como uma organização social. Estudos avançados em Biblioteconomia e Ciência Informação, Brasília, v. 1, n. 01, p. 73-92, 1982. Disponível em:

$<$ http://www.brapci.inf.br/_repositorio/2011/06/pdf_f220a35953_0017357.pdf >. Acesso em: 23 nov. 2015.

VASILEIOU, M.; ROWLEY, J.; HARTLEY, R. Perspectives on the future of e-books in libraries in universities. JoLIS, v. 44, n. 4, p. 217-226, fev. 2012. Disponível em:

$<$ http://lis.sagepub.com/content/44/4/217.abstract>. Acesso em: 20 abr. 2014.

VASSILOU, M; ROWLEY, J. Progressing the definition of "e-book". Library Hi Tech, v. 26, n. 3, p. 355-368, 2008. Disponível em:

$<$ http://www.emeraldinsight.com/doi/abs/10.1108/073788308 10903292>. Acesso em: 20 abr. 2014.

VELASCO, J. O. O uso do livro eletrônico na prática científica. Dissertação (Mestrado em Ciência da Informação) - PPGCI, Universidade Federal da Bahia, Salvador, 2008. Disponível em: <https://repositorio.ufba.br/ri/handle/ri/7948>. Acesso em: 25 nov. 2015. 
WALTERS, William H. E-books in academic libraries: challenges for acquisition and collection management. Libraries and the Academy, v. 13, n. 2, p.187-211, 2013. Disponível em:

$<$ https://www.press.jhu.edu/journals/portal_libraries_and_the_academy/portal_pre_print/curre nt/articles/13.2walters.pdf>. Acesso em: 20 abr. 2015.

WEITZEL, Simone R. Critérios para seleção de documentos eletrônicos na Internet. In: CONGRESSO BRASILEIRO DE BIBLIOTECONOMIA E DOCUMENTAÇÃO, 19., Porto Alegre, 2000. Anais... Porto Alegre: PUCRS, 2000. 


\title{
8 APÊNDICE
}

\subsection{Apêndice A - Questionário do pré-teste}

\author{
Universidade de Brasília - UnB \\ Faculdade de Ciência da Informação - FCI \\ Programa de Pós-Graduação em Ciência da Informação - PPGCInf \\ Mestrado em Ciência da Informação
}

Prezado(a) participante,

O questionário que segue foi concebido para fomentar a pesquisa de mestrado que possui o objetivo geral de analisar como o uso de livros eletrônicos é feito nas coleções das bibliotecas universitárias do Distrito Federal. Esse questionário possui 21 perguntas, das quais 16 são do tipo fechada e 5 do tipo aberta. A informação que você fornecerá irá nos ajudar a encontrar indicadores quantitativos e qualitativos do uso do livro eletrônico nesse tipo de biblioteca. Pedimos a gentileza de responder às perguntas de forma franca, visto que você é o principal profissional que poderá nos suprir de informações corretas sobre o tema. Sua identidade será mantida em sigilo e suas respostas utilizadas para fins apenas desta pesquisa e dos trabalhos dela resultantes. Um resumo dos resultados será enviado a você depois de analisados os dados.

Muito obrigada pelo seu tempo e colaboração para promover esse esforço de investigação científica.

Cordialmente,

Ana Flávia Lucas de Faria Kama, Mestranda em Ciência da Informação.

Professora Doutora Miriam Paula Manini, Orientadora.

\section{Seção 01: Sobre você}

Por favor, circule os números que representam a resposta mais apropriada às suas características: 

a) Sua idade (anos)
b) Sua formação
c) Seu gênero
$120-30$
acadêmica
1 Feminino
$230-40$
1 Graduação
2 Masculino
$340-50$
2 Pós-gradução lato sensu
$450-60$
3 Mestrado
5 Mais de 60
5 Doutorado
6 Pós-doutorado

\section{Seção 02: Bibliotecário - Livros eletrônicos/e-books}

Questão 01: O que é um livro eletrônico na sua visão?

Questão 02: Um livro impresso digitalizado é um livro eletrônico?

( ) $\operatorname{Sim}($ ) Não

Questão 03: Marque um X em cada formato de livro eletrônico que você conhece:

( ) PDF ( ) ePub ( ) Mobi ( ) AZW ( ) AF8 ( ) HTML ( ) Nenhum desses

Questão 04: Um livro em formato PDF (Portable Document Format) é um livro eletrônico para você?

( ) $\operatorname{Sim}$ ( ) Não ( ) Depende:

Questão 05: Você já leu um livro eletrônico?

( ) $\operatorname{Sim}$ ( ) Não

Questão 06: Você já adquiriu um livro eletrônico em uma loja/editora/livraria?

( ) $\operatorname{Sim}$ ( ) Não 


\section{Seção 03: Sobre a biblioteca em que você trabalha}

Questão 01: Qual o nome da faculdade/universidade da qual faz parte sua biblioteca?

Questão 02: Qual o nome da sua biblioteca?

Questão 03: A sua biblioteca disponibiliza base de dados de conteúdo digital? (Exemplo: Repositório institucional, Base de dados de artigos científicos, Coleções digitais etc.)

( ) $\operatorname{Sim}$ ( ) Não

Questão 04: Se a sua biblioteca possui bases de dados de conteúdo digital, são disponibilizados livros eletrônicos nelas?

( ) $\operatorname{Sim}($ ) Não

Questão 05: Se não há disponibilização de livros eletrônicos na sua biblioteca, existe alguma previsão para que esse serviço seja implementado?

( ) $\operatorname{Sim}($ ) Não

\section{Seção 04: Biblioteca - Livros eletrônicos/e-books}

Questão 01: Sua biblioteca definiu em alguma política ou norma interna o que é um livro eletrônico?

( ) $\operatorname{Sim}($ ) Não

Questão 02: Caso sua biblioteca possua uma definição formal de livro eletrônico, qual é ela? 
Questão 03: Na sua visão, o que é livro eletrônico para a sua biblioteca?

Observação: A próxima seção só precisa ser respondida caso sua biblioteca tenha uma coleção de livros eletrônicos.

\section{Seção 05: Sobre a coleção de livros eletrônicos da sua biblioteca}

Questão 01: Há quanto tempo sua biblioteca possui uma coleção de livros eletrônicos?

( ) menos de 1 ano ( ) 1 a 2 anos ( ) 2 a 4 anos ( ) 4 a 6 anos ( ) mais de 6 anos

Questão 02: Os livros eletrônicos que existem na sua biblioteca estão disponíveis em plataformas/sites/sistemas que não sejam o da própria biblioteca? (Exemplo: ProQuest, ebray, Dot.Lib, EBSCO, Pearson, JSTOR Books, Saraiva etc.)

( ) $\operatorname{Sim}$ ( ) Não

Questão 03: Existe algum livro eletrônico que esteja hospedado/armazenado em um sistema/plataforma próprio da sua biblioteca? (Exemplo: Repositório institucional, Biblioteca Digital, OPAC etc.)

( ) $\operatorname{Sim}$ ( ) Não

Questão 04: Na sua opinião, qual é o nível de uso da coleção de livros eletrônicos existente na sua biblioteca:

( ) muito baixo ( ) baixo ( ) médio 


\title{
8.2 Apêndice B - Questionário
}

\author{
Universidade de Brasília - UnB \\ Faculdade de Ciência da Informação - FCI \\ Programa de Pós-Graduação em Ciência da Informação - PPGCInf \\ Mestrado em Ciência da Informação
}

Prezado(a) participante,

O questionário que segue foi concebido para fomentar pesquisa de mestrado que possui o objetivo geral de analisar como o uso de livros eletrônicos é feito nas coleções das bibliotecas universitárias do Distrito Federal. São 42 perguntas, das quais 39 são do tipo fechada e 03 são do tipo aberta. A informação que você fornecerá irá nos ajudar a encontrar indicadores quantitativos e qualitativos do uso do livro eletrônico nesse tipo de biblioteca. Pedimos a gentileza de responder às perguntas de forma franca, visto que você é o principal profissional que poderá nos suprir de informações corretas sobre o tema; certamente tais informações reverterão utilidade para o seu local de trabalho, ao final da pesquisa. Sua identidade será mantida em sigilo e suas respostas utilizadas para fins apenas da referida pesquisa e dos trabalhos dela resultantes. Um resumo dos resultados será enviado a você após a análise dos dados coletados.

Agradecemos seu tempo, dedicação e colaboração para promover esse esforço de investigação científica.

Cordialmente,

Ana Flávia Lucas de Faria Kama, Mestranda em Ciência da Informação

Professora Doutora Miriam Paula Manini, Orientadora

\section{Seção 01: Sobre você}

Por favor, circule os números que representam a resposta mais apropriada às suas características: 

a) Sua idade (anos)
b) Sua formação acadêmica
c) Seu gênero
$120-30$
1 Graduação
1 Feminino
$230-40$
2 Pós-gradução lato sensu
2 Masculino
$340-50$
3 Mestrado
$450-60$
5 Doutorado
5 Mais de 60
6 Pós-doutorado

\section{Seção 02: Bibliotecário - Livros eletrônicos/e-books}

Questão 01: O que é um livro eletrônico, para você?

Questão 02: Um livro impresso digitalizado é um livro eletrônico?
( ) $\operatorname{Sim}$
( ) Não

Questão 03: Marque um $X$ em cada formato de livro eletrônico que você conhece:
( ) PDF
( ) ePub
( ) Mobi
( ) AZW
( ) AF8
( ) HTML
( ) Nenhum desses

Questão 04: Para você, há diferença entre livro eletrônico e livro digital?
( ) $\operatorname{Sim}$
( ) Não ( )
Depende:

Questão 05: Você já leu um livro eletrônico?
( ) $\mathrm{Sim}$
( ) Não

Questão 06: Você já adquiriu um livro eletrônico em uma loja/editora/livraria?
( ) $\mathrm{Sim}$
( ) Não 
Questão 07: Você já apresentou ou participou de algum grupo de trabalho no Seminário Nacional de Bibliotecas Universitárias (SNBU) ou no Congresso Brasileiro de Biblioteconomia ou Documentação (CBBD) relacionado ao livro eletrônico?
( ) $\operatorname{Sim}$
( ) Não

Questão 08: Caso você participe de algum grupo de trabalho ou fórum de discussão relacionado a livros eletrônicos, conte-nos o nome desse grupo/fórum:

\section{Seção 03: Sobre a biblioteca em que você trabalha}

Questão 01: Sua biblioteca é:

( ) pública ( ) privada

Questão 02: Indique o tamanho do acervo físico de sua biblioteca:

( ) De 1.000 a 50.000 itens

( ) De 50.000 a 100.000 itens

( ) De 100.000 a 500.000 itens

( ) Mais de 500.000 itens

Questão 03: O acervo de sua biblioteca é representativo de qual(is) área(s) do conhecimento (de acordo com a Tabela de Áreas de Conhecimento/Avaliação da CAPES)?

( ) Ciências Exatas e da Terra

( ) Ciências Biológicas

( ) Engenharias

( ) Ciências da Saúde

( ) Ciências Agrárias

( ) Ciências Sociais Aplicadas

( ) Ciências Humanas

( ) Línguas, Letras e Artes

( ) Multidisciplinar 
Questão 04: Qual o sistema de informação automatizado que é utilizado em sua biblioteca?
( ) Pergamum
( ) Sophia
( ) Aleph
( ) Alexandria
( ) OrtoDocs
( ) Siabi
( ) Gnuteca
( ) BibLivre
( ) Koha
( ) CDS/ISIS
( ) Outro:

Questão 05: Quantos terminais de consulta com acesso a um sistema de informação automatizado existem em sua biblioteca?
( ) Nenhum
( ) 01 terminal
( ) De 01 a 03 terminais
( ) De 03 a 10 terminais
( ) Mais de 10 terminais

Questão 06: Sua biblioteca atende quantos usuários por mês?
( ) De 30 a 100 usuários
( ) De 100 a 300 usuários
( ) De 300 a 500 usuários
( ) De 500 a 1.000 usuários
( ) De 1.000 a 3.000 usuários
( ) Mais de 3.000 usuários

Questão 07: Como é o acesso às instalações da sua biblioteca?
( ) Livre para qualquer usuário
( ) Restrito a usuários cadastrados
( ) Restrito a usuários estudantes ou funcionários da instituição 
( ) Outro:

Questão 08: Como é o acesso ao acervo físico da sua biblioteca?

( ) Livre para qualquer usuário

( ) Restrito a usuários cadastrados

( ) Restrito a usuários estudantes ou funcionários da instituição

( ) Outro:

Questão 09: Sua biblioteca disponibiliza base de dados de conteúdo digital? (Exemplo: Repositório institucional, Base de dados de artigos científicos, Coleções digitais etc.)
( ) $\operatorname{Sim}$
( ) Não

Questão 10: Caso positivo, são disponibilizados livros eletrônicos nestas bases de conteúdo digital?
( ) $\operatorname{Sim}$
( ) Não

Questão 11: Se não há disponibilização de livros eletrônicos na sua biblioteca, existe alguma previsão para que esse serviço seja implementado?
( ) $\operatorname{Sim}$
( ) Não

Questão 12: Caso haja acervo digital ou livros eletrônicos em sua biblioteca, como é feito o acesso a ele(s)?

( ) Livre para qualquer usuário

( ) Restrito a usuários cadastrados

( ) Restrito a usuários estudantes ou funcionários da instituição

( ) Não há acervo digital na minha biblioteca

( ) Outro:

Questão 13: Caso haja acervo digital ou livros eletrônicos em sua biblioteca, quantos terminais de consulta com acesso a esse acervo existem disponíveis ao usuário?

( ) Nenhum

( ) 01 terminal

( ) De 01 a 03 terminais

( ) De 03 a 10 terminais 
( ) Mais de 10 terminais

Observação: Só responda à próxima seção caso sua biblioteca tenha uma coleção de livros eletrônicos.

\section{Seção 04: Sobre a coleção de livros eletrônicos da sua biblioteca}

Questão 01: Há quanto tempo sua biblioteca possui uma coleção de livros eletrônicos?

( ) menos de 1 ano ( ) 1 a 2 anos ( ) 2 a 4 anos ( ) 4 a 6 anos

( ) mais de 6 anos

Questão 02: Sua biblioteca disponibiliza livros eletrônicos com quais tipos de acesso?

( ) Acesso Aberto

( ) Livros com limites de acesso (DRM - Digital Rights Management ou Gestão de direitos digitais)

( ) Outro:

Questão 03: Existe algum livro eletrônico que esteja hospedado/armazenado em um sistema/plataforma próprio da sua biblioteca? (Exemplo: Repositório institucional, Biblioteca Digital, OPAC etc.)

( ) $\operatorname{Sim}$ ( ) Não

Questão 04: Os livros eletrônicos que existem em sua biblioteca estão disponíveis em plataformas, sites ou sistemas que não sejam o da própria biblioteca? (Exemplo: ProQuest, ebray, Dot.Lib, EBSCO, Pearson, JSTOR Books, Minha Biblioteca, Domínio Público, Livro Aberto etc.)

( ) Sim ( ) Não

Questão 05: Caso sua biblioteca disponibilize seus livros eletrônicos de acesso aberto em bases de dados, plataformas, sites ou sistemas que não sejam os da própria biblioteca, quais são eles?

( ) Não disponibiliza 
( ) Domínio Público

( ) SciELO Livros

( ) Brasiliana USP

( ) Livro Aberto (IBICT)

( ) Bookboon.com

( ) DOAB (Directory of Open Access Books)

( ) Free Tech Books

( ) OAPEN (Open Access Publishing)

( ) Project Gutenberg

( ) Outros:

Questão 06: Caso sua biblioteca disponibilize seus livros eletrônicos de acesso restrito em bases de dados, plataformas, sites ou sistemas que não sejam os da própria biblioteca, quais são eles?

( ) Não disponibiliza

( ) Dot.Lib

( ) EBSCO (NetLibry ou eBooks on EBSCOHost)

( ) Pearson (Biblioteca Virtual Acadêmica Pearson)

( ) ProQuest (ebrary)

( ) Minha Biblioteca

( ) Portal Capes

( ) Cambrigde University Press

( ) Elsevier

( ) IEEE

( ) Oxford University Press

( ) Palgrave-MacMillan

( ) Royal Society of Chemistry

( ) Springer

( ) Wiley-Blackwell

( ) JSTOR Books

( ) Overdrive

( ) Ingram (myiLibrary)

( ) Skillsoft (Books 24x7)

( ) Baker \& Taylor/YBP Library Services 
( ) Swets

( ) Outros:

Questão 07: Caso sua biblioteca disponibilize livros eletrônicos de acesso restrito, como é realizado o empréstimo deles?

( ) Não é feito empréstimo de livros eletrônicos

( ) Download

( ) Acesso somente pela base de dados/sem download

( ) Outro:

Questão 08: Quais são as tipologias e formatos de livros eletrônicos que sua biblioteca disponibiliza aos usuários?
( ) PDF
( ) ePub
( ) Mobi
( ) AZW
( ) AF8
( ) HTML
( ) TXT
( ) DOC
( ) Outro:

Questão 09: No processo de seleção dos livros eletrônicos de sua biblioteca, quais são os critérios que mais são levados em conta?

( ) Custo

( ) Tipo de acesso (acesso restrito ou aberto)

( ) Limite de empréstimo ou de download de cada título

( ) Forma de aquisição (por assinatura, perpétuo, por demanda etc.)

( ) Relevância do título para a coleção e para os usuários

( ) Formato do livro eletrônico (PDF, ePub, Mobi, HTML, AZW, HTML etc.)

( ) Forma de preservação do livro eletrônico

( ) Atualidade do título

( ) Outros: 
Questão 10: Como os livros eletrônicos da sua biblioteca são catalogados?

( ) Não são catalogados

( ) São catalogados da mesma maneira que os livros impressos

( ) São catalogados de uma forma específica para livros eletrônicos

( ) Outro(s):

Questão 11: Existe algum orçamento específico destinado a aquisição de livros eletrônicos em sua biblioteca?
( ) $\operatorname{Sim}$
( ) Não
( ) Outro:

Questão 12: Como é feita a divulgação do acervo de livros eletrônicos em sua biblioteca?

( ) Não é feita

( ) Catálogo online da biblioteca

( ) Site da biblioteca

( ) Folhetos impressos

( ) E-mails de divulgação

( ) Por meio da referência

( ) Outro(s):

Questão 13: Existe alguma política de preservação digital para os livros eletrônicos de sua biblioteca?
( ) $\operatorname{Sim}$
( ) Não

Questão 14: Caso exista alguma política ou ação de preservação digital de livros eletrônicos em sua biblioteca, qual seria?

( ) Não há política ou ação de preservação digital

( ) Backups

( ) Participação em redes de preservação digital (Exemplo: Rede Caririana/IBICT)

( ) Uso de softwares de preservação digital (Exemplo: LOCKSS)

( ) Conversão/atualização de formatos e softwares

( ) Emulação de softwares antigos/obsoletos

( ) Formalização - uso de metadados de preservação (OAIS) 
( ) Outro(s):

Questão 15: Qual é o nível de uso da coleção de livros eletrônicos existente na sua biblioteca (usuários externos):

( ) até $10 \%$ dos usuários ( ) de $10 \%$ a $20 \%$ dos usuários （） de $20 \%$ a $50 \%$ dos usuários ( ) de 50\% a 70\% dos usuários ( ) acima de 70\% dos usuários

Questão 16: Quais são as maiores dificuldades encontradas por sua biblioteca na formação do acervo de livros eletrônicos?

( ) Orçamento

( ) Preço dos livros eletrônicos

( ) Formas de aquisição (por assinatura, perpétuo, por demanda etc.)

( ) Poucos títulos relevantes no mercado

( ) Limites de acesso (restrições de direitos autorais/DRM, impressão, empréstimos, download)

( ) Falta de interesse dos usuários

( ) Problemas com os modelos de negócios disponíveis no mercado

( ) Impossibilidade de escolher/adquirir título por título

( ) Dificuldades na preservação

( ) Ausência de uma política específica para esse tipo de item

( ) Outro(s):

Questão 17: Você acha que os livros eletrônicos são relevantes para a formação dos usuários da sua biblioteca?
( ) $\operatorname{Sim}$
( ) Não
( ) Não sei

Questão 18: Na sua opinião, qual é a importância dos livros eletrônicos em uma biblioteca universitária? 